DOE/EE-0159

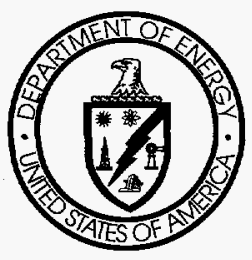

\title{
Advanced Automotive Tecfinologies Annual Report to Congress Fiscal Year 1996
}

\section{RECEIVSD \\ MAY 07.1998}
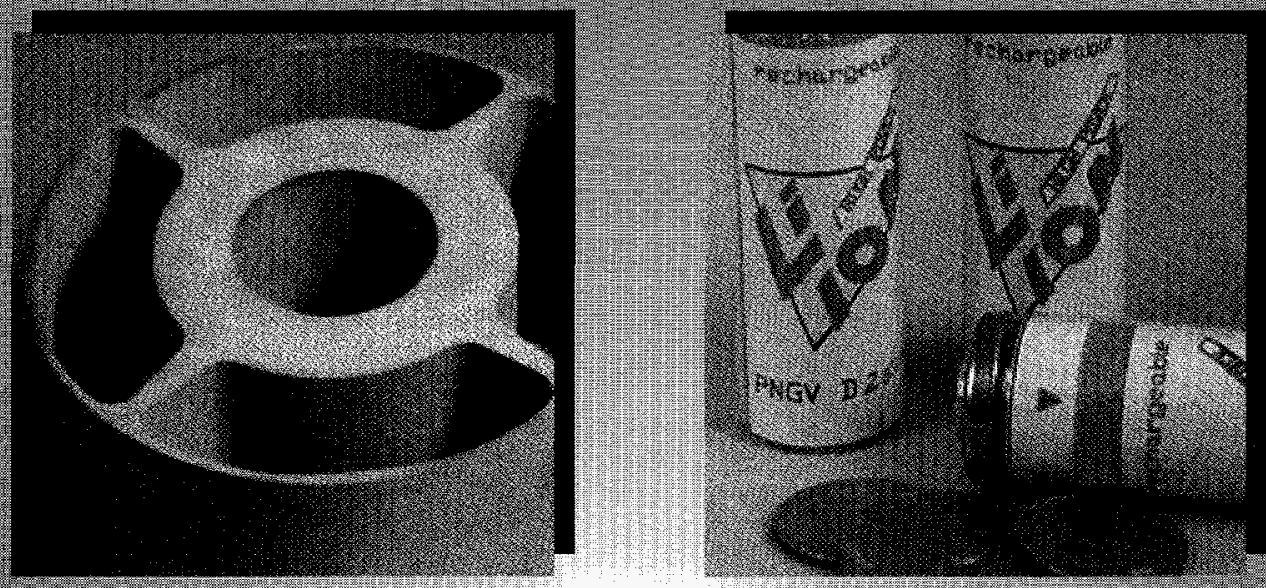

OS TI
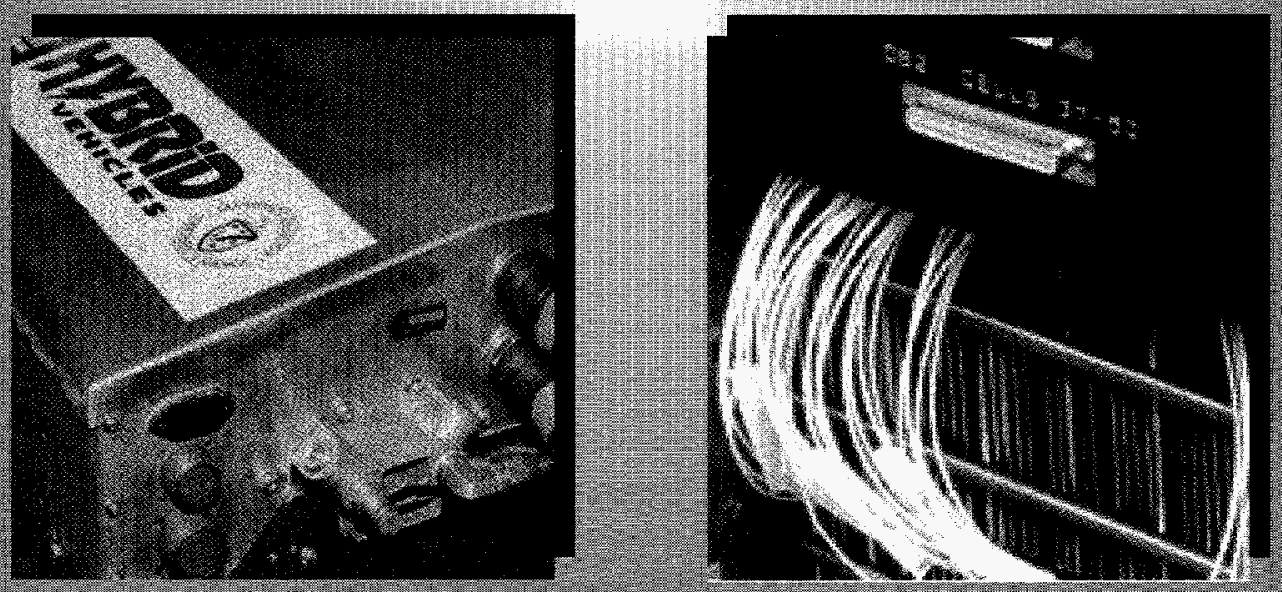

Oftee of Advanced Antomotive Tecfinofogies Offee of Trunsportation Tecinofogies Energy Efficiency and Renewable Energy 


\section{To obtain a copy of this report or to be added to the mailing list for future annual reports, please send your request to:}

\section{The U.S. Department of Energy}

Office of Advanced Automotive Technologies

EE-32 (Annual Report)

1000 Independence Avenue, SW

Washington, DC 20585-0121

Please specify: Advanced Automotive Technologies Annual Report to Congress and indicate if you are requesting a copy of the Fiscal Year 1996 report and/or want to be added to the mailing list for future editions.

Also available to DOE and DOE Contractors from the Office of Scientific and Technical Information, P.O. Box 62, Oak Ridge, TN 37831; prices available from (423) 576-8401.

Also available to the public from the U.S. Department of Commerce, Technology Administration, National Technical Information Service, Springfield, VA 22161, (703) 487-4650. 


\title{
Advanced Automotive Technologies
}

\author{
Annual Report to Congress
}

Fiscal Year 1996

U.S. Department of Energy

Assistant Secretary, Energy Efficiency

and Renewable Energy

Office of Transportation Technologies

Washington, DC 20585

MASTER

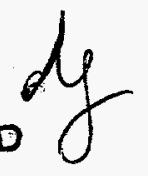




\section{DISCLAIMER}

Portions of this document may be illegible electronic image products. Images are produced from the best available original document. 


\section{TABLE OF CONTENTS}

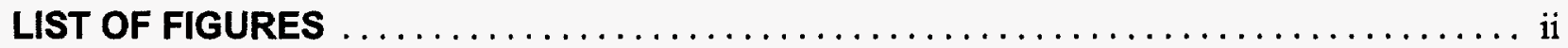

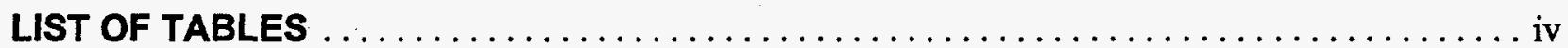

PREFACE $\ldots \ldots \ldots \ldots \ldots \ldots \ldots \ldots \ldots \ldots \ldots \ldots \ldots \ldots \ldots \ldots \ldots \ldots \ldots \ldots$

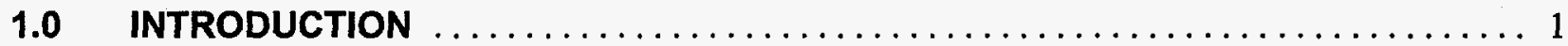

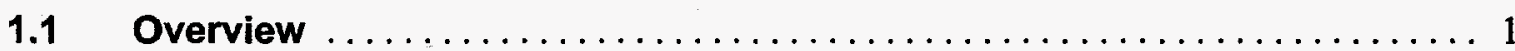

1.2 Status of Conventional Powertrain Technology $\ldots \ldots \ldots \ldots \ldots \ldots \ldots$

2.0 ADVANCED AUTOMOTIVE TECHNOLOGIES

RESEARCH AND DEVELOPMENT $\ldots \ldots \ldots \ldots \ldots \ldots \ldots \ldots \ldots \ldots \ldots \ldots \ldots \ldots$

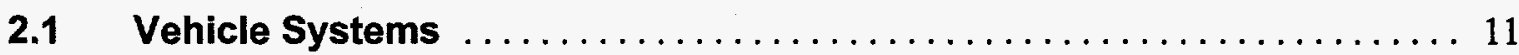

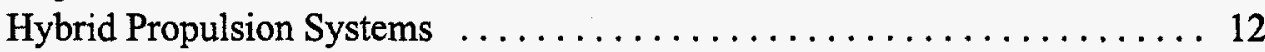

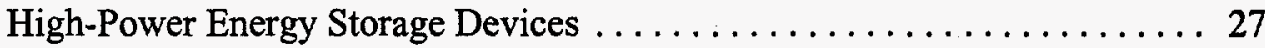

Power Electronics and Electric Machines $\ldots \ldots \ldots \ldots \ldots \ldots \ldots \ldots$

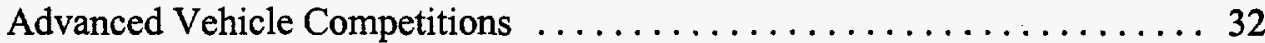

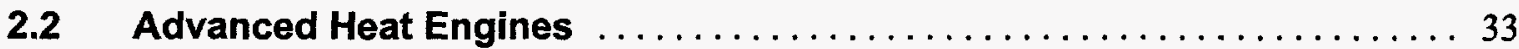

Gas Turbine Hybrid Power Unit $\ldots \ldots \ldots \ldots \ldots \ldots \ldots \ldots \ldots \ldots \ldots \ldots$

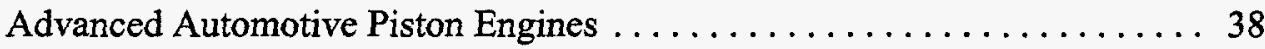

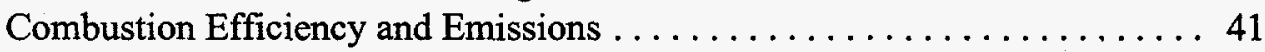

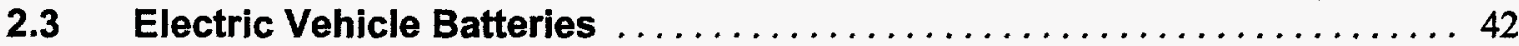

United States Advanced Battery Consortium . . . . . . . . . . . . . . 43

Exploratory Technology Research. ................... 46

Electric Vehicle Readiness . . . . . . . . . . . . . . . . . . . . . . . . 48

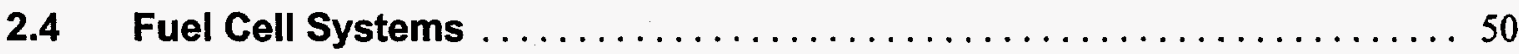

Systems Technology Development $\ldots \ldots \ldots \ldots \ldots \ldots \ldots \ldots \ldots \ldots \ldots$

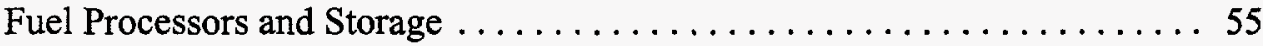

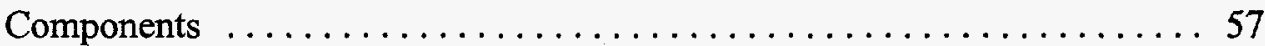

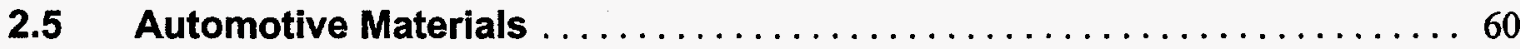

Lightweight Body, Chassis, and Engine Materials ............6 60

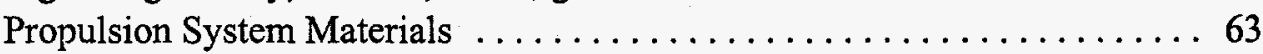

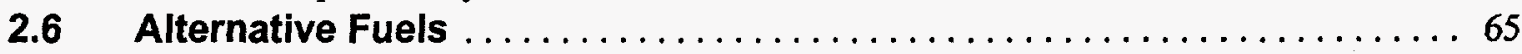

Light-Duty Vehicle Alternative Fuels $\ldots \ldots \ldots \ldots \ldots \ldots \ldots \ldots \ldots 6$

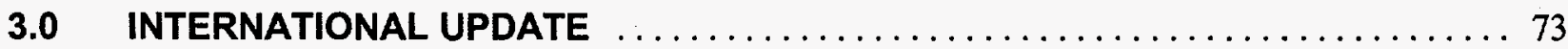

4.0 CONCLUSION $\ldots \ldots \ldots \ldots \ldots \ldots \ldots \ldots \ldots \ldots \ldots \ldots \ldots \ldots \ldots \ldots \ldots \ldots$

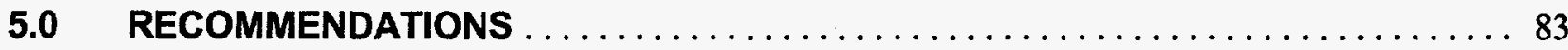

\section{APPENDICES}

Appendix A Legislative Requirements and Compliance $\ldots \ldots \ldots \ldots \ldots \ldots$ A-1

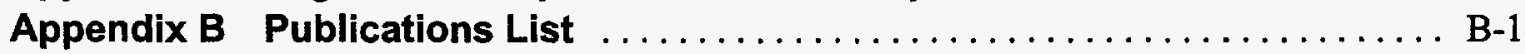

Appendix $\mathbf{C} \quad$ List of Abbreviations and Acronyms $\ldots \ldots \ldots \ldots \ldots \ldots \ldots, \mathrm{C}-1$ 


\section{LIST OF FIGURES}

Figure 1

Figure 2

Figure 3

Figure 4

Figure 5

Figure 6

Figure 7

Figure 8

Figure 9

Figure 10

Figure 11

Figure 12

Fígure 13

Figure 14

Figure 15

Figure 16

Figure 17

Figure 18

Figure 19

Figure 20

Figure 21

Figure 22

Figure 23

Figure 24

Figure 25

Figure 26
Office of Advanced Automotive Technologies Organization

Technologies Under Research and Development to Achieve

OAAT Goal and Objectives ...

Passenger Car Fuel Economy and Inertia Weight

5

Increasing Highway Vehicle Miles Traveled $\ldots \ldots \ldots \ldots \ldots \ldots \ldots \ldots$

Transportation Contribution to Our Growing Dependence on Imported Oil . . . . . 6

Relative Highway Vehicle Emissions per Mile Traveled (Base 1970) . . . . . . . . 7

Schematic Diagrams of Typical Series and Parallel HEV Configurations . . . . . . 13

Electric Drive Unit

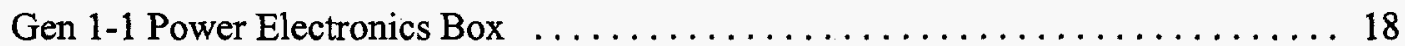

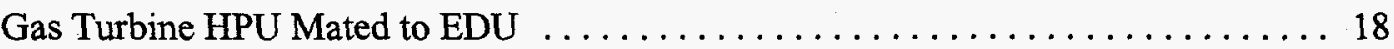

Gen 1-2 Stirling HPU Mated to EDU $\ldots \ldots \ldots \ldots \ldots \ldots \ldots \ldots \ldots \ldots \ldots \ldots$

Flywheel Energy Storage System Composite Rotor/Hub .............. 22

Teledyne Ryan Aeronautical Model 105 Turbo-Generator Mockup . . . . . . . . 22

Series and Parallel Mules Induction Motor Traction Drive $\ldots \ldots \ldots \ldots \ldots \ldots$

SAFT Lithium-Ion Cells Delivered to INEL for Testing . . . . . . . . . . . 29

Lawrence Technological University: 1996 FutureCar Challenge

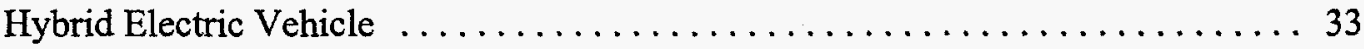

Ceramic Gas Turbine HPU: A Candidate for PNGV Hybrid Vehicles $\ldots \ldots \ldots \ldots 35$

CIDI Research Activities

Laser-Induced Fluorescence of Gasoline Films: Combustion Emissions

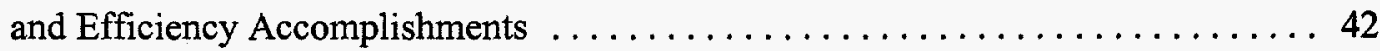

Ford's Conceptual Design for a Ground Up Zero-Emission Fuel Cell Vehicle . . . . 53

Phase I PEM Fuel Cell Stacks Developed for Ford by Mechanical

Technology, Inc., International Fuel Cells, and Energy Partners

Design-to-Cost Projections for AlliedSignal PEM Fuel Cell Fabricated

With Carbon-Coated or Conductive Plastic Bipolar Plates . . . . . . . . . . . . 55

Arthur D. Little $50-\mathrm{kW}$ Fuel Processor $\ldots \ldots \ldots \ldots \ldots \ldots \ldots \ldots \ldots \ldots \ldots$

The Argonne National Laboratory 10-kW Low-Temperature

Partial-Oxidation Reformer Under Laboratory Development . . . . . . . . . . . . 57

Laboratory-Scale Development of a Direct Methanol Fuel Cell at

Los Alamos National Laboratory . . . . . . . . . . . . . . . . . . . 59

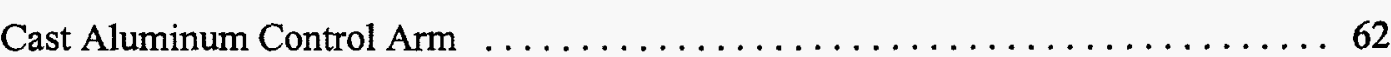


Figure 27 INEL Computational Fluid Dynamics Model of "Slurry Process"

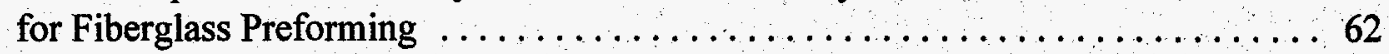

Figure $28 \quad$ ORNL Researchers Demonstrate the Gelcasting Process for Molding

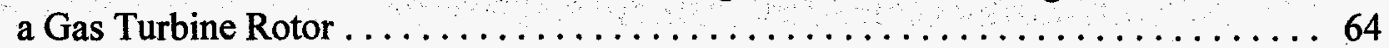

Figure $29 \quad$ Integrated Storage System CAD Assembly View $\ldots \ldots \ldots \ldots \ldots \ldots \ldots \ldots \ldots$

Figure $30 \quad$ Advanced Natural Gas Vehicle Design $\ldots \ldots \ldots \ldots \ldots \ldots \ldots \ldots \ldots \ldots \ldots$

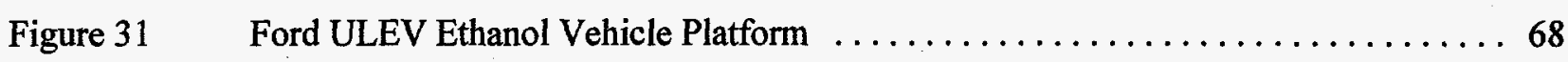

Figure $32 \quad$ ADL Compact Prototype Partial-Oxidation Reactor ................ 69

Figure $33 \quad$ Chrysler ULEV LPG Vehicle Platform $\ldots \ldots \ldots \ldots \ldots \ldots \ldots \ldots \ldots \ldots \ldots$ 


\section{LIST OF TABLES}

Table 1

OAAT Fiscal Year 1996 Budget Appropriations

Table 2 Estimated U.S. Consumption of Alternative Fuels in Light-Duty Vehicles 10

Table 3

Vehicle Systems: Fiscal Year 1996 Program Participants 12

Table 4 Hybrid Vehicle Descriptions 23

Table 5 Chrysler Hybrid Propulsion System Performance Targets 25

Table 6 Chrysler Gen 1 Prototype Vehicle Specifications 26

Table 7 Energy Storage Requirements for Hybrid Vehicles 28

Table 8 Advanced Heat Engines: Fiscal Year 1996 Program Participants 34

Table 9 Electric Vehicle Battery Research and Development: Fiscal Year 1996

Program Participants 44

Table 10

Advanced Battery Technology for Electric Vehicles: Key Targets

Mid-Term (1998) and Long-Term (2000-2001) 45

Table 11

Fuel Cell Systems Research and Development: Fiscal Year 1996

Program Participants 51

Table 12

Advanced Automotive Materials: Fiscal Year 1996 Program Participants 61

Table 13 Alternative Fuels: Fiscal Year 1996 Program Participants 66 


\section{PREFACE}

This annual report serves to inform the United States Congress on the progress for fiscal year 1996 of programs under the Department of Energy's Office of Advanced Automotive Technologies (OAAT). This document complies with the legislative requirement to report on the implementation of Title III of the Automotive Propulsion Research and Development Act of 1978 (Public Law 95-238, 15 U.S.C. 2701 et seq.). It specifically fulfills the reporting requirements of subsections 304(f) and 310(a). Also reported are related activities performed under subsequent relevant legislation without specific reporting requirements. Furthermore, this report serves as a vital means of communication from the Department to all public and private sector participants.

Specific requirements of subsections 304(f) and 310(a) of Title III of Public Law 95-238 that are addressed in this report are:

\section{Subsection Title III Requirement}

304(f)(4) Discussion of how each research and development contract, grant, or project funded under the authority of this Act satisfies the requirements of this subsection

310(a)(1) Current comprehensive program definition for implementing Title III

$310(a)(2) \quad$ Evaluation of the state of automotive propulsion system research and development in the United States

310(a)(3) Number and amount of contracts and grants awarded under Title III

310(a)(4) Analysis of the progress made in developing advanced automotive propulsion system technology

310(a)(5) Suggestions for improvements in automotive propulsion system research and development, including recommendations for legislation

\section{Section of Report}

Appendix A

Section 2

Section 1,2

Appendix A

Section 2

Section 5 


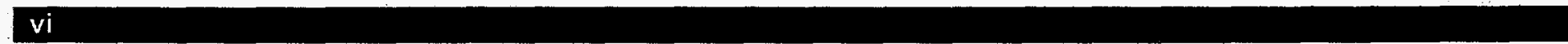




\subsection{INTRODUCTION}

\subsection{OVERVIEW}

This annual report presents the work that has been accomplished during fiscal year 1996 under the auspices of the Office of Advanced Automotive Technologies (OAAT) of the U.S. Department of Energy (DOE).

Significant strides have been made in the past two decades in improving automotive fuel economy and reducing automobile emissions. However, these gains have leveled off in recent years, and there remains considerable potential for making further improvement. The U.S. average passenger car fuel economy increased by nearly $70 \%$ from the mid-1970s to the mid-1980s. This was achieved largely through vehicle and engine design changes in response to government policies and consumer demand. However, the increase in fuel economy in the decade from the mid-1980s to the mid-1990s was less than $5 \%$.

Overall, the petroleum imports required to meet the needs of the transportation sector are continuing to rise, and stronger measures must be implemented in order to turn the situation around. The programs sponsored by the OAAT are aimed at doubling, and eventually tripling, the fuel economy of mid-size vehicles, as well as replacing petroleum-derived fuels with electricity and alternative fuels derived from domestic resources.

Allowing time for development, commercialization, and market penetration, it is estimated that the direct contribution of the technology advancements supported by OAAT will result in a reduction in oil consumption of one quarter of a million barrels per day by 2010 and three quarters of a million barrels per day by 2020 . If this is combined with reductions attributable to advancements achievable from other Office of Transportation Technologies (OTT) programs, the total reductions will be more than 1 million barrels per day in 2010, and nearly 2 million barrels per day in 2020 .

The technologies being developed under sponsorship and support of the OAAT are aimed at realizing the potential fuel economy improvements and emissions reductions that are achievable. Implementation of these advancements by the U.S. automobile industry will strengthen the Nation's economy, improve living standards, and reduce our vulnerability to energy price and supply volatility.

\section{ORGANIZATION}

Figure 1 is a fiscal year 1996 organization chart of the OAAT, one of four offices in the OTT. The OTT, in turn, is one of four end-use sectors reporting to the DOE Assistant Secretary for Energy Efficiency and Renewable Energy. The OAAT was established in March of 1996 to consolidate all of the Department's light vehicle technology research and development efforts into an integrated Advanced Automotive Technologies program.

In fiscal year 1996, there were six program areas and organizational teams within the OAAT as shown in Figure 1. The Vehicle Systems program area covered system requirements definition, modeling, and hybrid electric vehicle propulsion technology programs. The Advanced Heat Engines program area included gas turbine and piston engine technology research and development for light-duty vehicles, as well as associated combustion research. The Electric Vehicle Batteries program area focused on highenergy battery technology development and support of electric vehicle readiness activities. The Fuel Cell Systems program area covered programs in fuel cell, fuel processor, and fuel storage technology development. The Automotive Materials program area included programs to develop lightweight materials and propulsion system materials. The Alternative Fuels program area addressed technology research and development to facilitate the utilization of alternative fuels in automobile engines. 
FIGURE 1

Office of Advanced Automotive Technologies Organization

(for Fiscal Year 1996)

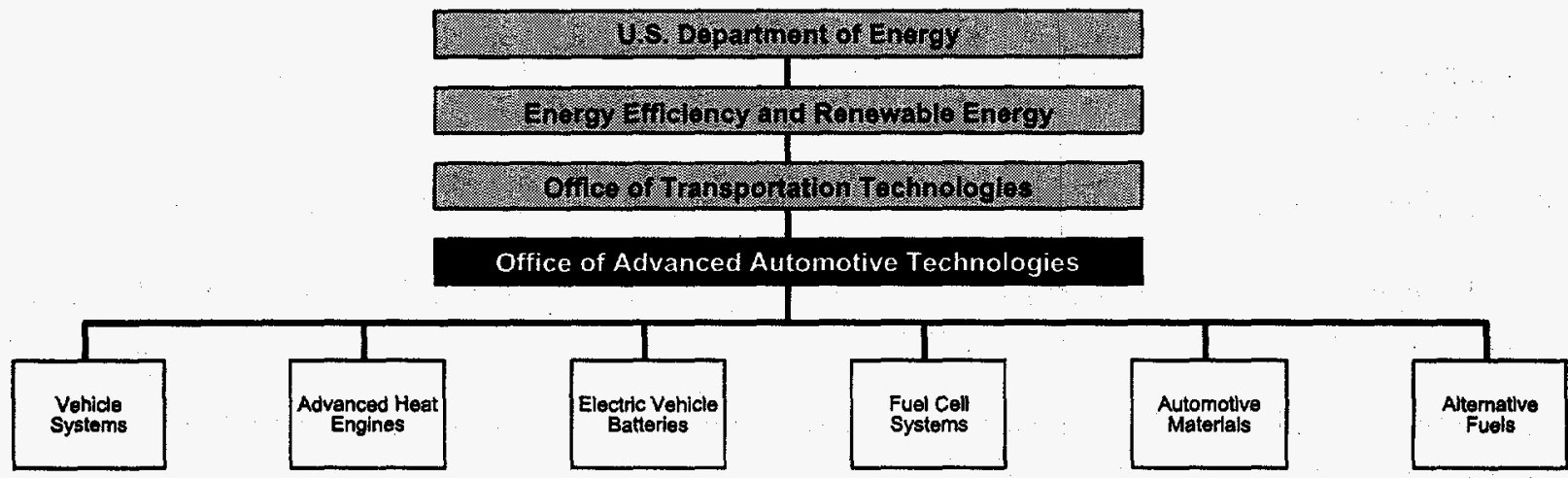

The budget appropriations for OAAT for fiscal year 1996 were distributed among the six program areas as shown in Table 1.

TABLE 1

OAAT Fiscal Year 1996 Budget Appropriations

\begin{tabular}{||l|c|}
\hline \multicolumn{1}{|c|}{ Program Area .1 .8} \\
\hline Vehicle Systems & Budget $(\$ 000)$ \% .1 .9 \\
\hline Advanced Heat Engines & $\$ 52,690^{*}$ \\
\hline Electric Vehicle Batteries & $\$ 5,350$ \\
\hline Fuel Cell Systems & $\$ 18,930$ \\
\hline Automotive Materials & $\$ 21,497$ \\
\hline Alternative Fuels & $\$ 18,232$ \\
\hline TOTAL & $\$ 2,205$ \\
\hline
\end{tabular}

* Includes funding for high-power energy storage devices, and power electronics and electric machines. Also includes funding for Gas Turbine Hybrid Power Unit (GT-HPU) research and development, which is conducted as part of Advanced Heat Engines activities.

\section{GOAL AND OBJECTIVES}

The goal and objectives of the OAAT programs arise from the OTT vision: Within the first decade of the twenty-first century, the United States will turn the corner in the growth of petroleum use for highway transportation. This vision follows from the primary DOE goals that apply to the OTT, which include:

- Enhance energy productivity to strengthen the U.S. economy and improve living standards;

- Ensure reliable energy services with reduced vulnerability to energy price and supply volatility; and

- Reduce adverse environmental impacts associated with energy production, delivery, and use.

The goal of the OAAT program is to research, develop, and validate technologies that will enable light vehicles to have:

- Several times the fuel economy of current, comparable conventional vehicles; 
- Fuel flexibility;

- Emissions that comply with statutory limits projected to be in place when the vehicles become available for the marketplace; and

- Other attributes, such as price, comfort, and safety, that would enable them to be competitive with conventional vehicles.

The objectives of the OAAT are to develop and validate the technology to achieve the following:

- By 1998, automotive propulsion subsystem technologies that will enable the achievement of 50 miles per gallon (mpg) in a test-bed six-passenger sedan;

- By 1999 , technologies that will enable the use of compressed natural gas as an alternative fuel in conventional automobiles, with full range and performance capability;

- By 2003, battery technologies that will render full-range electric automobiles commercially viable;

- By 2004, automotive technologies that will enable the achievement of $80 \mathrm{mpg}$ in a six-passenger sedan that could be successfully marketed by 2008 ;

- By 2008, technologies that will enable the use of ethanol as an alternative fuel to achieve $80 \mathrm{mpg}$ (gasoline equivalent) in demonstration automobiles; and

- By 2011, automotive technologies that use non-petroleum-based fuels and achieve zero emissions while obtaining $100 \mathrm{mpg}$ in lightweight vehicles that could be marketed by 2015 .

Much of the research and development work of the OAAT is directed toward the government/industry Partnership for a New Generation of Vehicles (PNGV) due to the similarity of the common OAAT objective and the PNGV goal of achieving up to $80 \mathrm{mpg}$ fuel economy in passenger cars while providing the same level of comfort, convenience, and affordability as today's vehicles. The PNGV is a cooperative effort between seven Federal Government agencies and the U.S. Council for Automotive Research (USCAR). The USCAR is a cooperative partnership between Chrysler, Ford, and General Motors. The breadth of the PNGV program extends beyond fuel economy improvements to include objectives, such as improvements in manufacturing technology, which do not fall under the purview of the OAAT. Several of the OAAT program areas also extend beyond the PNGV program. These include funding of research in electric vehicles and alternative fuels. Figure 2 schematically shows the interrelationships among the various technologies that are required to achieve the goal and objectives of the OAAT.

The strategy for achieving these objectives is focused on the research, development, and validation of energy-efficient technologies as final products.

\section{NATIONAL NEEDS}

The importance of the stated goal stems from the major challenges facing the U.S. in meeting the everincreasing demand for transportation goods and services while striving to minimize adverse energy, environmental, and economic impacts. Over $97 \%$ of the fuel consumed by the U.S. transportation sector involves petroleum-based fuels, and this use accounts for two-thirds of the Nation's total oil consumption. Vehicle fuel efficiencies have shown considerable improvement since the $1970 \mathrm{~s}$, but increases in population and per capita miles driven have more than offset these gains, contributing to an overall increase in consumption of petroleum for transportation. 
FIGURE 2

Technologies Under Research and Development

to Achieve OAAT Goal and Objectives

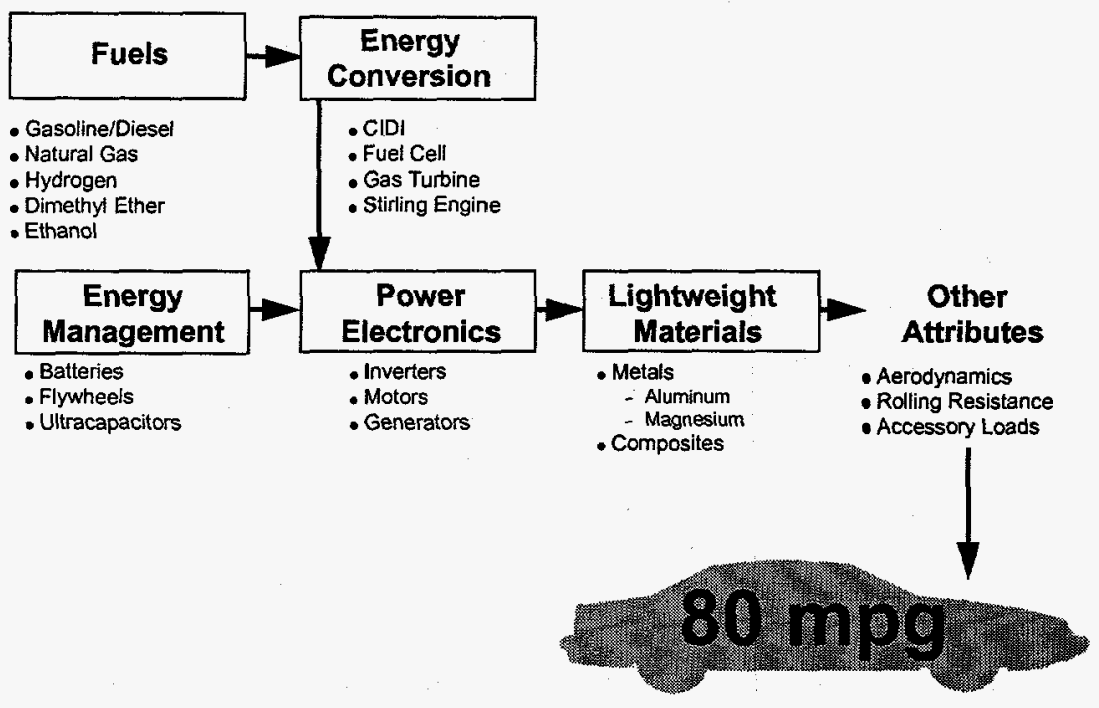

Figure 3 shows the new car fleet average fuel economy (mpg) in the U.S. for model years 1975 to 1996. It shows a dramatic reduction in vehicle inertia weight and a corresponding improvement in fuel economy between 1976 and 1980. Improvements in fuel economy have reached a plateau since 1988 and vehicle inertia weight has been slowly increasing in the same time period, indicating that vehicle efficiency has been increasing at only a modest pace. One of the primary reasons for the trend toward increasing average vehicle weight is the popularity and high sales volumes of sport utility vehicles, vans, and light trucks. These types of vehicles are required to meet less stringent Corporate Average Fuel Economy (CAFE) standards than passenger automobiles. The increase in vehicle fuel economy shown in the figure is offset to a great extent by the increase in total vehicle miles traveled each year, as shown in Figure 4. The net effect is a substantial growth in overall fuel consumption and corresponding petroleum imports, as shown in Figure 5. This trend is likely to continue unless further progress is made in achieving substantial improvements in vehicle fuel economy and increasing the use of domestically produced alternative fuels.

In 1995, the net imports of petroleum represented $44 \%$ of domestic petroleum consumption, close to the 1977 record level of $46 \%$. The Energy Information Administration (EIA) predicts that the percentage will reach $61 \%$ in 2015 . The EIA also forecasts that shortly before the turn of the century, more than $60 \%$ of the oil traded in the international market will come from the Persian Gulf, a region characterized by continued political instability. The growing level of imported petroleum also represents a massive transfer of wealth from the U.S. to oil-exporting countries. In 1995, the U.S. paid $\$ 49$ billion for imported petroleum. The growing reliance on imported petroleum is becoming a national concern.

In December 1994, the Department of Commerce (DOC) concluded that our growing reliance on lowpriced crude oil from unstable foreign sources threatens national security by leaving the U.S. increasingly vulnerable to the potentially serious adverse economic impacts of disruptions in oil supply. The DOC also noted that "political and economic problems in the Persian Gulf region make supply disruptions a possibility in the near-term." Rather than employing import adjustments, such as tariffs and quotas, to address the situation, the DOC recommended reducing the demand for petroleum by implementing a number of measures, including the design of more energy-efficient cars and the introduction of alternative transportation fuels and vehicles into the marketplace. 
FIGURE 3

Passenger Car Fuel Economy and Inertia Weight

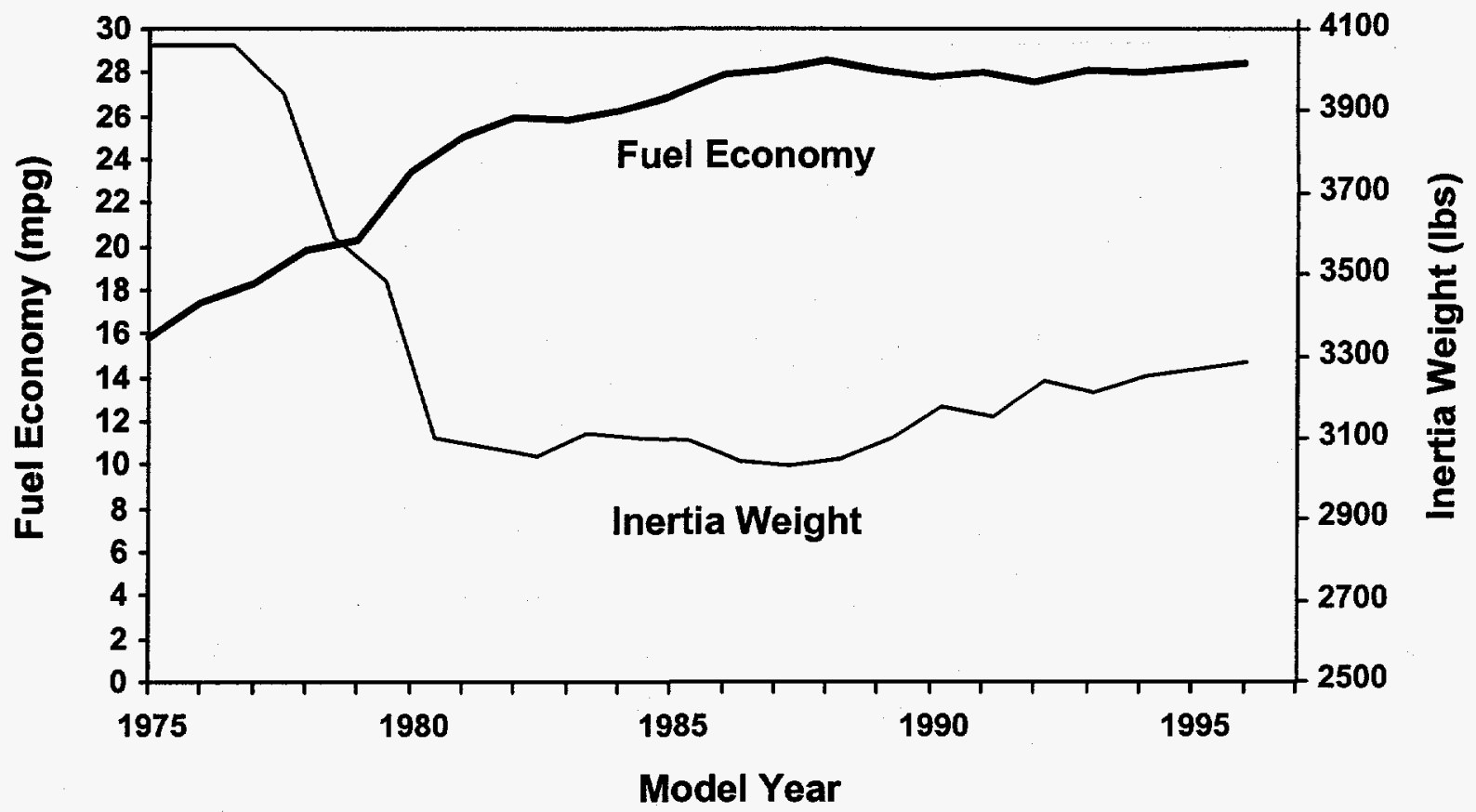

Source: U.S. Environmental Protection Agency, Light-Duty Automotive Technology and Fuel Economy Trends Through 1996, Technical Report, EPA/AA/TDSG/96-01, August 1996.

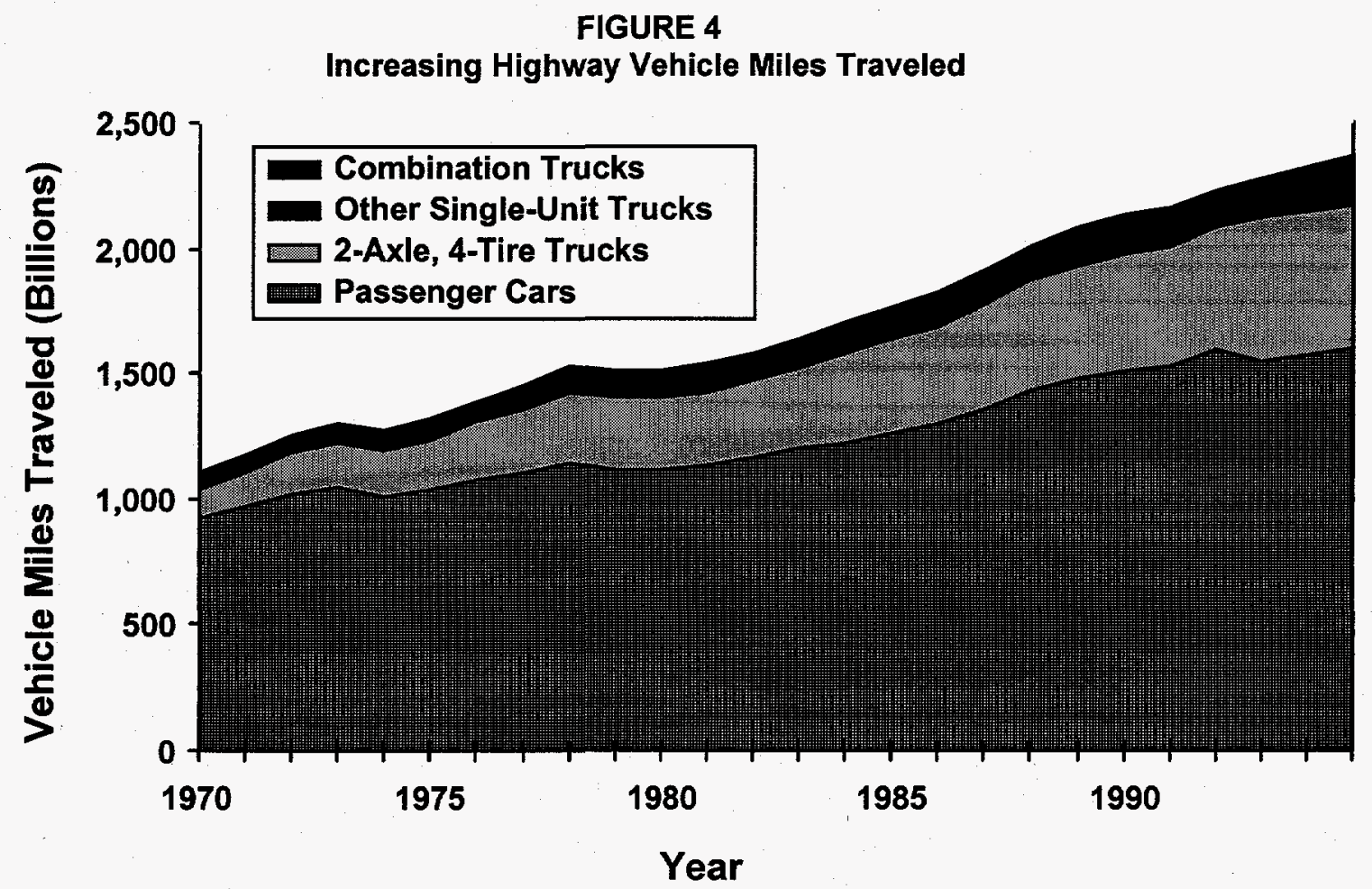

Source: U.S. Department of Energy, Transportation Energy Data Book: Edition 16, ORNL-6898, July 1996. 
FIGURE 5

Transportation Contribution to Our Growing Dependence on Imported Oil

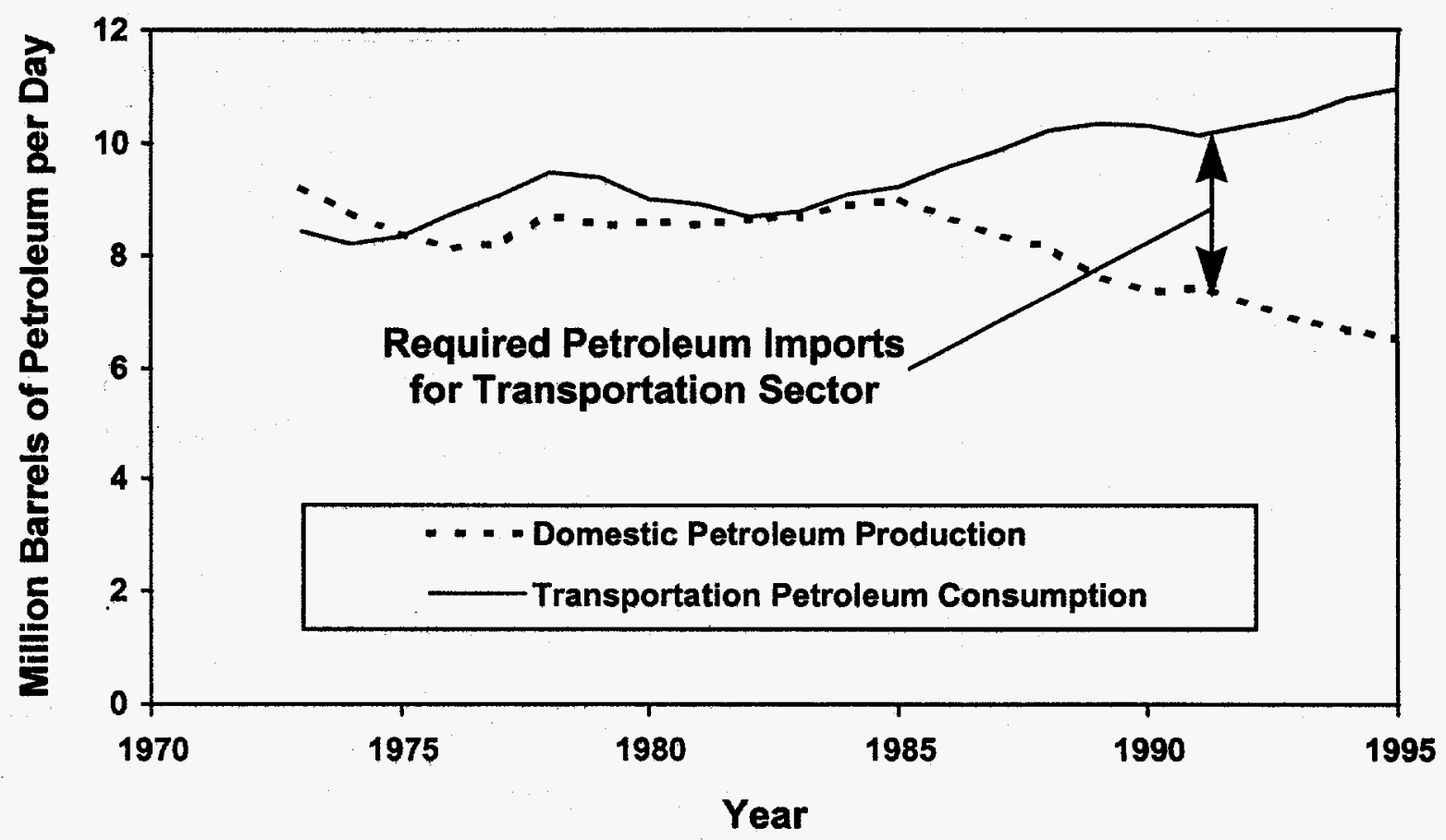

Source: U.S. Department of Energy, Transportation Energy Data Book: Edition 16, ORNL-6898, July 1996.

There is also continuing concern about poor air quality and levels of greenhouse gas emissions. The transportation sector is a major contributor to air pollution in the U.S. In 1994, the transportation sector was responsible for $78 \%$ of the U.S. total carbon monoxide emissions, $45 \%$ of the total U.S. oxides of nitrogen (NOx) emissions, $37 \%$ of the total emissions of volatile organic compounds, and $32 \%$ of the emissions of lead. There has been steady improvement, but the gains are offset to some degree by the increase in vehicle miles traveled each year. Figure 6 shows, on a normalized scale, the emission level trends of five major pollutants from highway vehicles per mile traveled.

Another issue is increasing global market competition in the transportation sector. Other automobile manufacturing countries (most notably Japan and the European nations) have committed substantial public funds to support advanced automotive research in partnership with their domestic manufacturers. All indications suggest a long-term commitment by these governments to the development and production of advanced vehicles, both for the domestic and the export markets. The emerging economies of Asia, Latin America, and Eastern Europe, where much of the future growth in the automotive market is expected, are becoming a competitive marketplace for the global automotive industry. These markets are expected to be particularly receptive to cost-competitive advanced vehicles with high fuel economy and low emissions.

\subsection{STATUS OF CONVENTIONAL POWERTRAIN TECHNOLOGY}

Passenger cars, sport utility vehicles, light trucks, and vans, the vehicles of choice for personal transportation in the U.S., are substantially more efficient than when the Automotive Propulsion Research and Development Act of 1978 (Public Law 95-238) was enacted. The efficiency improvements are due to a combination of engine and powertrain efficiency gains along with weight reduction, aerodynamic improvements, and a reduction in tire rolling resistance. Electronic control of automatic transmissions, fuel injectors, valve timing, and valve lift control have also contributed to improved efficiency. The use of lighter and stronger materials and improved design engineering have also been major contributors. The use of alternative fuels, particularly natural gas, for reducing emissions is becoming more widespread for light-duty vehicles. The increased availability of reformulated gasoline 
Relative Highway Vehicle Emissions per Mile Traveled (Base 1970)

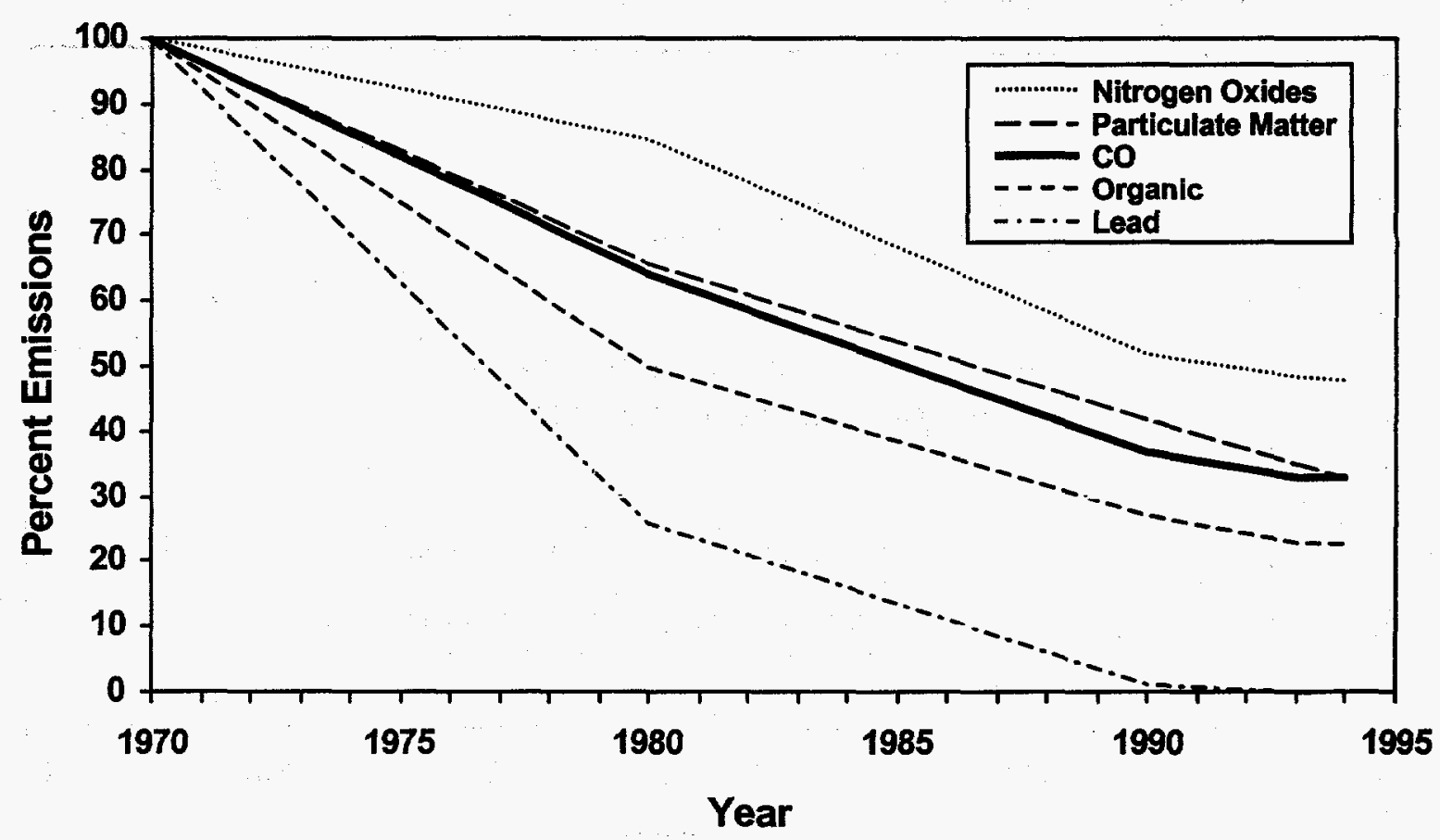

Source: U.S. Department of Energy, Transportation of Energy Data Book: Edition 16, ORNL-6898, July 1996.

in certain areas of the country is also contributing to reduced emissions from gasoline-powered vehicles. Some of the emissions reduction also can be attributed to the Federal Motor Vehicle Control Program, which has resulted in the widespread use of catalytic converters on automobiles to reduce not only carbon monoxide emissions but also NOx and volatile organic compound emissions.

\section{FOUR-STROKE SPARK IGNITION PISTON ENGINES}

For model year 1997, light-duty vehicle manufacturers continued a trend toward increased use of multi-port fuel injection systems, which allows for precise control of the air-fuel ratio for better performance, improved throttle response, lower emissions, and better fuel economy. The continuing trend toward lighter rotating and reciprocating engine and transmission parts is made possible by a combination of better designs and materials. Lighter weight rotating and reciprocating components reduce inertia and the resulting forces and stresses, thereby allowing related engine components, such as camshafts, connecting rods, crankshafts, and bearings, to be lightened in a synergistic way. The reduced inertia and mechanical stress in these components allow engines to be operated at higher speeds, which improves the power capability of engines without resorting to increased displacement. Alternatively, a smaller size engine can produce the same power, allowing for further space and weight savings in the vehicle structure and a reduction in engine friction.

Improved air management is being applied to some engines with the use of tuned and/or variable-length intake manifolds. An increasing number of automobiles are manufactured with intake manifolds that are formed from composite plastic materials. In addition to having a smooth internal surface finish for minimal airflow restriction, these materials are lighter than aluminum and can also be recycled.

Many new engines incorporate technologies designed to increase efficiency by reducing friction, including roller cam followers, lightweight pistons, and precision machined crank journals. Piston ring height and tension have been modified to reduce surface area and ring friction while maintaining a durable ring seal. 
Lightweight materials, such as aluminum and magnesium, are being used in automobile powertrains in greater amounts. There is also increased use of powder metallurgy technology due to its ability to form strong, complex shapes with less expense and time-consuming machining. Its use has nearly doubled since 1978.

Advanced spark plugs are being developed for longer life, with various electrode configurations and shapes, for higher-voltage ignition systems, in smaller sizes, and as part of combustion-sensing systems. Platinum tipped spark plugs are being used in many car models, resulting in extension of scheduled maintenance intervals to 100,000 miles. Improved and simplified powertrain modules in some engines have added four times the computer power with one-half the number of components. This has resulted in increased diagnostic capability and improved powertrain control at a reduced cost.

\section{TWO-STROKE AND ROTARY SPARK IGNITION ENGINES}

In the past, the U.S. automotive industry had pursued development of two-stroke engines for automobiles because of their potential advantages of simplicity, fewer parts, lower manufacturing costs, reduced weight, and improved fuel economy compared to equivalent four-stroke engines. However, it appears that the U.S. automobile industry has suspended further development of the two-stroke engine because increasingly stringent emission regulations tend to reduce the two-stroke engine's potential for commercial viability in automotive applications.

The automotive rotary engine has been used in limited sports car applications, but sales of rotary powered vehicles have decreased to the point in recent years that they are no longer marketed in the U.S. The rotary engine offers excellent performance and competitive reliability compared to conventional reciprocating engines and has the added benefits of mechanical simplicity, low noise, and low vibration. However, the fuel economy and emissions of the rotary engine have not equaled those of conventional engines for general automotive applications.

\section{DIESEL ENGINES}

The number of diesel engines used in light-duty vehicles in the U.S. has been small relative to the number used in European countries. The sales of new diesel automobiles in the U.S. increased from $1.02 \%$ of total automobiles sales in 1978 to a peak of $6.1 \%$ in 1981 . The sales of new diesel automobiles decreased sharply to $0.02 \%$ in 1988 and was $0.04 \%$ in 1995 . The application of diesel engines in light trucks, 10,000 lbs gross vehicle weight and less, increased from $1.0 \%$ of total light truck sales in 1978 to a peak of $5.0 \%$ in 1982 . Since that time, the percentage of new diesel light truck sales decreased to a low of $2.0 \%$ in 1988 but have increased to $2.7 \%$ in 1994 .

In past years, the diesel engines used in light-duty vehicles predominantly employed indirect injection. The trend now is toward the use of direct injection diesel engines, which offer a substantial advantage in thermal efficiency over indirect injection diesels. However, their emission of NOx tends to be more difficult to control.

In order to reduce the emission of NOx from the lean oxidizing environment of direct injection diesel engine exhaust, considerable research and development is being conducted to develop diesel/lean NOx catalyst technologies. Using such catalysts, a reduction in NOx by $25 \%$ has been achieved in passenger car tests and approximately $40 \%$ reduction for truck engine tests. However, commercialization of such catalysts has not been achieved to date because the durability goals have not yet been reached.

\section{TRANSMISSIONS AND BRAKE SYSTEMS}

New automatic transmissions for U.S. light-duty vehicles utilize electronic controls that monitor key vehicle parameters, including throttle position, vehicle speed, gear range, and engine load to create seamless operation between the engine and the transmission. Gear shifts are controlled by powertrain 
management computers, which activate solenoid-operated shift valves on a schedule designed for the best balance of performance and economy. Some automatic transmissions feature altitude compensation, which allows the transmission to adjust for the changes in engine output. Evolutionary refinements in electronic transmission control are occurring with each new model year. Automatic transmission fluids are now available that last the life of the car under normal service. In addition to reducing ownership costs, the elimination of periodic transmission fluid changes significantly reduces the amount of waste oil that must be recycled. The domestic industry's first 5 -speed automatic transmission has been introduced into a sport utility vehicle.

Sophisticated interactive traction control systems are now available on some vehicles. These systems work together with antilock brake systems and combine brake action control with engine torque reduction when wheel slip is detected. Vehicles with traction control can potentially satisfy the needs of some customers who would otherwise purchase vehicles with less fuel-efficient four-wheel-drive powertrains.

Automotive components suppliers typically manufacture parts such as brake rotors and brake calipers from ferrous materials, but these same suppliers may soon build these components from new advanced composites that use ceramic particles dispersed in an aluminum alloy matrix for weight savings and improved performance.

\section{ALTERNATIVE FUELS}

Domestically produced alternative fuels such as natural gas, methanol, ethanol, propane, and biodiesel (a mixture of conventional diesel fuel with a renewable diesel-like fuel formulated from agricultural plant oils and animal fats), offer the potential of reducing U.S. dependence on imported petroleum and transportation's contribution to air pollution.

Alternative fueled engines have been developed, and some have shown emissions advantages over conventional engines. A number of U.S. manufacturers have introduced alternative fueled engines and/or vehicles to the marketplace. Many facilities around the country are capable of converting conventional vehicles to use alternative fuels.

As shown in Table 2, the use of alternative fuels in light-duty vehicles increased by approximately $38 \%$ during the period from 1992 to 1996 . Only the consumption of M100 (100\% methanol) and E95 ( $95 \%$ ethanol, $5 \%$ gasoline) have shown a decrease during that time period. 
TABLE 2

Estimated U.S. Consumption of Alternative Fuels in Light-Duty Vehicles (thousand gasoline-equivalent gallons)

\begin{tabular}{|c|c|c|c|}
\hline Atremative fuel & 1992 & 1994 & 1096 \\
\hline Liquefied petroleum gas & 141,042 & 167,300 & 177,200 \\
\hline Compressed natural gas & 10,477 & 15,490 & 28,949 \\
\hline Liquefied natural gas & $>0.5$ & $>0.5$ & $>0.5$ \\
\hline M85 ( $85 \%$ methanol, $15 \%$ gasoline) & 607 & 2,290 & 3,490 \\
\hline M100 (100\% methanol) & 13 & 0 & 0 \\
\hline E85 (85\% ethanol, $15 \%$ gasoline) & 20 & 80 & 1,030 \\
\hline E95 (95\% ethanol, $5 \%$ gasoline) & 3 & $>0.5$ & $>0.5$ \\
\hline Electricity & 226 & 280 & 311 \\
\hline TOTAL* & 152,338 & 185,440 & 210,979 \\
\hline
\end{tabular}

* This table does not include the use of ethanol and methanol as oxygenate additives that are blended into today's petroleum based gasoline. Consumption of oxygenate additives has increased from 2,106,000 thousand gasoline-equivalent gallons in 1992 to 4,407,000 thousand gasoline-equivalent gallons in 1995 .

Source: Alternatives to Traditional Transportation Fuels 1994, Volume 1, Energy Information Administration, DOE/EIA-0585 (94)/1, February 1996. 


\subsection{ADVANCED AUTOMOTIVE TECHNOLOGIES RESEARCH AND DEVELOPMENT}

\subsection{VEHICLE SYSTEMS}

\section{INTRODUCTION}

The objective of the Vehicle Systems Program is to develop, validate, and integrate advanced vehicle systems in support of the Office of Advanced Automotive Technologies' (OAAT) goals of achieving revolutionary improvements in fuel economy, while meeting statutory emission and safety standards, and enhancing the capability to use domestically produced alternative fuels. During fiscal year 1996, the Vehicle Systems Program focused on hybrid electric vehicle technology, one of the leading candidates for achieving the fuel efficiency objectives of OAAT. The near-term objective is to develop and validate production-feasible hybrid propulsion system technologies that will enable the achievement of $50 \mathrm{mpg}$ in a test-bed six-passenger sedan by 1998 . This is an intermediate milestone toward the longer term goal of demonstrating and validating production-feasible vehicle technologies that will enable the achievement of $80 \mathrm{mpg}$ in a test-bed six-passenger sedan by 2004 , consistent with the goals of the Partnership for a New Generation of Vehicles (PNGV).

In support of these ambitious goals, the Vehicle Systems effort is composed of three major elements directed toward: (1) Technology Requirements and Validation, (2) Technology Development, and (3) Advanced Vehicle Competitions.

The objective of the Technology Requirements and Validation effort is to establish, within the context of a total vehicle perspective, technology attribute requirements and targets for vehicle systems and components. These technology attribute requirements and targets serve as the focus for all OAAT technology development activities. Powerful systems analysis and component-level modeling tools are being developed and utilized to simulate vehicle/subsystem performance, to define the technology requirements, and to verify that target performance characteristics for the total automobile are achievable. These modeling capabilities supplement tests and evaluation of hardware in test-bed vehicles.

The objective of the Technology Development effort is to develop representative integrated test-bed vehicles that can be used as platforms for system/component-level optimization, technology validation, and model verifications. In addition, key enabling technologies are being supported, including highpower energy storage devices such as batteries, ultracapacitors, or flywheels, and cost-effective, highefficiency power electronics and compact electric drive systems.

The objective of the Advanced Vehicle Competitions is to bring together the expertise and talents of government, industries, and universities to look beyond conventional automotive approaches in order to develop and evaluate test vehicles to advance automotive technology to meet the goals of improved fuel economy and reduced emissions. Several nationwide competitions are held each year, with vehicles built by university teams with government support and extensive industry sponsorship.

The above three elements of the Vehicle Systems effort are inherently synergistic and are being implemented in an integrated manner. Multiple competitive teams of domestic automakers and their suppliers are at work with support from the other Federal agencies, national laboratories, suppliers, and universities (see Table 3). 
TABLE 3

Vehicle Systems

Fiscal Year 1996 Program Participants

\begin{tabular}{|c|c|c|}
\hline Participantorganization & Mechanism & $\begin{array}{l}\text { Paticipant: } \\
\text { cost share }(\%)\end{array}$ \\
\hline \multicolumn{3}{|l|}{ Hybrid Propulsion Systems } \\
\hline Chrysler Corporation & Contract & 50 \\
\hline Ford Motor Company & Contract & 50 \\
\hline General Motors Corporation & Contract & 50 \\
\hline National Renewable Energy Laboratory & Field Work Proposal & 0 \\
\hline \multicolumn{3}{|l|}{ High-Power Energy Storage } \\
\hline SAFT America & Contract & 50 \\
\hline SRI International & Contract & 50 \\
\hline Varta & Contract & 50 \\
\hline Yardney & Contract & 50 \\
\hline Maxwell & Contract & 20 \\
\hline Federal Fabrics & Contract & 0 \\
\hline General Electric & Contract & 50 \\
\hline University of Wisconsin & Grant & 0 \\
\hline $\begin{array}{l}\text { Idaho National Engineering Laboratory } \\
\text { Lawrence Berkeley National Laboratory } \\
\text { Argonne National Laboratory }\end{array}$ & Field Work Proposal & 0 \\
\hline \multicolumn{3}{|l|}{ Power Electronics } \\
\hline U.S. Navy/Harris Semiconductor & Contract & 85 \\
\hline $\begin{array}{l}\text { Sandia National Laboratories } \\
\text { Oak Ridge National Laboratory }\end{array}$ & Field Work Proposal & 0 \\
\hline \multicolumn{3}{|l|}{ Advanced Vehicle Competitions* } \\
\hline Argonne National Laboratory & Field Work Proposal & 0 \\
\hline
\end{tabular}

* The Advanced Vehicle Competitions Program is only partially funded by the government. Industry and universities provide substantial support for this program as sponsors and providers of equipment and facilities.

\section{HYBRID PROPULSION SYSTEMS}

\section{TECHNOLOGY BACKGROUND}

The hybrid electric vehicle (HEV) combines two or more energy conversion technologies (e.g., heat engines, fuel cells, generators, or motors) with one or more energy storage technologies (e.g., batteries, ultracapacitors, or flywheels). The hybrid propulsion system takes advantage of the strengths of each constituent technology, resulting in a vehicle with two to three times the fuel efficiency of current vehicles without compromising other attributes such as performance, emissions, control, safety, or cost. 
Hybrid vehicles are expected to meet the Environmental Protection Agency's stringent emission standards expected to be in place by 2004 , and provide more than a $60 \%$ reduction in tailpipe carbon dioxide emissions compared to current conventional vehicles of comparable size.

Hybrid propulsion systems can be designed to incorporate a range of competing and complementary technologies. They can be configured in series or parallel configurations, or a combination of the two. In a series $\mathrm{HEV}$, the heat engine drives an electric generator to produce electricity. The electricity is then stored in the batteries or drives the electric motor to power the vehicle. A parallel HEV is configured so that either the heat engine or the electric propulsion system -- or both -- can be used to power the vehicle. Figure 7 shows schematic diagrams of typical series and parallel HEV configurations.

Under the Vehicle Systems effort, extensive conceptual design and systems analysis activities have been undertaken by contractor teams to develop preferred system configuration and technology options to meet the intermediate program goal of up to $50 \mathrm{mpg}$ in a test-bed six-passenger sedan by 1998 .

FIGURE 7

Schematic Diagrams of Typical Series and Parallel HEV Configurations

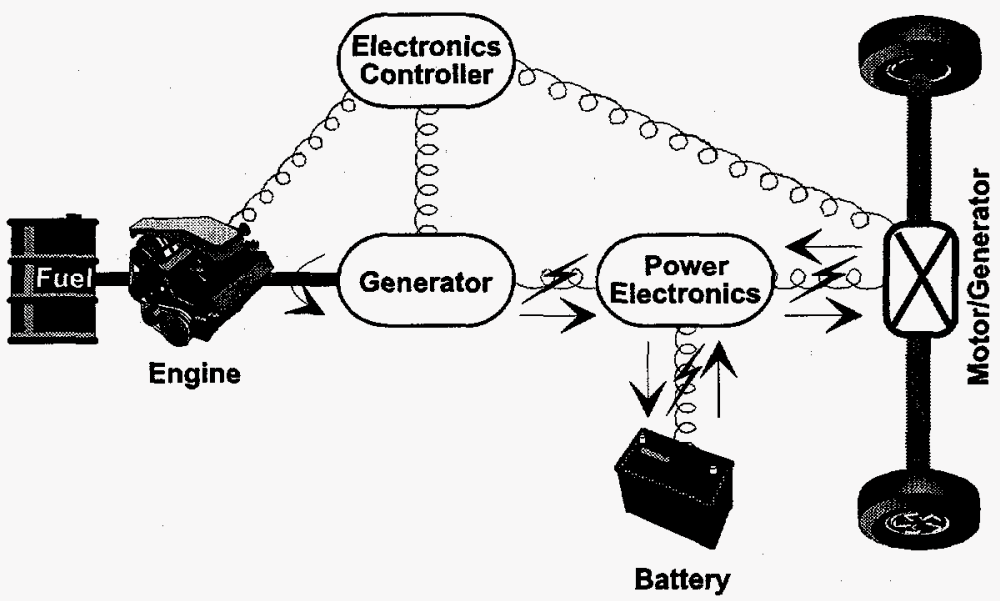

Series Hybrid Configuration

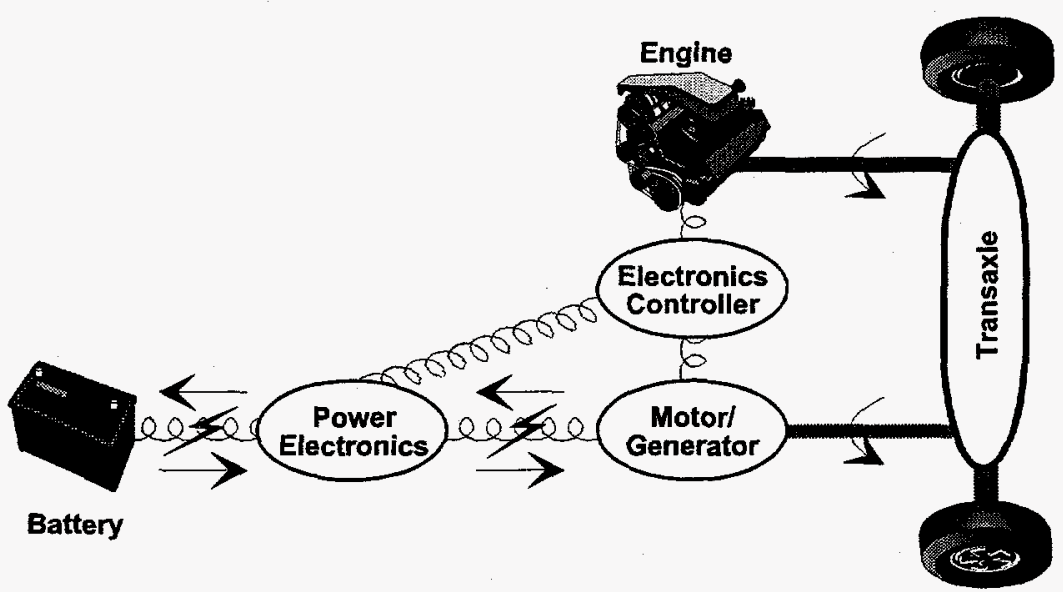

Parallel Hybrid Configuration 
Although the hybrid vehicle technology under development is promising, there are many technical barriers that must be overcome. Key barriers and challenges include:

- Devices with high power-to-energy ratios to augment power for vehicle acceleration and hill climbing are not yet available. The devices must be thermally managed and have a high specific power, long life, and competitive cost.

- Size, weight, and cost of power electronic devices must be reduced.

- Current engine-based hybrid power units need to convert fuel to useful power more efficiently while complying with projected emissions standards.

- More advanced mathematical models of propulsion system components (both steady state and dynamic) are needed, with supporting data, for a variety of vehicle subsystems. Component models are being improved and integrated into system-level performance models for validation with test data derived from prototype vehicles.

\section{PROGRAM ACTIVITIES}

In fiscal year 1996, the hybrid systems development effort entered its fourth full year. Cost-shared contracts are now in place with Chrysler, Ford, and General Motors. These contracts are managed through the National Renewable Energy Laboratory (NREL), and include more than 30 subcontracts with component and subsystem suppliers, small businesses, national laboratories, and universities. The Chrysler systems technology development contract was awarded in March 1996, with goals and terms similar to the earlier Ford and General Motors contracts, but with a more compressed time schedule.

\section{Systems Analysis Activities}

The vehicle simulation model developed at NREL, called ADVISOR, has continued to be enhanced through working with component developers, the auto industry, and participants in the PNGV, and is the central tool used for the systems analysis and technology integration. ADVISOR is designed for systemlevel analyses, tradeoffs, and optimizations.

NREL staff performed simulations to guide lower-tier subcontractors and facilitate communications among the prime subcontractors, lower-tier subcontractors, and program management. Results from the HEV ADVISOR simulation program are used by NREL project managers to help oversee the prime subcontracts.

The first step to improve ADVISOR is to validate the component models and the overall vehicle modeling algorithms with data collected through university subcontracts. Four separate subcontracts with universities are providing this data. Component suppliers are an increasingly important source of validated data, and relationships established with suppliers allow non-proprietary component models and data to be added to the ADVISOR component toolbox.

The Systems Analysis goals are to: further develop and use NREL's HEV performance modeling capabilities to guide U.S. investment in vehicle technology research and development; support the PNGV Systems Analysis Team; support the General Motors, Ford, and Chrysler subcontracts; and enable proper technical management of the subcontracts. The primary objectives of this task are:

- To assist decision makers on vehicle system and component development programs, provide project direction, and define technology attribute targets that can serve as the focus for technology research and development. 
- To create a tool that will facilitate the evaluation of component technologies in the context of a total vehicle.

- To support the PNGV systems analysis effort through specific tasks identified by the PNGV Systems Analysis Steering Committee.

- To assist the original equipment manufacturers (OEMs) in modeling efforts through assisting in trade-off studies for their internal down-selection decisions.

\section{Fiscal Year 1996 Accomplishments}

- National Lab support provided component data and simulation models of advanced HEV components to the PNGV Systems Analysis Toolkit model, such as flywheels, motors, batteries, and continuously variable transmissions (CVTs).

- NREL validated its HEV simulation software model, ADVISOR, against Ford, General Motors, and Chrysler's models in a benchmarking exercise to correlate the results, which all agreed within $5 \%$.

- NREL refined and distributed a publicly available version of ADVISOR, which is now used by more than 20 companies and organizations throughout the U.S.

- Advanced component data for HEVs was collected from three universities in order to facilitate further validation of the ADVISOR model and build up the database of models available for use in simulation.

- Detailed HEV modeling for Chrysler's hybrid prototype was initiated by using ADVISOR as an initial vehicle simulator, and then building a specialized model to meet the needs of Chrysler through a cooperative Chrysler and NREL effort.

\section{General Motors Subcontract Activities}

\section{Introduction}

The General Motors Hybrid Vehicle Propulsion System Program was initiated on September 30, 1993. During fiscal year 1996, Phase B of the program, the System Design Phase was completed and the program transitioned into Phase C, the System Development and Validation Phase. The overall goals of the General Motors program are to develop production feasible hybrid vehicle propulsion system technology that can be integrated into a family sedan (e.g., Chevrolet Lumina), which will facilitate a fuel economy improvement of up to two times the current fuel economy and will meet proposed Federal Tier 2 emissions standards without compromising existing consumer expectations for performance, driveability, comfort, and safety.

During Phase A (Systems Analysis Phase) of the program, General Motors performed a detailed engineering study on the relative merits of a variety of both series and parallel hybrid electric propulsion system architectures. In parallel with its technical analysis, information was gathered on consumer preferences for advanced technology vehicle attributes along with marketplace sensitivity to premium pricing for the additional value that hybrid vehicles could potentially offer.

As a result of the analytical efforts conducted during Phase $A$, and recognizing that the program has definitive limits on funding and time, it was decided at the beginning of Phase $B$ that future efforts would focus exclusively on a series hybrid propulsion system architecture. The series hybrid architecture of choice for all future development under the auspices of the program was further defined to be the "dual mode" type. This type of hybrid propulsion system provides the greatest level of operational flexibility to the consumer. It affords the opportunity to choose whether to operate on battery power alone, i.e., as 
zero-emission vehicle (ZEV) for short trips, or in full hybrid mode when undertaking a long journey. A dual mode series hybrid vehicle could even be operated on the Hybrid Power Unit (HPU) alone, although at reduced performance, if there was a failure in the energy storage system, thus providing the consumer "limp home" capability.

Another benefit of the series type of hybrid propulsion system architecture is the ability to employ continuous combustion engine technologies which have demonstrated sub-ULEV (ultra-low-emission vehicle) capabilities, such as Stirling and gas turbine, without sacrificing the vehicle's driveability due to the historically poor ability of these types of engines to rapidly respond to load change. These types of engines have combustion systems that are generally more flexible and easier to modify to operate on alternative fuels such as ethanol, methanol, and natural gas, in comparison to their spark ignited and compression ignited internal combustion engine (ICE) counterparts.

Commonly recognized drawbacks of series hybrid propulsion systems are increased cost, complexity, volume, and mass in comparison to parallel hybrid propulsion system configurations designed to meet the same vehicle performance requirements.

\section{Program Activities}

Fiscal year 1996 spanned two phases of the program. The first half of the fiscal year was marked by the culmination of Phase B, the System Design Phase of the program. Activities supporting Phase C, the System Development and Validation Phase, the third and final phase of the program, were launched as planned in April 1996.

Phase B Activities. During the first six months of fiscal year 1996, the Gen 1-1 system mule vehicle with a gas turbine HPU and spiral-wound lead-acid battery pack was assembled and controls, debugging, and testing activities began. Initial operation of the major vehicle subsystems including the HPU, Energy Storage System (ESS), Electric Drive Unit (EDU), Electric Power Steering (EPS), and climate control system were all achieved. A second Gen 1-1 gas turbine HPU underwent test stand development at the supplier's facility in preparation for replacing and upgrading the HPU in the Gen 1-1 system mule vehicle. The battery pack supplier built a second Gen 1-1 pack for long-term cycling experiments to support the characterization of pack performance and the development of pack management techniques. A control system integration bench consisting of all vehicle controllers and simulated subsystems was built and used to check out software and inter-controller interfaces, thereby allowing control system integration in advance of vehicle integration.

Vehicle packaging and component design efforts for the Gen 1-2 system mule vehicle with a Stirling cycle HPU were conducted in parallel with the Gen 1-1 vehicle activities. The Stirling cycle HPU supplier initiated test stand development of the Gen 1-2 engine. The Gen 0 Hybrid Technology Test-Bed vehicle that was completed during Phase A was maintained in a state of operational readiness and periodically used to test components and subsystems of the Gen 1-1 configuration level as they became available.

Phase C Activities. Shortly after the commencement of Phase C, following a review of the status of the two HPU suppliers, it was decided to stop the development work on the gas turbine HPU. Hence, all available resources were redirected to support the development of the Stirling HPU. It was further decided to abandon efforts to make the Gen 1-1 gas turbine mule vehicle fully operational. The Gen 1-1 mule vehicle was used to test the electric drive system and batteries in ZEV mode and supported the development of the thermal management system, electrically driven air conditioning, electric power steering, and regenerative braking system. After completion of these development activities, the Gen 1-1 components were removed and the vehicle is currently undergoing conversion to accept Gen 1-2 components in the future. 
The packaging team completed a packaging mock-up at General Motors Milford Proving Grounds that simulated the final configuration of the Gen 1-2 system mule vehicle. A major structural modification of the Gen 1-2 system mule vehicle was accomplished to accommodate the much improved Gen 1-2 battery pack configuration. The assembly of the Gen 1-2 system mule vehicle was completed, and the Stirling cycle HPU was operated for the first time in the vehicle on September 20, 1996.

Electric Drive Development Activities. The electric drive system consists of the motor/gearing assembly, otherwise referred to as the EDU, the Power Electronics Bay (PEB), and the electronic controls housed within the PEB. All of these components were designed specifically for application to both the Gen 1-1 and Gen 1-2 system mule vehicles; however, incremental improvements were made between the Gen 1-1 and Gen 1-2 versions.

The EDU is composed of an AC induction motor driving into a set of fixed ratio reduction gears and differential, all of which is integrated into a common housing that replaces the transaxle found in a conventional front wheel drive vehicle. An adapter plate on one end of the EDU housing allows the system to be used with either the gas turbine or the Stirling HPUs. See Figure 8.

To date, work on the EDU has been making excellent progress toward achieving its technical targets. The EDU has achieved $90 \%$ of the target levels for maximum torque and mass. Average drive efficiency throughout the entire driving cycle is within a percentage point of the target. The goal for continuous power output has been met. The major cost drivers have been identified as the housing, gears, rotor assembly, and stàtor assembly, and cost reduction measures are being implemented.

The PEB houses the Insulated Gate Bipolar

FIGURE 8 Electric Drive Unit

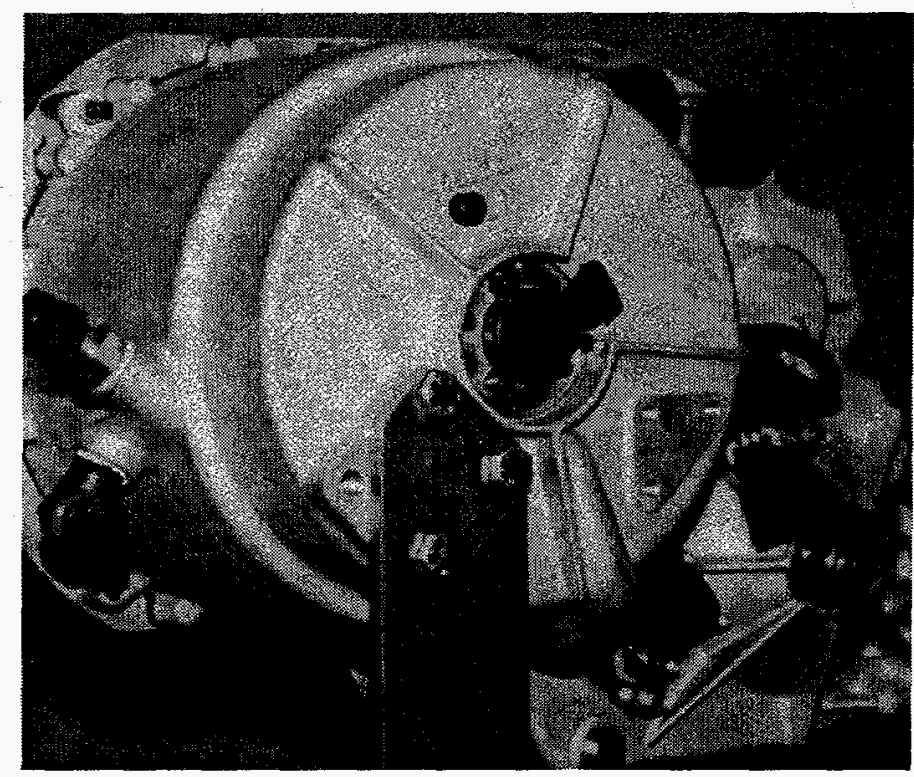

Transistor (IGBT) power switching devices that electronically communicate with the AC induction motor. Also contained within the PEB are the controllers for the air conditioning compressor, auxiliary heater, and electric power steering system. An auxiliary power supply to power the $12 \mathrm{~V}$ vehicle systems and an onboard battery charger are also packaged within the PEB. The technical targets for inverter efficiency, continuous power output and peak power output, have all been met or exceeded. However, the weight of the PEB is projected to be $50 \%$ above the target. Current estimates for piece price cost at production volumes are reasonably close to the objective. Considerable effort still needs to be exerted to improve the reliability of the PEB with respect to electromagnetic interference (EMI) from the high voltages and switching frequencies. The Gen 1-1 PEB is shown in Figure 9.

HPU Development Activities. At the beginning of fiscal year 1996, two candidate engine technologies were still under consideration for use as the series hybrid HPU. Hence, it was decided to build both a Gen 1-1 and Gen 1-2 mule vehicle to be able to fully and accurately determine the relative strengths and advantages of each engine technology when installed in an actual hybrid vehicle and under equivalent operating conditions. Unfortunately, the gas turbine HPU that was installed in the Gen 1-1 system mule vehicle never achieved a state of operational readiness that was sufficient to support the original testing and data collection mission that was intended for the Gen 1-1 system mule vehicle. The inability to operate the engine reliably enough to support the integration and test of the other associated hybrid propulsion system components and controls seriously delayed the progress of the program. Development and test of the Gen 1-1 vehicle was halted shortly after the beginning of Phase C, and the 


\section{FIGURE 9}

\section{Gen 1-1 Power Electronics Box}

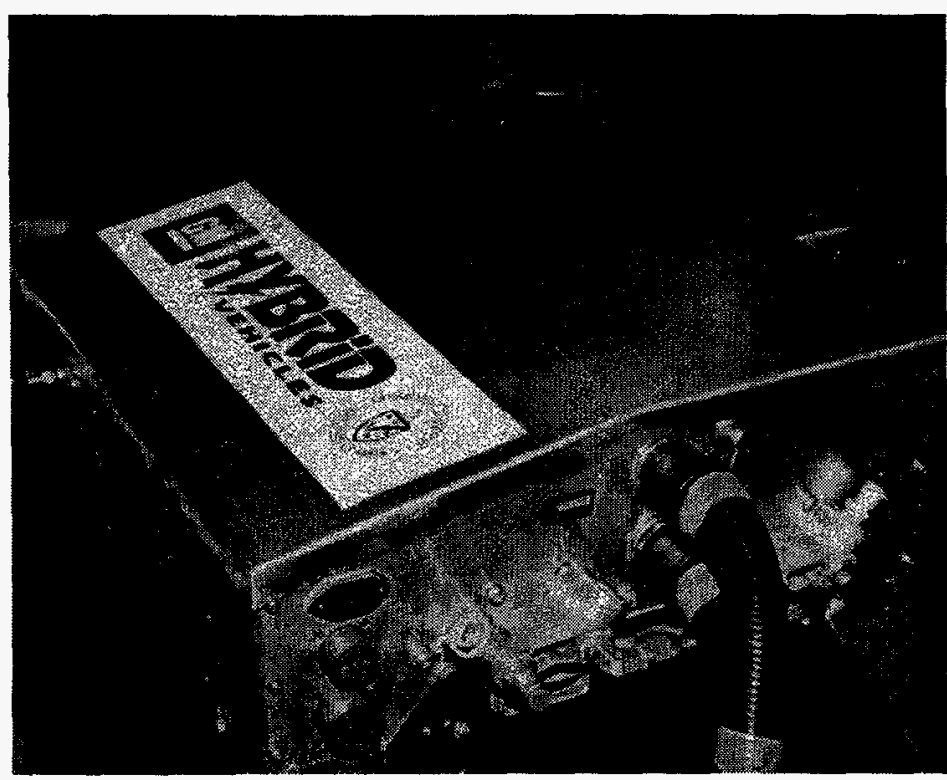

focus of the HPU development work shifted to the Stirling cycle engine and the Gen 1-2 system mule vehicle.

General Motors management terminated further devalopment efforts on the gas turbine HPU effective May 17, 1996. However, ceramic gas turbine technology is still considered to be a viable option as a hybrid vehicle HPU designed for $3 \mathrm{X}$ fuel economy and under circumstances where more time and resources are available for the development, test, and implementation of the essential enabling technology. A picture of the gas turbine HPU mated to the EDU and ready for installation in the Gen $1-1$ system mule vehicle is shown in Figure 10.

After cancellation of the gas turbine HPU, the program focused on the development of the Stirling cycle HPU. Through diligent engineering and small but important incremental

improvements to the engine configuration, this engine technology had gradually emerged as a strong candidate during fiscal year 1996. The engine developer had been conducting many parallel efforts at its own expense, or in support of other engine programs, which continued to mature the technology.

By the end of Phase B in March 1996, an engine and electrical generator had been built and separately tested. During Phase $\mathrm{C}$, the components were mated and test cell development of the complete HPU began. In parallel, a combustor test rig was constructed and used for developing the emissions control strategy. The first Stirling cycle HPU was delivered to General Motors in August of 1996. Initial operation of the engine in the Gen 1-2 system mule vehicle was achieved on September 20, 1996. Prior to delivery, the HPU ran successfully at $4,300 \mathrm{rpm}$ and generated $29 \mathrm{~kW}$ of electrical power in the supplier's test cell. At the rated speed of $5,600 \mathrm{rpm}$, the engine should come close to achieving its rated power level of $40 \mathrm{~kW}$. A picture of the Gen 1-2 Stirling HPU, mated to the EDU on the engine cradle, is shown in Figure 11.

Much additional development effort still remains on the Stirling HPU before this engine technology can be deemed to be "production feasible." The single largest technical hurdle yet to be overcome is the containment of the hydrogen working fluid. Work is underway to mitigate the loss of hydrogen through the heater tubes and slider seals. Advanced coating materials are being investigated and new, low friction, low loss seal designs are under consideration for further development.

By the end of fiscal year 1996, the engine was two-thirds of the way toward meeting its mass goal. Maximum power output achieved was

\section{Gas Turbine HPU Mated to EDU}

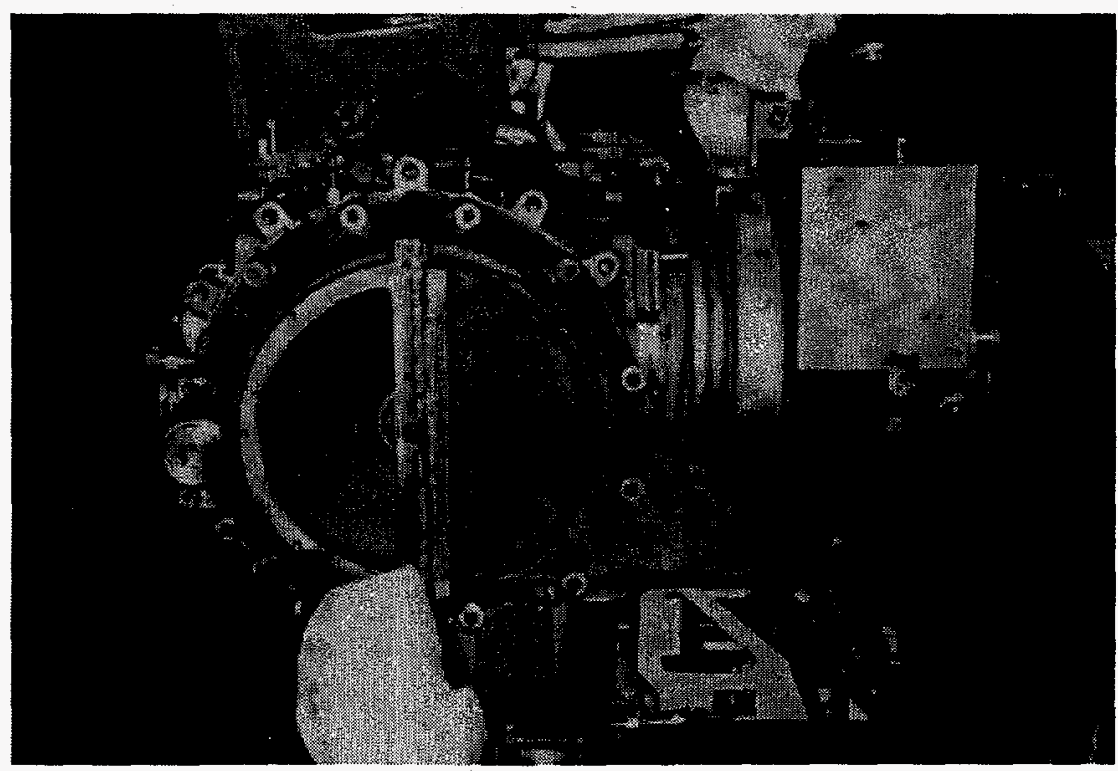




\section{FIGURE 11 \\ Gen 1-2 Stirling HPU Mated to EDU}

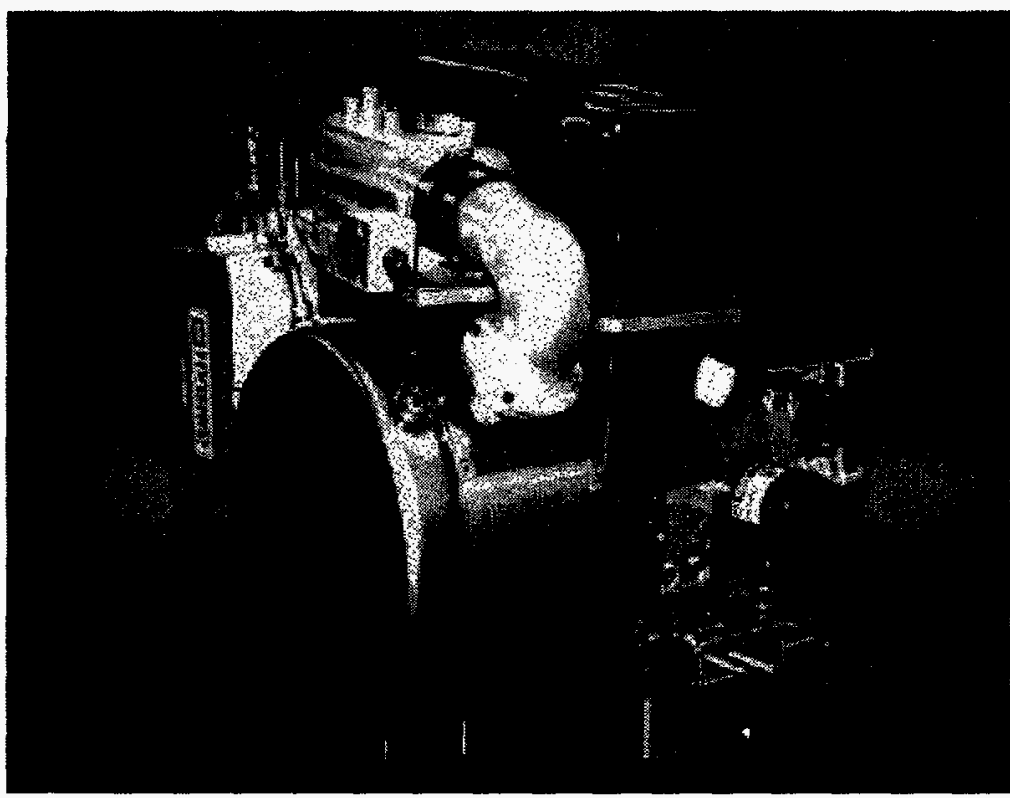

three-fourths of the target value. The engine's thermal efficiency was approximately $85 \%$ of the target value at its designated operating point. Emissions of hydrocarbon gases and carbon dioxide were well below target levels. However, NOx emissions remain a concern due to the elevated combustor temperatures; and a concerted effort will be undertaken during fiscal year 1997 to develop a NOx emissions reduction strategy.

\section{Energy Storage System Activities.}

Spiral-wound lead-acid battery technology was selected for use in this program due to its inherently high-power density, low cost, and demonstrated robustness in electric propulsion system applications. Much of the resources in this program allocated to the ESS have been devoted to making incremental improvements to battery performance and developing application-specific packaging for existing spiral-wound lead-acid battery technology.

A large amount of experimentation has been conducted at the battery pack supplier's facility to understand the factors affecting the performance and life of battery modules when subjected to the rigors of operation under a variety of hybrid vehicle duty cycles. A battery pack management system has been designed and implemented in an attempt to keep the individual modules within the battery pack at a balanced open circuit voltage. A battery pack cooling system was designed and implemented in an attempt to keep the temperatures of individual battery modules near constant and below the threshold temperature where damage can occur.

Individual spiral-wound lead-acid battery modules were tested to determine their ability to accept charge under various states-of-charge and ambient temperatures. Additional tests were run to determine selfdischarge characteristics and shelf life of the battery.

Experimental work on paste additives was conducted with the goal of achieving higher power and energy densities and increased cycle life. Cell level research is still underway on a variety of additives, some of which are showing considerable promise. An intricate computer model of the battery cell level thermal behavior was developed.

By the end of fiscal year 1996, the ESS had made significant progress toward achieving its technical targets. The mass of the pack was below its target level. Round trip energy efficiency is within two percentage points of the objective. Pack power is at $75 \%$ of the desired level. The propensity of these particular batteries to self-discharge remains a concern. Much work still must be done to reduce the estimated cost of battery packs at the projected levels of high-volume production.

\section{Fiscal Year 1996 Accomplishments (General Motors)}

- The Gen 1-1 system mule vehicle with a gas turbine HPU was completed. Due to inadequate performance, the gas turbine research and development activities were terminated. As a consequence of its high performance potential, the Stirling cycle engine was selected as the HPU technology of choice to meet the near-term program goal of $2 \mathrm{X}$ fuel economy. 
- Test cell development of the first Stirling cycle HPU was completed, and the unit was subsequently delivered to General Motors for installation in the Gen 1-2 system mule vehicle.

- All major propulsion system components were delivered for the Gen 1-2 system mule vehicle. Fit check of all the hybrid propulsion system components was completed, and the final assembly of the Gen 1-2 system mule vehicle was accomplished.

- The Gen 1-2 battery pack was completely redesigned to create more space in the passenger compartment. The Gen 1-2 spiral-wound lead-acid battery modules were improved to increase current carrying capability.

- The PEB was significantly improved to reduce its volume by $30 \%$ and reduce the cost of manufacturing and assembly.

\section{Ford Subcontract Activities}

\section{Introduction}

The Ford Motor Company hybrid vehicle development program is aimed at making advancements in automotive technology on a number of fronts. The Ford plan calls for a five-year program to analyze component trade-offs; identify hybrid propulsion systems and vehicle configurations; design, fabricate, and test components in mule vehicles; and to build and test hybrid prototype vehicles. This $50 \%$ costshared program began December 2, 1993 and is scheduled to end in December 1998.

The program objective is to design, build, and test production-feasible hybrid propulsion system technology with high energy efficiency and low emissions. Specific performance objectives include fuel efficiency twice that of a comparable production vehicle; driving range that is equivalent to current vehicles; and emissions below the most stringent Federal standard. The deliverable vehicles planned for the program include a Low Storage Requirement (LSR) parallel hybrid and a Post Transmission parallel hybrid vehicle. A series gas turbine vehicle that was under development is on hold until several programmatic issues are resolved.

The LSR hybrid has a minimal energy storage capacity of only $0.4 \mathrm{~kW}-\mathrm{hr}$. This results in a greatly reduced weight, size, and cost for the electric drive system, while still providing some benefits of hybridization. LSR hybrids will operate in a manner similar to conventional vehicles in most driving situations. The Post Transmission Hybrid (PTH) utilizes a much larger battery pack: approximately 2.0 $\mathrm{kW}$-hr. The term "post transmission" refers to the point at which the electric drive system's power assist enters the drivetrain; downstream of the transmission. The larger energy storage capacity in the PTH will allow greater flexibility in the control strategy, resulting in higher predicted fuel economy. This comes at a cost of higher vehicle weight and greater cost for the electric drive system.

Ford is employing a four-phase process that will facilitate the development of tailored, purpose-built propulsion system components for each of the vehicles that have been designed. To control costs, maximum use is also made of existing items that only require minor modification to meet the exacting specifications of the hybrid vehicle designs. Team members have defined performance targets that must be achieved in order for the hybrid system to meet its performance goals. Maximum use is being made of computer aided design, rapid prototyping, and concurrent engineering techniques to control costs and increase productivity. The four phases of the program and the major thrusts of each phase are identified below.

- Phase I - Study/Definition (Dec 1993 - Jun 1995): Characteristics of components and subsystems were defined and system trade-offs performed to understand the fundamental relationships between the major propulsion system components. In addition, hybrid propulsion systems and vehicle configurations were defined. 
- Phase II - System and Component Design (Jul 1995 - Oct 1996): The system design and the detailed component designs were generated. Acquisition of components for mule vehicles was initiated. Extensive computer modeling was used to gain a fundamental understanding of the control complexities, system management strategy, and control algorithms required for simultaneous operation of multiple power plants in a vehicle environment.

- Phase III - Component Build/Test (Oct 1996 - Dec 1997): All major propulsion system components are being built and tested. Vehicle control strategies are being fine tuned, the lightweight vehicle platforms are being fabricated, and the mule vehicles are under development and test.

- Phase IV - Systems Integration Vehicle Test (Jan 1998 - Dec 1998): The propulsion system components will be integrated into a total vehicle system, and the resulting vehicles will be tested to provide correlation to projections and demonstration of the technology.

In order to make hybrid vehicles more suitable for commercialization, there will have to be a considerable effort directed at developing several fundamental propulsion technologies. Therefore, several key enabling technologies are being evaluated in this program. Additional research and development of these key enabling technologies are required for future improvements in hybrid vehicle performance. Although improvements in power, efficiency, and mass reduction are desired for most components, cost remains the major challenge for virtually all. Because of the complex nature of hybrid propulsion systems and the number of discrete components that must be carefully integrated, the cost of each component will need to be reduced considerably before the system can become commercially viable. This is particularly true for batteries, power electronics, and hybrid power units. There are several ongoing activities outside this program that address these challenges. The key enabling technologies evaluated by Ford throughout 1996 include:

- High-power density energy storage devices (batteries, flywheels, ultracapacitors).

- Cost-effective high-efficiency power electronics and compact electric drive systems.

- Efficient, low-emission heat engines, including gas turbines and compression-ignition, directinjection (CIDI) diesel engines.

- Application of lightweight structural vehicle materials.

\section{Program Activities}

Throughout 1996, efforts were focused on completing detailed design of major components, fabricating prototype components, performing component tests, and validating the Phase I modeling assumptions. The work during this period was focused on the major components that are intended for the deliverable vehicles as well as enabling technology items such as ultracapacitors and flywheels. Much progress was made in the development of several critical propulsion system components: the CIDI power unit, gas turbine power units, and batteries. Tests were performed on individual battery cells, gas turbine combustor concepts, and the prototype flywheel system. Unfortunately, a motor failure curtailed the flywheel tests. The rotor and hub of the flywheel energy storage system is shown in Figure 12.

The lightweight materials applications project was also initiated during 1996 . This project aims to develop a lightweight, mid-size vehicle weighing approximately 2,000 lbs to serve as the platform for integrating the final hybrid propulsion system. In the systems analysis and modeling area, the vehicle configurations and control strategies for the two parallel vehicles was finalized, and additional vehicle modeling was accomplished to estimate and predict vehicle performance parameters. Modeling predictions showed both CIDI parallel vehicles meeting the program goal of $50 \mathrm{mpg}$. Although the series 
FIGURE 12

Flywheel Energy Storage System

Composite Rotor/Hub
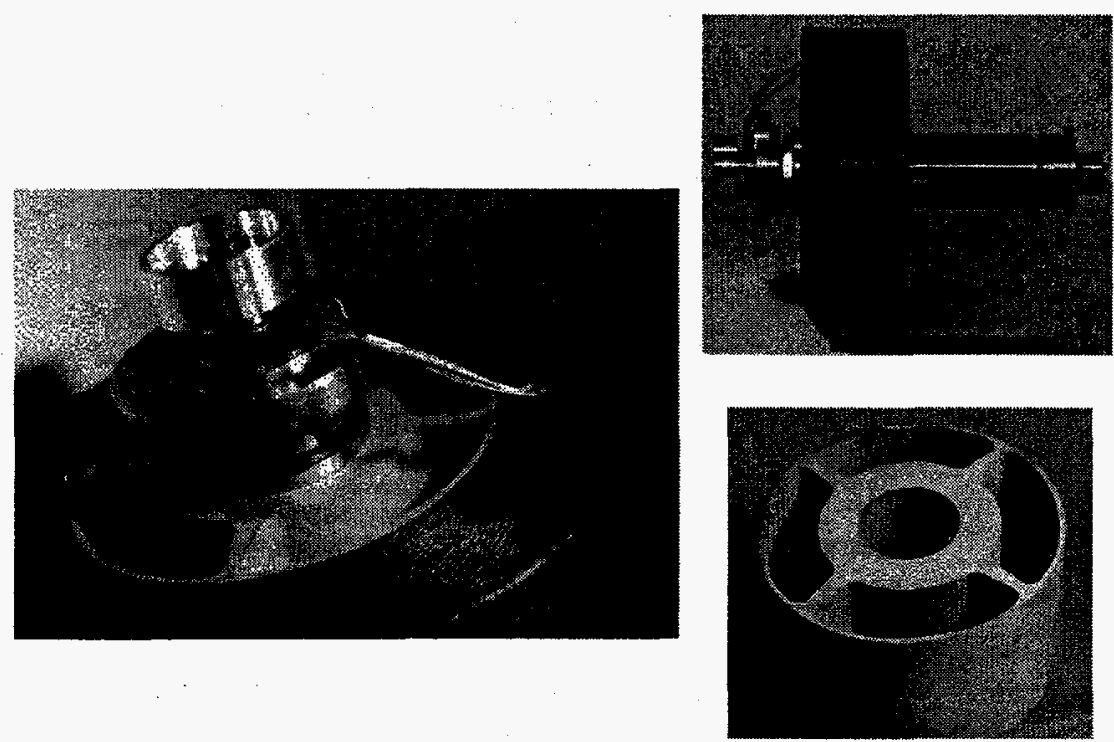

vehicle development was put on hold, work continued on development of the gas turbine power unit, which is important to the overall PNGV effort and potentially a very low emission alternative to the CIDI power unit. Figure 13 depicts the model 105-1 gas turbine hybrid power unit.

\section{Energy Storage. Several energy} storage devices were designed and developed. A $0.5 \mathrm{~kW}$-hr flywheel was constructed and tested during fiscal year 1996. The flywheel used low friction rolling element bearings, a permanent magnet motor/generator, and a polarwound composite rotor on a flex-rim hub. The unit was intended for demonstration purposes so a heavy gauge stainless steel containment housing ensured safety during tests.

During a full-power test, excessive temperatures in the upper structure caused the motor magnets to demagnetize. The failure put the flywheel program on hold until a reevaluation of the program could be conducted.

Two configurations of lead-acid battery have been under development: a bi-polar prismatic battery and a spiral-wound mono-polar battery. Only lead-acid batteries were considered viable for the program because of cost concerns and the immaturity of technology with other battery chemistries. Both batteries have the potential to provide the high specific power required for adequate vehicle performance. Considerable effort was aimed at optimizing the battery's thermal state and understanding its effect on battery life and performance. Several advanced techniques have been employed to measure the temperature distribution throughout full battery packs under different operating conditions. The bi-polar lead-acid battery is intended for the post-transmission hybrid, and the spiral-wound battery will be used in the low storage requirement hybrid. Both battery development efforts addressed manufacturing methods and cost reduction techniques as well.

FIGURE 13

Teledyne Ryan Aeronautical Model 105 Turbo-Generator Mockup

Hybrid Power Units. Two gas turbine power units have been under development. Both gas turbines include starter/generators and associated power electronics designed to provide $55 \mathrm{~kW}$ of electric power. The advantages of gas turbines in series hybrid vehicles include multi-fuel capability, low emissions, and operational flexibility. One of the gas turbines employs an all metal construction designed to be a low-cost, lowrisk approach. The other turbine employs ceramic components throughout the hot flowpath and is a more advanced approach. The use of ceramics reduces the weight of the engine and allows higher temperatures for

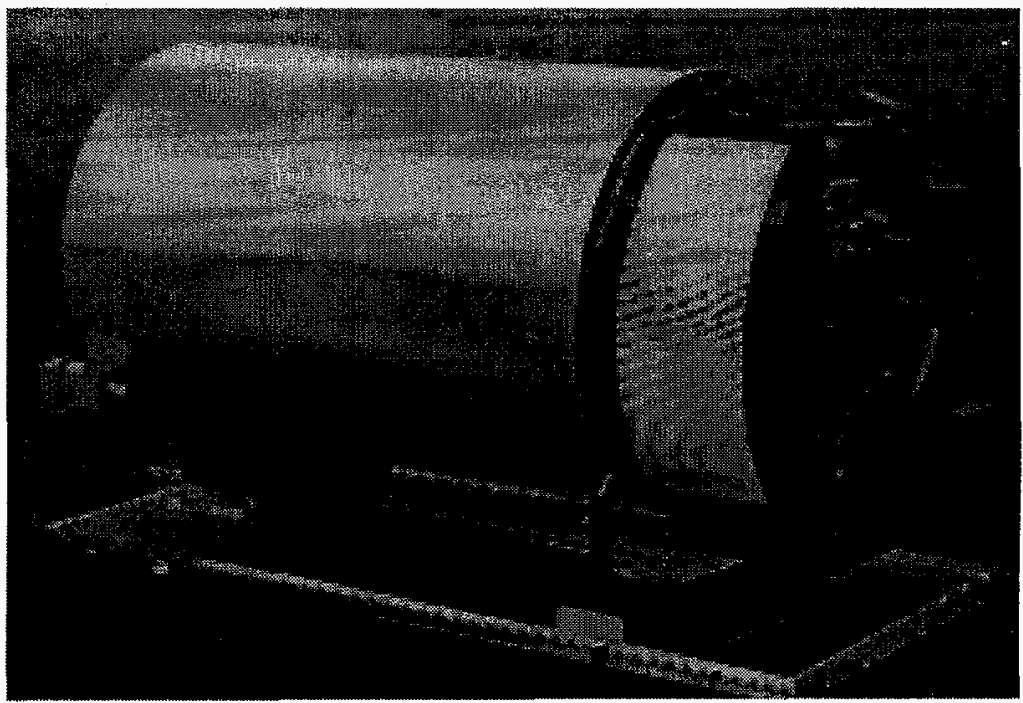
increased peak efficiency. 
A 1.2 liter $55 \mathrm{~kW}$ CIDI diesel engine was also under development. This unit will be among the most efficient small displacement diesel engines available, if it meets its performance targets. It has an allaluminum, through-bolted block and head, a turbocharger, and a high-pressure common rail fuel injection system. These technologies and extensive analytical techniques are being employed to reduce noise, vibration, and harshness to levels typical of gasoline engines. Emissions, driveability, reliability, and manufacturability also receive considerable attention. This engine will be suitable for conventional drivetrains as well as hybrid vehicles. This engine will be the power source for both the low storage requirement and PTH deliverable vehicles.

Vehicles. A lightweight materials application project was initiated in fiscal year 1996. The objective of this effort is to develop a prototype mid-size vehicle weighing approximately $2,000 \mathrm{lbs}$. This represents a $40 \%$ weight reduction relative to comparable conventional steel intensive vehicles. The vehicle makes extensive use of aluminum, magnesium, titanium, carbon fiber, and polymer composites. Each of the materials is utilized in the structural application, which maximizes mass reduction while minimizing cost and manufacturing process modifications. Two of the prototype vehicles will serve as the platforms for the two parallel vehicles in the program. This concept will be equally applicable to conventional vehicles as well.

Considerable effort was also directed at acquiring components for and beginning assembly of mule vehicles. These mule vehicles are conventional cars with the engine removed and replaced by a prototype hybrid propulsion system. Mules are very useful in gaining operational experience with prototype components, experimenting with different control strategies, working out packaging and integration details, and collecting operational data. The mule vehicles that were initiated during 1996 include: (1) a recuperated gas turbine powered series mule, based on the Ecostar electric vehicle, and (2) a gasoline engine powered parallel mule, based on a Mondeo vehicle platform. The traction drive unit utilized in the mule vehicles is shown in Figure 14. A description of the final deliverable vehicles is shown in Table 4.
FIGURE 14
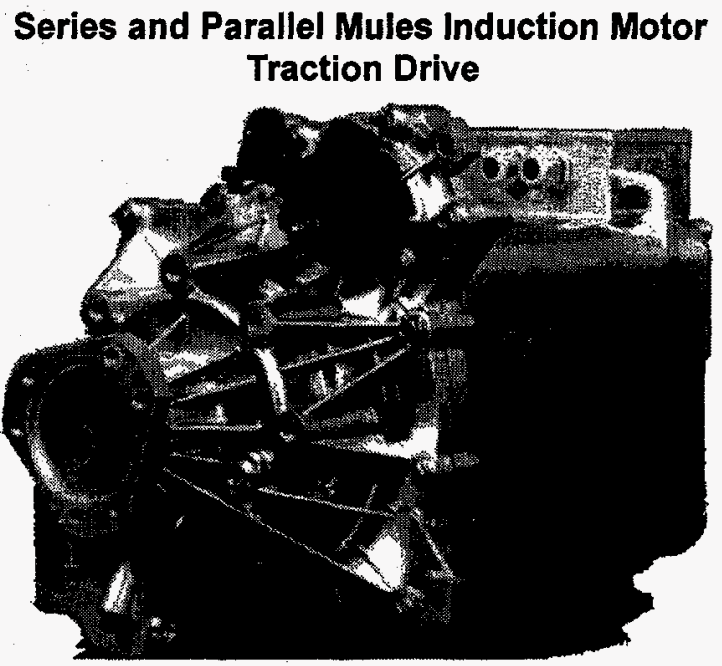

TABLE 4

Hybrid Vehicle Descriptions

\begin{tabular}{|c|c|c|c|}
\hline & Series & Post Transmission & Low Storage Requirement \\
\hline Platform & $\begin{array}{l}\text { 5+ Passenger, } \\
\text { Al-intensive Sedan }\end{array}$ & $\begin{array}{l}\text { 5-Passenger, Lightweight } \\
\text { Prototype }\end{array}$ & $\begin{array}{l}\text { 5-Passenger, Lightweight } \\
\text { Prototype }\end{array}$ \\
\hline HPU & $55 \mathrm{~kW}$ Turbo-Alternator & $55 \mathrm{~kW} 1.21 \mathrm{CIDI}$ & $55 \mathrm{~kW} 1.21 \mathrm{CIDI}$ \\
\hline Transmission & (none) & Auto 5-speed & Auto 5-speed \\
\hline Traction Motor & $75 \mathrm{~kW}$ EV Transaxle & $\begin{array}{l}\text { 18/30 kW Motor on } 4 \times 4 \\
\text { Transfer Case }\end{array}$ & $8 \mathrm{~kW}$ Starter/Alternator \\
\hline Battery & $180 \mathrm{~kW} \times 6 \mathrm{kWh}$ & $48 \mathrm{~kW} \times 2 \mathrm{kWh}$ & $15 \mathrm{~kW} \times 0.4 \mathrm{kWh}$ \\
\hline Weight (est.) & $1401 \mathrm{~kg}$ & $1258 \mathrm{~kg}$ & $1000 \mathrm{~kg}$ \\
\hline
\end{tabular}




\section{Fiscal Year 1996 Accomplishments (Ford Motor Company)}

- The System and Component Design Phase was completed and the phase report delivered.

- AlliedSignal completed development of a complete gas turbine hybrid power unit.

- Two configurations of high-power lead-acid battery cells were fabricated and tested.

- A single-cylinder CIDI research engine was built and tested to validate the concept for the full size CIDI HPU.

- The lightweight materials applications program began development of a lightweight, mid-size vehicle platform for the deliverable vehicles.

- The Mondeo-based gasoline, parallel mule vehicle was developed.

- Testing of an Ecostar-based series hybrid mule vehicle using an existing turbo generator was performed.

- Design, fabrication, and assembly of a $0.5 \mathrm{kWh}$ demonstration flywheel energy storage system was completed and tested.

\section{Chrysler Subcontract Activities}

\section{Introduction}

The Chrysler hybrid propulsion system development program began in March 1996 with the signing of a three-year, nine-month letter subcontract, 50-50\% cost shared with the Department of Energy. Although joining the HEV Program later than General Motors and Ford, Chrysler still plans to develop a viable hybrid propulsion system with the PNGV goals in mind. Since Chrysler began its program in March 1996, this report covers the first seven months of work, which has been mostly devoted to simulation studies and definitizing the subcontract. Chrysler's program includes propulsion hardware and software as well as those subsystems with substantial interface requirements and impact on energy efficiency.

The Chrysler program is divided into four phases:

- Concept Definition (Phase A)

- Design and Development (Phase B)

- Vehicle Integration (Phase C)

- Vehicle Demonstration (Phase D).

The program objective is to develop, build, test, and demonstrate a production-feasible hybrid propulsion system for use in a vehicle that provides a high-energy efficiency and low emissions. This propulsion system will incorporate advanced propulsion, control and energy storage technologies while meeting market requirements for cost, safety, and performance. An additional objective of this program is to develop alternative propulsion system technologies that would address and contribute to the goals set for the PNGV program.

The technical scope of this program includes propulsion hardware and software as well as those subsystems with substantial interface requirements that impact on energy efficiency and emissions. Modeling and simulation are pivotal analytical techniques in the program. Chrysler, in conjunction with the team members, is developing and improving models to predict the behavior of hybrid propulsion systems in order to build confidence in the analysis techniques, to reduce the design time. The validation 
of these models against a development vehicle helps speed the process toward a production vehicle, should the component technology prove successful.

Vehicle targets for this program are based on the assumption that the program will focus on powertrain propulsion technology and vehicle integration. Chrysler's hybrid propulsion system will be integrated in an aluminum Neon for test and development. However, since the PNGV target is a Concorde-size vehicle with the weight of a Neon, the ability to meet the PNGV targets must be extrapolated. The targets are compared in Table 5.

TABLE 5

Chrysler Hybrid Propulsion System Performance Targets

\begin{tabular}{|l|c|c|c||}
\hline Fuel economy (mpg) combined EPA cycle & 1996 Concord & Gen 2 Target. & PNGV Target \\
\hline Emissions (HC/CO NOx) @ 100K miles & 25.2 & up to 80 & up to 80 \\
\hline Accel 0-60 mph (sec) @ perf weight & $\begin{array}{c}0.25 / 3.4 / 0.4 \\
\text { Tier 1 }\end{array}$ & $\begin{array}{c}0.125 / 1.7 / 0.2 \\
\text { Tier 2 }\end{array}$ & $\begin{array}{c}0.125 / 1.7 / 0.2 \\
\text { Tier 2 }\end{array}$ \\
\hline Accel 0-85 (sec) @ perf weight & 11.4 & 12 & 12.0 \\
\hline Accel 40-60 (sec) @ perf weight & 22.9 & 24 & 23.4 \\
\hline Peak accel (ft/sec^2) @ perf weight & 5.4 & 6 & 5.3 \\
\hline Top speed (min) continuous (mph) @ perf weight & 16.6 & 16 & 17 \\
\hline $\begin{array}{l}\text { Max grade @ 55 mph (\%) for a 20-minute duration } \\
\text { with full accessory load @ gvw }\end{array}$ & $\begin{array}{c}8.8 \\
(3 \mathrm{rd} \mathrm{unlocked)}\end{array}$ & 6.5 & 85 \\
\hline Range (miles) & 450 & 380 & 6.5 \\
\hline \hline
\end{tabular}

\section{Program Activities}

During Phase A of the program, Chrysler performed a detailed engineering study of the relative merits of both series and parallel hybrid configurations. The focus of the seven months involved trade-off studies and performance predictions for numerous hybrid configurations and technologies. Based on simulation results, team member input, and Chrysler's automotive experience, Chrysler determined that a vehicle with minimal parallel hybridization is the optimum approach to meet the goal of this program and support PNGV goals. The powertrain consists of an advanced 3-cylinder turbo charged CIDI engine, advanced automatically shifted 5-speed manual transmission, a unique starter/alternator, advanced motor, and energy storage combination. Chrysler then generated the design specifications for this parallel configuration, which became identified as the Gen 1 design. The vehicle specifications are shown in Table 6.

The alternator and battery pack are sized to capture regeneration energy and return this energy to power only the accessories. The electric motor is not intended to drive the vehicle in forward gear, but will drive the vehicle in reverse gear, thereby eliminating the need for a reverse gear in the transmission, which helps reduce the transmission cost. Electronic shifting will be employed to automatically shift the 5-speed manual transmission.

Chrysler's HEV program will optimize this configuration through simulation and vehicle build, test, and development for the duration of the HEV program. This will be accomplished in three steps: Generation 0B, Generation 1, and Generation 2. These developmental test mules are described below. 
TABLE 6

Chrysler Gen 1 Prototype Vehicle Specifications

\begin{tabular}{|c|c|}
\hline Parameter: & Gen / Prototype Specifications \\
\hline Curb Weight (lbs) & 2,000 \\
\hline Performance Weight $(\mathrm{lbs})(\mathrm{curb}+300)$ & 2,300 \\
\hline Gross Weight (lbs) (curb $+1,000)$ & 3,000 \\
\hline Coefficient of Drag (cd) & 0.20 \\
\hline Frontal Area $\left(\mathrm{A} \mathrm{ft}^{2}\right)$ & 21.5 \\
\hline $\mathrm{CdA}\left(\mathrm{ft}^{2}\right)$ & 4.3 \\
\hline Tire Size & P195/60R15 \\
\hline Tire Rev/Mile & 866 \\
\hline Rolling Resistance Coefficient & 0.005 \\
\hline Wheel/Tire/Brake Rotor Inertia (slug $\mathrm{ft}^{2}$ ) & 0.75 \\
\hline Accessory Power (hp) & 1.0 \\
\hline Weight Distribution (front) & 0.62 \\
\hline Center of Gravity Height/Wheelbase & 0.2 \\
\hline
\end{tabular}

Gen OB. An important part of the program is an automatically shifted manual transmission for improved efficiency over a standard automatic transmission. The program direction is to use the electric motor to perform engine-transmission synchronization. Gen $\mathrm{OB}$ is a current production Neon with a 2.0 liter gasoline engine, with a 5-speed manual transmission mated to an existing powertrain. This test mule will be used for communications, control, and shift strategy development on this vehicle in preparation for the Gen 1 HEV build scheduled for July 1997.

Gen 1. For the first generation (Gen 1) of HEV components, this test mule, with existing state-of-the-art technology, will be used to help design and build components to primarily develop control strategies and software.

Gen 2. The second test mule will incorporate stretch technology in the designs of components and systems that have potential to reach production and be cost effective in the PNGV time frame. This design will incorporate advanced electric motor technologies such as permanent magnet, $\mathrm{AC}$ induction, synchronous reluctance or switched reluctance; advanced diesel engine technologies designed to achieve Tier 2 emission levels; an advanced alternator/starter/motor design; advanced transmission; advanced high-power energy storage system; advanced power electronics; and controllers.

\section{Fiscal Year 1996 Accomplishments (Chrysler Corporation)}

- Vehicle performance goals were developed.

- Preliminary component specifications were established.

- Simulation studies were completed defining the HEV configurations.

- Preliminary packaging was completed for the Gen 1 design. 


\section{HIGH-POWER ENERGY STORAGE DEVICES}

A lightweight, compact, high-power energy storage device is one of the critical pacing component technologies for a viable hybrid propulsion system. The primary functions of the device are to level the dynamic load profiles for the powertrain, to recover the energy from the regenerative braking systems, and to store unused engine output during braking and idle periods. Based on the hybrid vehicle requirements, detailed technical targets at the subsystems level have been developed for high-power energy storage supporting the 80-mpg objectives of the Vehicle Systems effort and the PNGV. Two sets of parallel targets have been developed for the fast-response and the slow-response engines (see Table 7). These targets cover requirements for power, energy, efficiency, cycle and calendar life, weight, volume, and cost as well as operating voltage, self-discharge, and temperature limits. These targets differ considerably from those for the high-energy electric vehicle batteries being developed (for a full electric vehicle rather than a hybrid) under the U.S. Department of Energy (DOE)-U.S. Advanced Battery Consortium (USABC) cooperative agreement (June 1991).

The critical need is to develop low-cost, high-power energy storage technology that meets or exceeds the desired energy storage requirements for the fast-response and slow-response engines. Candidate technologies that have the potential to meet or exceed these requirements are advanced high-power batteries for the slow-response engine, and ultracapacitors and flywheels for the fast-response engine. These technologies are the focus of the high-power energy storage activities.

\section{HIGH-POWER BATTERIES}

\section{Technology Background}

For the slow-response engine, the high-power battery storage requirements are significantly more challenging than those for electric vehicles. One major challenge is that the required power-to-energy ratio, a key determinant of battery cell design, is a factor of 10 greater for hybrid vehicles. A second major challenge is the need to operate the battery at an intermediate state-of-charge (SOC), such that it can both accept regenerative power input and deliver discharge power output. Typically, the battery will never be fully recharged, except as a possible periodic maintenance operation. A third unique challenge is very long cycle life in a pulsing mode, with relatively small swings in battery SOC. The target life is at least 120,000 cycles with a $3 \%$ change in SOC.

The greatest challenge will likely be to achieve the production cost goals for the energy storage system. Several manufacturing process challenges need to be addressed, involving fabrication and assembly of relatively thin electrodes at high throughput rates, assembly of electrodes into conventional or advanced bi-polar cells, and integration of cells into physical modules and complete systems.

Two candidate battery chemistries that have the potential to meet these challenges are nickel-metal hydride and lithium-ion. The first of these offers relatively good power capability due to the good ionic conductivity of the potassium hydroxide electrolyte. The second offers better energy density, but may require excessively thin electrodes to meet the power targets.

\section{Program Activities}

Under a 50-50\% cost shared Cooperative Agreement signed in September 1995 with DOE, the USABC is investigating both nickel-metal hydride and lithium-ion technologies. The objective is first to establish the basic performance and life capabilities in small laboratory cells, and then to demonstrate the best of these technologies in full-size modules. The USABC has issued four Phase I subcontracts to establish baseline cell chemistries and electrode design parameters. SAFT America and SRI International were awarded contracts to develop the lithium-ion technology; Yardney Technical Products and VARTA AG 
were awarded contracts for developing the nickel-metal hydride technology. The SAFT contract was completed in August 1996.

TABLE 7

Energy Storage Requirements for Hybrid Vehicles

\begin{tabular}{|c|c|c|c|c|c|}
\hline \multirow{3}{*}{ 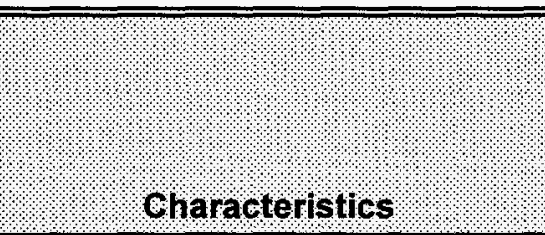 } & \multirow[b]{3}{*}{ Units } & \multicolumn{4}{|c|}{ Targets } \\
\hline & & \multicolumn{2}{|c|}{ rast-Response Engine } & \multicolumn{2}{|c|}{ Slow Response Engline } \\
\hline & & Minimum & Desired & Minimum & Desired \\
\hline $\begin{array}{l}\text { Pulse Discharge Power (constant for } \\
18 \text { seconds) }\end{array}$ & $\mathrm{kW}$ & 25 & 40 & 65 & 80 \\
\hline $\begin{array}{l}\text { Peak Regenerative Pulse Power } \\
\text { (trapezoidal pulse for } 10 \text { seconds } \\
\text { for the specified pulse energy) }\end{array}$ & $\mathrm{kW}$ & $\begin{array}{c}30 \\
\text { (for } 50-\mathrm{Wh} \\
\text { pulse) } \\
\end{array}$ & $\begin{array}{c}60 \text { to } 110 \\
\text { (for } 150-\mathrm{Wh} \\
\text { pulse) }\end{array}$ & $\begin{array}{c}70 \\
\text { (for } 150-\mathrm{Wh} \\
\text { pulse) } \\
\end{array}$ & $\begin{array}{c}150 \\
\text { (for } 150- \\
\text { Wh pulse) } \\
\end{array}$ \\
\hline $\begin{array}{l}\text { Total Available Energy (discharge } \\
\text { plus regenerative) }\end{array}$ & $\mathrm{kWh}$ & 0.3 & 0.5 to 0.75 & 3 & 3 to 8 \\
\hline $\begin{array}{l}\text { Minimum Round-trip Efficiency on } \\
\text { FUDS/HWFET Cycle* }\end{array}$ & $\%$ & 90 & 90 & 95 & 95 \\
\hline $\begin{array}{l}\text { Cycle Life, for Specified SOC } \\
\text { Increments }\end{array}$ & & $\begin{array}{l}200 \mathrm{~K} \text { for } \\
25 \mathrm{Wh} \\
50 \mathrm{~K} \text { for } \\
100 \mathrm{Wh} \\
\end{array}$ & $\begin{array}{l}300 \mathrm{~K} \text { for } \\
35 \mathrm{Wh} \\
100 \mathrm{~K} \text { for } \\
100 \mathrm{Wh} \\
\end{array}$ & $\begin{array}{l}120 \mathrm{~K} \text { for } \\
100 \mathrm{Wh} \\
20 \mathrm{~K} \text { for } \\
600 \mathrm{Wh}\end{array}$ & $\begin{array}{l}300 \mathrm{~K} \text { for } \\
200 \mathrm{Wh} \\
100 \mathrm{~K} \text { for } \\
600 \mathrm{Wh} \\
\end{array}$ \\
\hline Calendar Life & year & 10 & 10 & 10 & 10 \\
\hline $\begin{array}{l}\text { Maximum Weight (plus marginal } \\
\text { increase/kWh for } \mathrm{E}>3 \mathrm{kWh})^{* *}\end{array}$ & $\mathrm{~kg}$ & 40 & 35 & $\begin{array}{r}65 \\
(+10 \\
\mathrm{kg} / \mathrm{kWh}) \\
\end{array}$ & $\begin{array}{c}50 \\
(+10 \\
\mathrm{kg} / \mathrm{kWh}) \\
\end{array}$ \\
\hline $\begin{array}{l}\text { Maximum Volume (plus marginal } \\
\text { increase } / \mathrm{kWh} \text { for } \mathrm{E}>3 \mathrm{kWh} \text { ) }\end{array}$ & 1 & 32 & 25 & $\begin{array}{c}40 \\
(+81 / \mathrm{kWh}) \\
\end{array}$ & $\begin{array}{c}40 \\
(+81 / \mathrm{kWh}) \\
\end{array}$ \\
\hline Maximum Package Height & $\mathrm{mm}$ & 150 & 150 & 150 & 150 \\
\hline $\begin{array}{l}\text { Production Cost, at } 100,000 \text { Units } \\
\text { Per Year (plus marginal } \\
\text { increase } / \mathrm{kWh} \text { for } \mathrm{E}>3 \mathrm{kWh} \text { ) }\end{array}$ & $\$$ & 300 & 200 & $\begin{array}{c}500 \\
(+\$ 62.50 / \mathrm{k} \\
\mathrm{Wh}) \\
\end{array}$ & $\begin{array}{c}500 \\
(+\$ 62.50 / k \\
\text { Wh }) \\
\end{array}$ \\
\hline Operating Voltage Limits & vdc & $\begin{array}{l}300 \min \\
400 \max \end{array}$ & $\begin{array}{l}300 \min \\
400 \max \end{array}$ & $\begin{array}{l}300 \min \\
400 \max \\
\end{array}$ & $\begin{array}{l}300 \min \\
400 \max \\
\end{array}$ \\
\hline $\begin{array}{l}\text { Maximum Allowable Self-discharge } \\
\text { Rate }\end{array}$ & $\begin{array}{l}\text { Wh/ } \\
\text { day }\end{array}$ & 50 & 50 & 50 & 50 \\
\hline $\begin{array}{l}\text { Temperature Range: } \\
\text { Equipment Operation } \\
\text { Equipment Survival } \\
\end{array}$ & ${ }^{\circ} \mathrm{C}$ & $\begin{array}{l}-40 \text { to }+52 \\
-46 \text { to }+66 \\
\end{array}$ & $\begin{array}{l}-40 \text { to }+52 \\
-46 \text { to }+66\end{array}$ & $\begin{array}{l}-40 \text { to }+52 \\
-46 \text { to }+66\end{array}$ & $\begin{array}{l}-40 \text { to }+52 \\
-46 \text { to }+66 \\
\end{array}$ \\
\hline
\end{tabular}

* $\quad$ FUDS $=$ Federal Urban Driving Schedule

HWFET = Highway Fuel Economy Test

** $\mathrm{E}=$ Total Available Energy 
In conjunction with the Phase I cell programs, the USABC has developed battery technology analysis models and test protocols tailored for the PNGV high-power battery applications. The analysis models include a generic unit cell model to support interpretation of experimental results, and a battery system design model that optimally scales up the unit cell data to a full system. New test protocols have been developed for performance characterization and pulse cycle life at varying magnitudes of the cyclic swing in battery SOC. These will be used by INEL to evaluate the deliverable cells from the four Phase I subcontractors.

\section{Fiscal Year 1996 Accomplishments}

- SAFT demonstrated specific power of up to $2,000 \mathrm{~W} / \mathrm{kg}$ and specific energy greater than $60 \mathrm{Wh} / \mathrm{kg}$ at the unit cell level (electrodes, substrates, separator, and electrolyte).

- SAFT achieved cycle life in excess of 120,000 cycles at an SOC increment of $3 \%$ of rated capacity, with less than $20 \%$ degradation in performance.

- $\quad$ SAFT delivered four optimized laboratory cells (Figure 15) to Idaho National Engineering Laboratory (INEL) for confirmation test and evaluation.

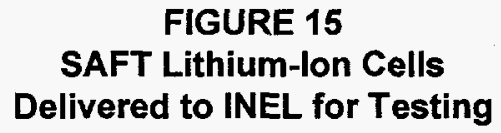

\section{ULTRACAPACITORS}

\section{Technology Background}

Electrochemical capacitors (ultracapacitors) are being developed for hybrid vehicle systems as a power-assist device for the fast-response engine energy storage requirements. Ultracapacitors show promise toward being able to accept high regenerative pulses while exhibiting high cycle life. However, before ultracapacitors can achieve widespread use, there are several technical barriers that need to be resolved: low specific energy, high cost, low reliability in a multiple string configuration, and efficient packaging of multi-cell high-voltage modules.

Carbon (particles, fibers, foams, and composites) has been investigated extensively and formed into electrodes exhibiting high specific capacity (100 to $300 \mathrm{~F} / \mathrm{g}$ ) and low electronic resistivity $(0.01 \mathrm{ohm}-\mathrm{cm})$. Packaged experimental carbon-based devices have achieved $5 \mathrm{Wh} / \mathrm{kg}$ and $1 \mathrm{~kW} / \mathrm{kg}$. Although these values are impressive, the volumetric energy density is low and the high cost of these devices may prohibit their widespread use as a component in hybrid propulsion systems. Alternative non-carbon based systems are being investigated because of the potential for low cost while meeting the energy storage requirements shown in Table 7. These include dielectric nano-structure materials, conducting polymers, and metal oxides in combination with aqueous or organic electrolytes.

\section{Program Activities}

The DOE ultracapacitor program supports several industrial as well as national laboratory development projects aimed at developing the technology to produce ultracapacitors with specific energy greater than $5 \mathrm{Wh} / \mathrm{kg}$ and specific power greater than $1,000 \mathrm{~W} / \mathrm{kg}$. INEL is responsible for technical program management, technology assessment, and testing. 


\section{Fiscal Year 1996 Accomplishments}

- Demonstrated a three-cell carbon/organic ultracapacitor containing $200 \mathrm{~cm}^{2}$ bipolar electrodes at Maxwell Laboratories. Performance levels approached $5 \mathrm{Wh} / \mathrm{kg}$ at discharge powers of $600 \mathrm{~W} / \mathrm{kg}$ over a 3-Volt operational window.

- Developed carbon/aqueous based capacitors containing novel high-density Z-axis carbon electrodes at Federal Fabrics-Fibers. These cells are the highest energy aqueous based cells tested to date with $3 \mathrm{Wh} / \mathrm{kg}$ and $500 \mathrm{~W} / \mathrm{kg}$.

- Demonstrated a potentially low-cost fabrication method for forming thin sol-gel nickel oxide electrodes for aqueous based electrochemical capacitors at the University of Wisconsin.

- Activated a class-100 clean room facility for fabricating dielectric nano-structure capacitor at Lawrence Livermore National Laboratory (LLNL). High-rate deposition suitable for large-scale manufacturing was demonstrated.

\section{FLYWHEELS}

\section{Technology Background}

Chrysler, Ford, and General Motors have completed preliminary work on the development of flywheel system technologies for automotive applications. The major issue that must be resolved prior to the use of flywheels is safety and containment in the event of a failure of the flywheel rotor. Other issues identified are weight of the containment system, cost of the composite materials, and the development of effective magnetic or mechanical bearings.

\section{Program Activities}

A coordinated program involving DOE and the Defense Advanced Research Projects Agency (DARPA) has been initiated, with emphasis on addressing safety and containment. Through the Oak Ridge National Laboratory (ORNL) and the LLNL research and development activities, DOE's efforts are focused on the development of analytical models and design tools. These development efforts will assist the flywheel industry in the design and development of lightweight containment housings. In support of this effort, the DARPA-funded flywheel developers are building hardware and test fixtures and conducting experimental rotor burst tests.

\section{Fiscal Year 1996 Accomplishments}

- Developed a kinetic particle model that will be used to predict actual experimental results and to guide experiments that will adequately support completion of the model development.

- Demonstrated use of the transient dynamic model for containment housing design. This modeling activity has improved the understanding of the importance of mass, stiffness, and damping with respect to how these parameters would be used in a housing design.

- Prepared a draft industry safety memo (test protocol). The memo describes possible flywheel rotor failure modes and seeks to make all flywheel developers aware of some of the unexpected failure characteristics. 


\section{POWER ELECTRONICS AND ELECTRIC MACHINES}

\section{TECHNOLOGY BACKGROUND}

The next generation of electric-drive vehicles will require increasing use of sophisticated power electronics for the intelligent control and conditioning of all electric power. In a hybrid electric vehicle, power electronics must be provided for power system control management, bi-directional traction drive, power generation DC-DC converter, auxiliary motor drives, and other subsystems. An order of magnitude cost reduction is needed along with dramatic improvements in weight, volume, performance, reliability, and efficiency. Power Electronic Building Block (PEBB) technology, under development through a joint DOE/Navy-industry Program, offers the potential for achieving the needed improvements in power electronics. These improvements can be applied to automotive and military applications and to a wide range of other industrial uses.

The overall PEBB Program goal is to develop new technology that will dramatically reduce the cost and weight of the electric propulsion system and its high-power accessories, while adding a high degree of functional integration, and maintaining high efficiency and reliability for automotive industry applications. Specific technology objectives are aimed at:

- Cost Reduction: Today's motor controller technology is too expensive, costing as much as, or more than, the entire conventional ICE powertrain at $\$ 2,500$. This is a major obstacle to achieving viable electric and hybrid vehicles, comparable in many ways to the lack of adequate battery technology. For the power electronics system (inverter/controller), the target is to reduce cost from the current $\$ 50 / \mathrm{kW}$ to $\$ 2 / \mathrm{kW}$ by 2004 (PNGV timeframe).

- Weight and Volume Reduction: Weight and volume are critical to vehicle design for achieving efficient packaging and fuel savings. This is particularly true for hybrid vehicles because more components are combined into the limited space under the hood. Current power electronics technology is bulky and heavy, with off-the-shelf $100-\mathrm{kW}$ units that are the size of a large suitcase and weighing nearly $70 \mathrm{lbs}$. By integrating power circuits, bus structures, cooling and control circuits, and other technology advancements, the PEBB Program seeks to downsize $100-\mathrm{kW}$ units that are to be under $10 \mathrm{lbs}$ and one-fourth of a cubic foot.

- Improved Functional Integration: Integrated power technology products with a high degree of functional integration will drastically simplify system design while reducing weight and volume. Advanced PEBB technologies under development will integrate control, communications, bus work, cooling, and improved power electronics.

- Efficiency Improvement: Efficiency is key to reducing vehicle energy requirements and component-level thermal management requirements. The PEBB Program is targeting $98 \%$ efficiency for the power electronics system (inverter/controller) by 2004 , up from the $94 \%$ efficiency currently achievable.

Several technical barriers must be addressed in order to achieve these technology objectives. Improvements are required in the areas of (1) materials technology, (2) thermal management, and (3) miniaturization and optimization. Materials that allow high-temperature operation with high-power densities are needed. New thermal management technologies are needed to dissipate the heat and ultimately remove it from the module. Power electronics components are not adequately miniaturized or optimized. Each power device, for example, needs an isolated power supply for control, which multiplies system complexity and cost. Integration of these components is needed to reduce cost, size, and weight. Large power systems also need fast communications and control features to prevent power faults and to perform system-level control. To support this, power system communication and control 
standards need to be developed. These standards also will help to reduce costs by increasing commonality between components.

\section{PROGRAM ACTIVITIES}

DOE and the Office of Naval Research initiated the joint PEBB Program in 1995 to develop advanced power electronics technologies for use in automotive, defense, and other industrial applications. A high degree of similarity has been identified between the power systems requirements for these applications. The PEBB Program leverages available government funding and technical expertise at the national laboratories and universities through a concurrent engineering program with industry.

Harris Semiconductor is the prime industry contractor for the PEBB Program. Systems-level development and demonstration of the PEBB technology is done at the Oak Ridge Power Electronics Center in Oak Ridge, TN and the Naval Surface Warfare Center in Annapolis, MD. DOE is currently defining a baseline automotive controller with representatives from Chrysler Liberty (a division of Chrysler), Ford, and General Motors.

\section{FISCAL YEAR 1996 ACCOMPLISHMENTS}

- Demonstrated trench technology (micron-size grooves in semiconductor structure) for improved power density switches at Harris Semiconductor and the Naval Research Laboratory.

- Conducted functional demonstration of PEBB technology -- one integrated device can control a motor, an actuator, DC-DC conversion, and a low-noise, three-phase power supply.

- Demonstrated a $100 \mathrm{~kW}$ soft-switching, multi-function motor controller at ORNL.

\section{ADVANCED VEHICLE COMPETITIONS}

Advanced vehicle competitions are an effective way to integrate all the technologies necessary for efficient, proof-of-concept vehicles. The competitions produce a wide range of results that allow industry to quickly assess the merits of a number of innovative concepts.

In fiscal year 1996, DOE discontinued the Hybrid Electric Vehicle Challenge and introduced two new competitions: the FutureCar Challenge and the Propane Vehicle Challenge.

FutureCar, the most ambitious competition ever offered by DOE, is co-sponsored by the U.S. Council for Automotive Research, representing Chrysler, Ford, and General Motors. The competition is closely aligned with the technology path of the PNGV. Twelve universities were selected to participate in the first two-year phase of the FutureCar Challenge. Each school was given a mid-size production vehicle and $\$ 10,000$ in seed money from the auto manufacturers. The objective of FutureCar, like PNGV, is to design and build a vehicle that can ultimately get up to $80 \mathrm{mpg}$ without sacrificing the performance, safety, and affordability of the original car. Technologies used to reach this goal included: CIDI engines, both parallel and series hybrid configurations, high-power energy storage, power electronics, lightweight vehicle materials, and alternative fuels (electricity, ethanol, natural gas, and propane). In the FutureCar event, which occurred at the Ford Proving Grounds in June 1996, Virginia Polytechnic Institute showed that a mid-size production vehicle could be modified to exceed conventional fuel economy by achieving a combined city/highway fuel economy of $44.7 \mathrm{mpg}$. Lawrence Technological University won awards for best use of advanced technology and best engineering design (see Figure 16).

In the Propane Vehicle Challenge, co-sponsored by Natural Resources Canada, Chrysler Canada, and DOE, 12 universities converted a Chrysler minivan to dedicated propane operation. The objective was to demonstrate performance that equaled that of the gasoline counterpart. The schools incorporated both gaseous and liquid injection technologies. Although no one school met or exceeded the performance of a 


\section{FIGURE 16 \\ Lawrence Technological University 1996 FutureCar Challenge Hybrid Electric Vehicle}

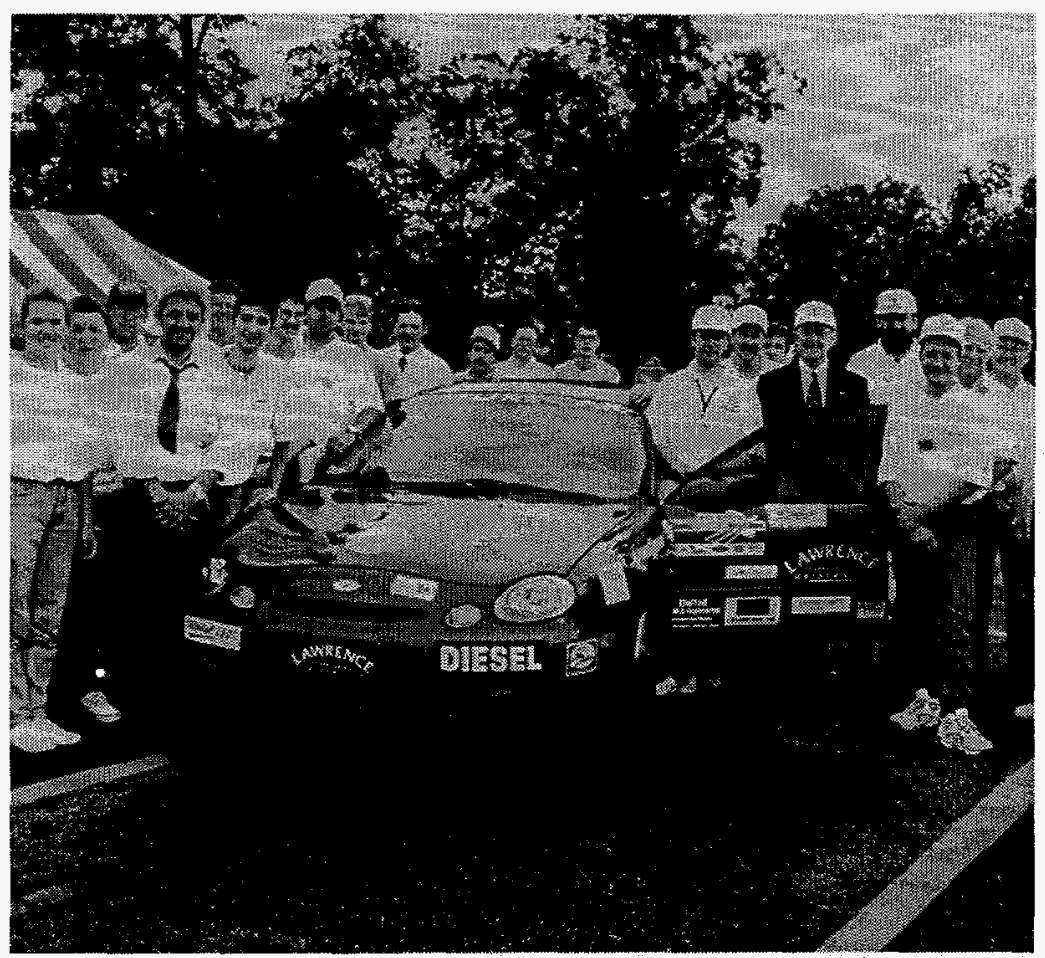

stock vehicle in all areas, there were many outstanding achievements. For instance, the University of Windsor met ULEV emissions (two other schools met low-emission vehicle emission levels), the Illinois Institute of Technology achieved on-road fuel economy of $20.2 \mathrm{mpg}$, and Texas Tech demonstrated acceleration and handling that was faster than the standard minivan.

\subsection{ADVANCED HEAT ENGINES}

\section{INTRODUCTION}

The function of the Advanced Heat Engines Research and

Development Program is to conduct research and development of advanced heat engine and complete power unit technologies that will contribute to revolutionary improvements in the fuel efficiency and emission characteristics of light-duty vehicles. The program consists of three key activities: (1) Gas Turbine Hybrid Power Unit (GT-HPU) research and development, (2) Advanced Automotive Piston Engine research and development, and (3) Combustion Efficiency and Emissions research and development. The Advanced Heat Engines Program is working closely with the major domestic gas turbine manufacturers, automobile manufacturers, diesel engine manufacturers, suppliers, national laboratories, and universities to identify, evaluate, and accelerate development of the most promising technology alternatives to a point where industry can proceed with their commercialization in production engines. Fiscal year 1996 Advanced Heat Engines Research and Development Program participants, contracting mechanisms, and cost share percentages are shown in Table 8. Successful development and commercialization of advanced heat engine technologies for light-duty vehicles will directly contribute to reducing the Nation's petroleum dependency and alleviating adverse human health effects associated with exhaust emissions, while enhancing the competitiveness of the U.S. light-duty vehicle industry. The Advanced Heat Engines Research and Development Program is consistent with the requirements of the Energy Policy Act of 1992 (sections 2022 and 2025) and directly supports the goals of the Partnership for a New Generation of Vehicles (PNGV).

\section{GAS TURBINE HYBRID POWER UNIT}

Automotive-scale (20-60kW) gas turbine technology is being developed for a high-efficiency, ultra-low emission, and multi-fuel capable Hybrid Power Unit (HPU) as an option for PNGV. Use of ceramic components, with their high-temperature capability, is being pursued to increase gas turbine fuel efficiency (over metal components) while preserving and enhancing the low-emission characteristics. The fuel efficiency and emissions potential of a hybrid vehicle using a ceramic gas turbine power unit is illustrated in Figure 17. 
TABLE 8

Advanced Heat Engines

Fiscal Year 1996 Program Participants

\begin{tabular}{|c|c|c|}
\hline Particlpant organization & Mechanism & cost Share $(\%)$ \\
\hline \multicolumn{3}{|c|}{ Gas Turbine Hybrid Power Unit Research and Development (Technology Support) } \\
\hline NASA Lewis Research Center & Interagency Agreement & 0 \\
\hline Allison Engine Company & Contract & 20 \\
\hline Argonne National Laboratory & Task Assignment & 0 \\
\hline AlliedSignal Engines & Contract & 30 \\
\hline \multicolumn{3}{|c|}{ Advanced Automotive Piston Engine Technologies Research and Development } \\
\hline Argonne National Laboratory \& USCAR's LEP* & CRADAs** & 50 \\
\hline Idaho National Engineering Laboratory \& USCAR's LEP & CRADAs & 50 \\
\hline Oak Ridge National Laboratory \& USCAR's LEP & CRADA & 50 \\
\hline Pacific Northwest National Laboratory \& USCAR's LEP & CRADAs & 50 \\
\hline Sandia National Laboratories \& USCAR's LEP & CRADA & 50 \\
\hline \multicolumn{3}{|c|}{ Combustion Efficiency and Emissions Research and Development } \\
\hline Princeton University & Grant & 0 \\
\hline Florida A\&M University & Grant & 0 \\
\hline Massachusetts Institute of Technology & Grant & 0 \\
\hline Pennsylvania State University & Grant & 0 \\
\hline University of Illinois & Grant & 0 \\
\hline Drexel University & Grant & 0 \\
\hline
\end{tabular}

* U.S. Council for Automotive Research (USCAR) Low Emission Partnership (LEP) is composed of Chrysler, Ford, and General Motors.

** CRADA $=$ Cooperative Research and Development Agreement

\section{TECHNOLOGY BACKGROUND}

Metallic automotive gas turbines have achieved thermal efficiencies up to $30 \%$ with uncooled metal turbine engines operating up to $1,900^{\circ} \mathrm{F}$. Ceramic components permit turbine inlet temperatures up to $2,500^{\circ} \mathrm{F}$, increasing efficiency by $30 \%-40 \%$. Several experimental gas turbine engines using hightemperature ceramic components have been run for a cumulative-combined total of approximately 20,000 hours. A ceramic turbine rotor, the critical hot-section component, has been run 1,000 hours cumulative in realistic operation of a test-bed engine at $2,500^{\circ} \mathrm{F}$ inlet temperature. 


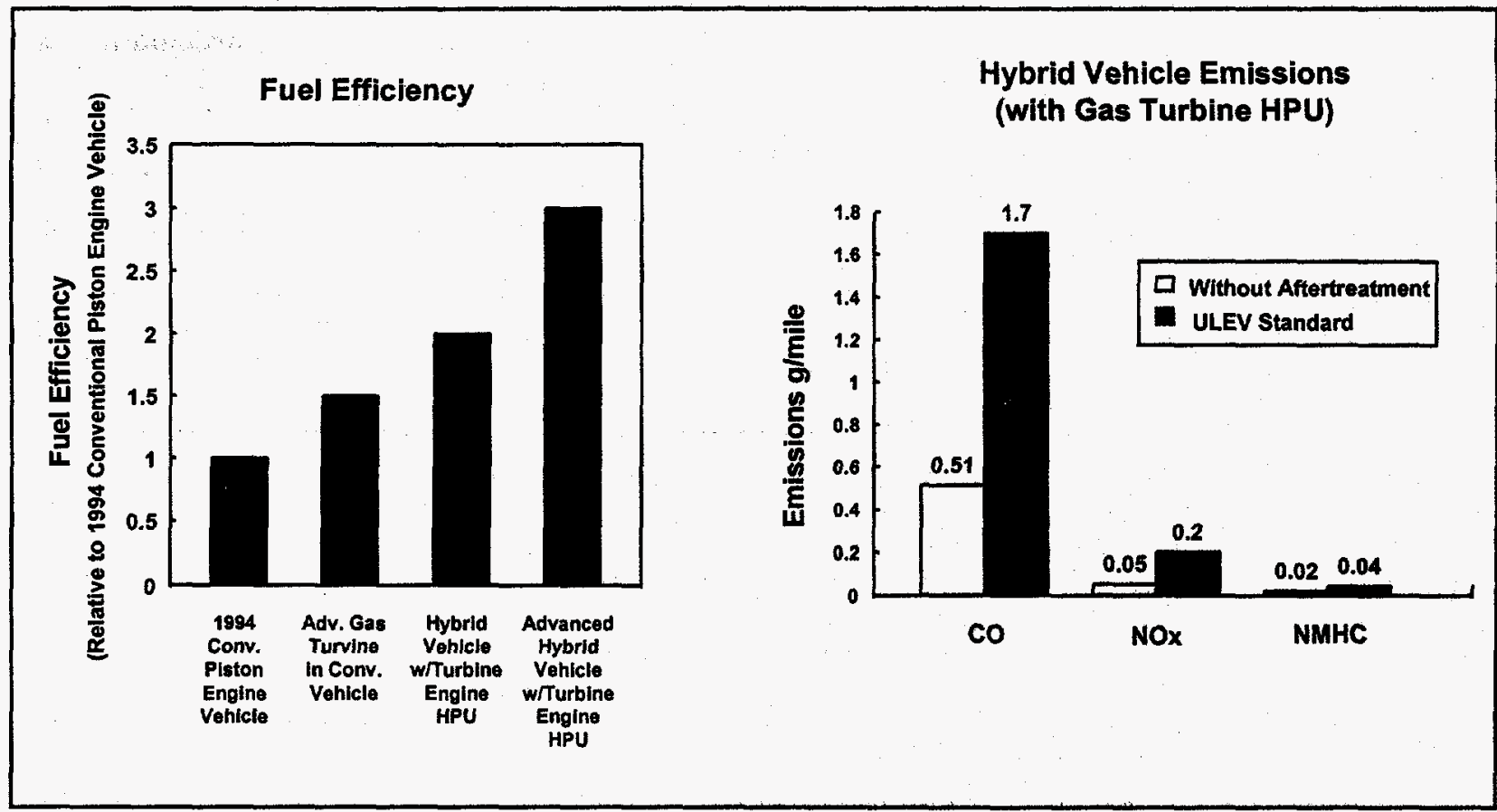

Development efforts for structural ceramics have focused on increasing strength and toughness, and improving forming processes. Major advances have been made in mechanical properties of several ceramic materials. However, complex-shaped components have not been manufactured from these materials on a large scale and they are still too costly. Current experimental ceramic fabricating processes produce net yields ranging from less than $40 \%$ to nearly $70 \%$. Net yield is defined as the percentage of manufactured parts that meet specifications relative to the total number of parts produced. In most cases, ceramic hardware received by engine companies did not meet all dimensional and quality specifications, indicating unresolved problems with design and manufacture of components.

Gas turbines with high-temperature heat recovery systems are currently in use for industrial applications. Low cost, commercially-manufactured automotive regenerators or recuperators are not currently available. Regenerator seals are limited by oxidation, high wear and friction, and chemical reactivity at higher temperatures. Seals with 10,000 -hour durability in a metal engine (operating at up to $1,900^{\circ} \mathrm{F}$ ) have been demonstrated in the laboratory. Continued advances have been made in materials and process development for high-temperature insulation and thermal management. Improved material density, lower conductivity, and improved surface finishes suitable for high-temperature ceramic turbines have been demonstrated. Experimental gas turbines and test rigs with advanced combustors have demonstrated the ability to meet all existing and proposed emission standards without exhaust aftertreatment. Automotive-turbine combustion systems have been demonstrated using gasoline, diesel and alcohol fuels, as well as natural gas and even dry powdered çoal.

Gas turbines face four critical technology challenges including part-load efficiency, high manufacturing cost, durability and reliability, and emissions. Temperature limitations of contemporary metallic alloys do not permit gas turbine fuel efficiency to match that of piston engines. High-temperature structural ceramic materials, required for gas turbines to achieve acceptable efficiency levels, are much more costly than conventional metallic components and have not yet been manufactured on a large scale. Ceramic components in gas turbines have not yet demonstrated long-term survivability. Finally, despite 
inherently excellent emission characteristics, oxides of nitrogen (NOx) emission levels in massproducible ceramic gas turbines are still uncertain, particularly during transient operation.

The goal of the gas turbine research and development effort is to achieve high efficiency (greater than $30 \%$ thermal efficiency at full load; $40 \%$ efficiency at $25 \%$ load), ultra-low emission, multi-fuel capable gas turbine HPU technology for application in hybrid vehicles with up to $80 \mathrm{mpg}$ fuel economy. Specific objectives are: (1) to develop and validate ceramic component production technologies suitable for automotive applications by 1998; (2) to develop and validate advanced gas turbine technology for application in hybrid test vehicles that achieve $50 \mathrm{mpg}$ and meet EPA Tier 2 requirements by 1998; and (3) to develop gas turbine technologies for application in test vehicles that achieve $80 \mathrm{mpg}$ and exceed EPA Tier 2 requirements by 2004 .

\section{PROGRAM ACTIVITIES}

In 1978, DOE established the Advanced Gas Turbine (AGT) Program, which demonstrated the operating feasibility of a ceramic gas turbine engine and the capability to operate at turbine inlet temperatures in excess of $2,200^{\circ} \mathrm{F}$. The AGT Program successfully initiated the development of a ceramic infrastructure in the U.S., established the U.S. as the world leader in the application and demonstration of ceramic technologies, and identified design technology challenges for further development.

The Advanced Turbine Technology Applications Project (ATTAP) was initiated in 1987 as a follow-on to the AGT Program, with goals to develop basic design technologies and ceramic manufacturing processes. The ATTAP demonstrated ceramic engine test-bed operation at nominal turbine inlet temperatures up to $2,375^{\circ} \mathrm{F}$; designed and demonstrated the first ceramic mixed flow turbine rotor, developed design methodologies for thermo-mechanical stress and impact resistance; enhanced ceramic properties, shape capability, and processes; and identified the need for a low-risk engine test-bed for developing operating time and reliability for gas turbine ceramics. The present GT-HPU Research and Development Program is a continuation of ATTAP and consists of two primary component technology elements, the Ceramic Turbine Engine Demonstration Project and the Hybrid Vehicle Turbine Engine Technology Support Project. The Supporting Research and Technology Project of NASA/AlliedSignal provided additional research and development.

AlliedSignal Engines is the prime contractor for the Ceramic Turbine Engine Demonstration Project, which is working to transition ceramic turbine technology from laboratory to commercial applications and validate ceramic design and manufacturing methods. Project objectives are: (1) to enhance the development of analytical design tools for ceramic components using the ceramic properties database, (2) to scale-up and improve the manufacturing processes for ceramic components, and (3) to demonstrate the reliability and durability of ceramic components through thousands of hours of testing in a modified production gas turbine engine. Design methods and evaluation techniques are being refined to improve ceramic/metal and ceramic/ceramic interfaces, to develop tools for predicting particle impact, to develop instrumentation methods, to proof test methodologies, and to accurately predict ceramic corrosion and protection. Manufacturing scale-up activities are developing control processes for consistent, highquality, high-yield, low-cost ceramic components. Engine testing is validating design and manufacturing technologies with a proven GTCP 331-200 gas turbine auxiliary power unit. Over 4,500 hours of endurance testing and over 35,000 hours of field testing of ceramic nozzles is planned.

Allison Engine Company is the prime contractor for the Hybrid Vehicle Turbine Engine Technology Support Project. The program focuses on four technology areas: structural ceramic component reliability and durability; low emission combustion concepts and control; low cost, extruded ceramic regenerator matrix and seal systems; and hot flow path thermal management and insulation. This project has been refocused to support the design and development of a ceramic gas turbine power unit for hybrid vehicles. Larger horsepower engines, such as AGT-5 and test-rig hardware, are being used to develop component and subsystem reliability and durability at engine equivalent operating conditions. These test results are readily applicable to the scaled down hybrid vehicle turbine engine designs. Current activities 
include testing ceramic regenerator disks and injection molded insulation, and cyclic durability testing of an "all ceramic" engine. Supporting work at Argonne National Laboratory (ANL) is focusing on development of advanced seal materials and fabrication techniques for regenerator cores that are critical to achieving high thermal efficiencies in advanced gas turbines.

The NASA Supporting Research and Technology Project has conducted ceramic materials characterization through extensive durability and salt corrosion testing. In addition, NASA is continuing ceramic component technology development through life prediction modeling and non-destructive evaluation (NDE) technology development.

In parallel with the primary component technology efforts within the GT-HPU Program, the Office of Advanced Automotive Technologies (OAAT) Vehicle Systems Technology Program has worked with Ford, General Motors, AlliedSignal, Allison, and Teledyne-Ryan Aeronautics to develop gas turbines for integration into test vehicles. The OAAT Automotive Materials Program is conducting critical hightemperature ceramic materials research and development that is supporting the gas turbine hybrid unit component technology efforts. In addition, OAAT maintains a close liaison with the Advanced Turbine Systems Program (Energy Efficiency and Renewable Energy Office of Industrial Technology and DOE Office of Fossil Energy). The Advanced Turbine Systems Program utilizes OAAT technologies (i.e., life prediction models, materials, components) and adapts them to larger industrial turbine engines. OAAT receives test data and additional verification of life prediction models through these large-scale industrial applications.

Currently, OAAT is preparing a new program to re-focus ongoing efforts more toward solving key problems in the development of an advanced gas turbine HPU for the $80-\mathrm{mpg}$ goal. The initial focus will continue to be on ceramic component research and development. This will be followed by turbine engine point design and development activities in subsequent years if the initial ceramic component research and development efforts are successful. Industrial partners will include one or more engine manufacturers, structural ceramic component suppliers, heat exchanger suppliers, and research laboratories.

\section{FISCAL YEAR 1996 ACCOMPLISHMENTS}

- The AlliedSignal Team has conducted 500 hours of cycle durability testing on a ceramic nozzle engine and 140 hours of cycle durability testing on a ceramic blade engine.

- The AlliedSignal Team has demonstrated manufacturing at a rate of 50 parts/month and a manufacturing capacity of 200 parts/month.

- The Allison Engine Team has demonstrated 410 hours of durability testing on an extruded magnesium aluminum silicate regenerator disk at up to $1,750^{\circ} \mathrm{F}$.

- The Allison Engine Team has conducted 10,000+ cycles on injection-molded insulation at $1,800^{\circ} \mathrm{F}$, and Corning is extruding a large diameter lithium aluminum silicate regenerator disk.

- ANL has identified and tested advanced regenerator core seal materials that meet or exceed friction and wear properties of baseline seal materials, and have the potential of being fabricated at low-cost and high-volume production rates.

- Ceramic nozzle manufacturing yields have been increased from less than $20 \%$ in 1993 to $67 \%$ in 1996 , and manufacturing costs have been reduced from $\$ 2,000+$ per part to $\$ 750$ per part.

- Capability to install (and operate under engine conditions) temperature and strain sensors on ceramic components was demonstrated. 
- Methods were developed to predict ceramic component stresses during impacts.

- Durability testing was performed on an all-ceramic gasifier power module at operating temperatures significantly above metallic engines. Total operating time had reached 142 hours by the end of fiscal year 1996, out of a total of 300 hours at test completion.

\section{ADVANCED AUTOMOTIVE PISTON ENGINES}

The overall goal of the Advanced Automotive Piston Engine Technologies Program is to work with the U.S. auto industry to reduce the petroleum consumption of light-duty vehicles through greater fuel efficiency and use of alternative fuels, and to cost-effectively achieve stringent future vehicle emissions standards. Prior to fiscal year 1996, the Program emphasis was on spark-ignited engine technology. The focus has now shifted to advanced compression-ignition, direct-injection (CIDI) engine technology.

\section{TECHNOLOGY BACKGROUND}

Representative peak efficiencies of contemporary piston engines are: $30 \%$ for port-injection, sparkignited engines; $33 \%$ for direct-injection, spark-ignited; $37 \%$ for compression-ignition, indirect injection (auto); and $42 \%$ (auto) and $46 \%$ (heavy-duty truck) for CIDI engines. Japanese manufacturers are focusing on stratified-charge lean-burn gasoline engines, where fuel economy improvements of 5\%-10\% over current gasoline engines are believed possible. Japanese manufacturers are also close to developing durable, low-cost, lean-NOx catalysts. Extensive research activities by industry (especially heavy diesel engine manufacturers) is focusing on reducing NOx and particulate matter (PM) emissions from CIDI engines through electronically controlled high-pressure fuel injection systems, exhaust gas recirculation, four-valve designs, turbo charging and intercooling, lubricating oil consumption control, oxidation catalysts, lean NOx catalysts, and particulate traps. Current automotive-sized diesel engines are nearly twice as expensive as gasoline engines per equivalent power output due to expensive, high-pressure fuel system components.

The principal limitation for advanced spark ignited engines is efficiency. Vehicle NOx emissions are too high in lean-burn mode because effective lean NOx catalysts are not available. The use of higher compression ratios for increased fuel economy increases susceptibility to engine knock. In addition, lean operation increases ignition difficulties and can cause unstable combustion and cycle-to-cycle variability.

There are several technical barriers for CIDI engine technology. NOx emissions exceed acceptable limits and NOx catalysts that operate in lean environments are not available. Other aftertreatment technologies are underdeveloped, costly, and do not have proven reliability and durability. In addition, current PM emissions are too high. Particulate traps are costly and energy intensive and other aftertreatment devices are not adequately developed. Control of fuel injection rate and timing is inadequate for optimal incylinder NOx and PM emissions control. Current CIDI engines are more costly than conventional, portinjected spark-ignition (SI) engines and suffer from operational shortcomings including poor acceleration, exhaust odor, and noisy operation.

The goal of the Advanced Automotive Piston Engine Program is to develop viable, advanced automotive piston engine technology for application in passenger cars with up to $80 \mathrm{mpg}$ fuel economy and that will meet all future emission requirements. The objectives are: (1) to develop and validate compliant NOx and PM emissions control technologies by $1998,(2)$ to improve CIDI engine efficiency with concurrent major reductions in emissions for light-duty vehicles by 2002, and (3) to advance the CIDI technology for customer-driven attributes such as cost and performance so the engines will gain rapid application and use by 2004 . 


\section{PROGRAM ACTIVITIES}

The Program was initiated in fiscal year 1993 in response to requirements of section 2022 of the Energy Policy Act of 1992. Research and development efforts have focused on light-duty piston engines for conventional and hybrid vehicles. In fiscal year 1996, the principal element of the Advanced Automotive Piston Engine Research and Development Program was the Engine Support System Technology (ESST) Program aimed at manufacturing, emission control, engine combustion control, and engine/powertrain management research and development. The ESST Program is jointly managed by a DOE-industry team and is implemented through 50\% cost shared Cooperative Research and Development Agreements (CRADAs) with the U.S. Council for Automotive Research (USCAR) Low Emission Partnership (LEP). The program is accelerating the development and commercialization of lean-burn piston engines for conventional and hybrid vehicle applications, with special emphasis on the reduction of NOx.

ANL is developing new methods to improve the practicality of laser welding; the primary challenge is to develop sensors and control systems suitable for use in mass production. ANL is investigating new NOx reducing catalysts and developing real-time exhaust gas sensors. Idaho National Engineering Laboratory (INEL) is developing a set of process and weld diagnostic tools to quantify the impact of variations in material and process on weld quality. The focus is on applying recent advances in the intelligent control of welding processes to plant floor operations in order to reduce scrap, increase product reliability, permit easier transition to more lightweight materials, and improve productivity and efficiency. INEL and Sandia National Laboratories (SNL) are applying non-destructive evaluation techniques to characterize critical properties of thermal spray coatings on cylinder bores in aluminum engine blocks. INEL is also working to develop a cost-effective, commercially viable spray forming process for the rapid production of net-shape molds, dies, and related tooling.

Pacific Northwest National Laboratory (PNNL) is developing advanced time-resolved spectrographic techniques capable of monitoring fuel-oil interactions and hydrocarbon emissions, nonthermal plasma destruction methods, and associated materials capable of reducing $\mathrm{NOx}$, as well as oxidizing hydrocarbons from an exhaust stream. PNNL is developing superplastic forming methods for the production of insulated multiwall pipe and is developing environmentally friendly manufacturing processes capable of producing advanced planar, thin film, ceramic automotive sensors. In addition, PNNL is developing holographic techniques capable of reconstructing three-dimensional spray profiles within a combustion chamber. Oak Ridge National Laboratory is characterizing the performance of prototype NOx catalysts and engineering engine systems that optimize catalyst performance.

In support of its parallel hybrid propulsion subsystem technology development effort within the Vehicle System Technology Program, Ford has teamed with FEV Engine Technology to develop high efficiency CIDI engines that will be tested in modified Ford Contour vehicles. Chrysler is developing a 3-cylinder CIDI hybrid engine with Detroit Diesel Corporation that permits parallel operation.

OAAT is currently planning an advanced automotive CIDI engine activity that will not only support hybrid propulsion technology development and achievement of the PNGV 80-mpg fuel economy objective, but will also provide an advanced engine option for much improved fuel economy in more conventional propulsion light-duty vehicles. In fiscal year 1996, this activity concentrated available resources on the primary technical barrier -- NOx emissions. Enabling research and development is being conducted at national laboratories. Figure 18 illustrates current Federal automotive CIDI technology research and development activities at DOE, EPA, the Defense Advanced Research Projects Agency (DARPA), the U.S. Army Tank-automotive and Armaments Command (TACOM), and the auto companies. 
FIGURE 18

CIDI Research Activities

DOE

$(1-14)$

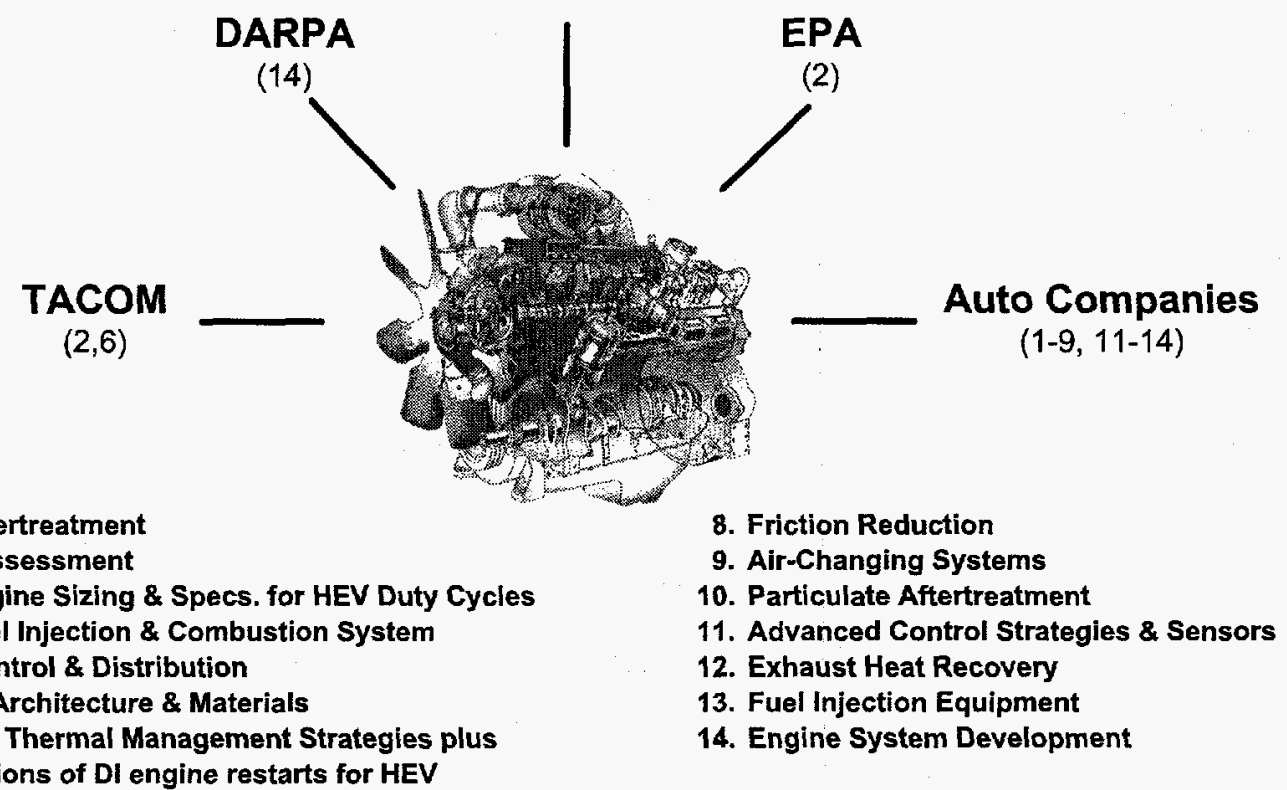

1. NOx Aftertreatment

8. Friction Reduction

2. Fuels Assessment

3. CIDI Engine Sizing \& Specs. for HEV Duty Cycles

9. Air-Changing Systems

4. CIDI Fuel Injection \& Combustion System

5. EGR Control \& Distribution

6. Engine Architecture \& Materials

7. Engines Thermal Management Strategies plus Implications of DI engine restarts for HEV

\section{FISCAL YEAR 1996 ACCOMPLISHMENTS}

- ANL successfully demonstrated a device that monitors laser welding on a transmission component manufacturing workstation at a systems integration facility. The device was implemented into the beam delivery optics of an industrial partner's manufacturing plant.

- ANL successfully demonstrated in the laboratory two real-time exhaust gas sensors (surface acoustic wave and ion mobility).

- INEL developed an advanced, real-time process diagnostic system that provides a rapid, nonintrusive means of determining the condition of welding equipment, the state of the welding process, and guidance for correcting identified problems.

- INEL demonstrated the technical feasibility of using spray forming technology for producing Kirksite (zinc-based), aluminum-based, and tool steel (D2) tooling components.

- SNL designed a CIDI single-cylinder optical access test facility for small-bore, high-speed automotive engine research. Wayne State University developed a non-optical test facility. Both will be operational in fiscal year 1997.

- Oak Ridge National Laboratory (ORNL) evaluated six prototype catalysts provided by national laboratory and industry partners, and microscopically characterized catalyst structures.

- PNNL explored the feasibility of plasma-based systems using catalytic materials to simultaneously oxidize hydrocarbons and reduce NOx for a lean-burn engine. 


\section{COMBUSTION EFFICIENCY AND EMISSIONS}

The Combustion Efficiency and Emissions Program focuses on all aspects of air-fuel mixture preparation and combustion processes relevant to conventional and advanced engine concepts. The Program supports research by technical teams of engine combustion experts from the DOE national laboratories, U.S. universities, and domestic engine companies.

\section{TECHNOLOGY BACKGROUND}

The importance of understanding in-cylinder processes to improving engine efficiency and reducing emissions (at the source) is recognized by the worldwide auto industry. This has led to considerable international efforts to develop and make available advanced diagnostic tools and improved combustion models to engine designers. All major European and Japanese automobile manufacturers use laser diagnostics and computational fluid dynamics (CFD) in their engine development processes. Their use includes basic research on fundamental processes, production hardware evaluation, and design improvement. The techniques include: Laser Doppler Velocimetry, Phase Doppler Anemometry, and Laser-illuminated Imaging. These three diagnostics, and CFD, are the most widely used because they are commercially available. The use of planar laser-induced fluorescence is growing rapidly, because it is well-suited to study the in-cylinder fuel-air distribution of stratified-charge SI engines. Use of laserinduced incandescence and laser Mie scattering is beginning to increase in investigations of diesel combustion and soot formation.

Principal technical areas being addressed by combustion researchers include NOx and particulate emissions, modeling, and port fuel injection. Emission control is an ongoing problem in conventional, lean-burn, and direct-injection engines. Emission control is more difficult for lean-burn and directinjection engines in part due to the lack of viable lean NOx catalysts. Modeling codes are not available that adequately describe and predict the mixture formation and combustion processes. The fuel injection process in current port fuel injected engines is not sufficiently understood to optimize engine performance when cold starting and during speed and load transients. In addition, unburned fuel can survive the combustion process. Determining how this fuel survives and is exhausted would provide designers information to minimize hydrocarbon emissions and improve efficiency.

The goal of the Combustion Efficiency and Emissions Program is to support the needs of the automobile industry in developing improved conventional and advanced automobile piston engines with enhanced efficiency, emissions, and alternative fuel capabilities. Specific objectives are: (1) to better understand the mechanisms that govern the quality of fuel-air mixing for both port fuel injected and direct injected SI and compression ignition engines by 1998 , (2) to better characterize fuel injector sprays and their impact on engine performance by 1998 , (3) to better understand combustion and subsequent processes that lead to unburned fuel being exhausted by 1998, and (4) to develop more sophisticated diagnostic tools that will lead to a better understanding of the processes that occur in-cylinder that govern efficiency and emissions by 1999.

\section{PROGRAM ACTIVITIES}

Since the early 1980s, DOE has supported engine combustion research at national laboratories and universities through the former Energy Conversion and Utilization Technologies Program. In fiscal year 1994, selected combustion related projects were transferred to the Office of Transportation Technologies from the Office of Industrial Technologies. SNL is the technical manager for the Combustion Efficiency and Emissions Program and has organized other national laboratories, universities, and the auto industry to address two technical tasks, (1) fuel combustion system optimization and (2) cylinder design for reduced emissions. CRADAs are used to formalize partnerships between DOE national laboratories and the domestic automakers. Competitive procurement is the mechanism to fund university research, with 
topics of interest developed in conjunction with the domestic engine companies. Teams of research engineers and scientists meet regularly each year to discuss recent results and current needs and interests.

Significant efforts are underway to improve the understanding of in-cylinder processes involved as a means to reduce engine-out emissions and enhance efficiency. The Program effort focuses on characterizing the fueling process in port fuel-injected engines to optimize injection parameters and fueling schedules. Optical diagnostic tools for visualizing in-cylinder fluid flows and combustion chemistry have matured, and are now beginning to be applied in optically accessible engines to understand critical control processes. Figure 19 illustrates laser-induced fluorescence images of liquid gasoline films in the combustion chamber of a production, port fuel-injected engine. These results compare strategies where the intake valves are either open or closed during the fuel-injection process. This innovative technique reveals the evolution of liquid film formation during the cold-start of an SI engine, and is being used to investigate new technologies for the reduction of unburned hydrocarbon and soot emissions. In addition, computational fluid dynamics codes and complex chemical kinetics models are being combined and programmed onto massively-parallel, super computer systems. This will allow more accurate predictions of the important in-cylinder phenomena that control the fuel conversion efficiency and pollutant formation, leading to better engine design.

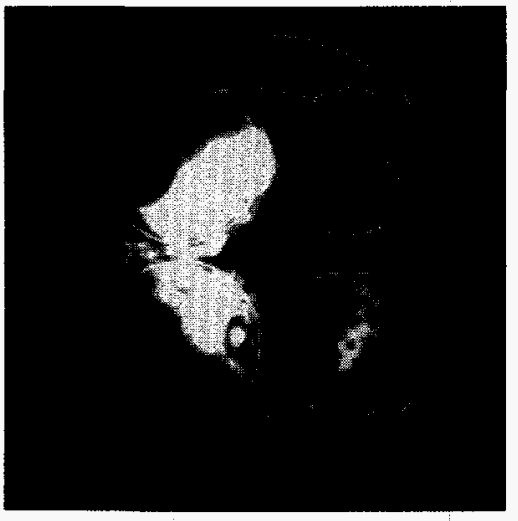

OPEN-VALVE INJECTION

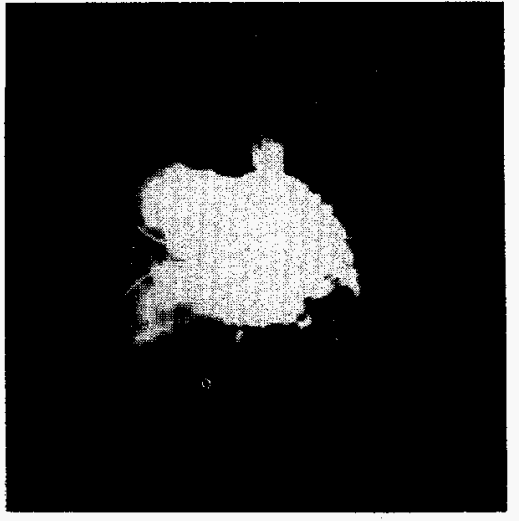

CLOSED-VALVE INJECTION

\section{FISCAL YEAR 1996 ACCOMPLISHMENTS}

- SNL completed development and demonstration of a diagnostic technique and model to track the evolution of unburned crevice hydrocarbons in a single-cylinder research engine.

- SNL completed engine test to evaluate the role of turbulence on the fuel-injection process.

- SNL developed improved computer models of in-cylinder processes that apply to CIDI and SI engines.

\subsection{ELECTRIC VEHICLE BATTERIES}

\section{INTRODUCTION}

The goal of the Electric Vehicle Battery Program is to support the research and development of advanced rechargeable battery technologies that will accelerate the commercial introduction of electric vehicles and support a sustainable market for these vehicles. Market acceptance of electric vehicles will depend on their ability to provide the range, durability, performance, and other amenities that consumers have come to expect from conventional vehicles -- at a competitive cost. Currently, the major limiting factors for electric vehicle technology are high cost, limited operating range, and lengthy. refueling time (recharging). The battery is the main component affecting these factors. 
The successful commercialization of electric vehicles will directly reduce our Nation's growing dependence on petroleum fuels for transportation, since less than $2 \%$ of our electricity is generated from petroleum. It will also reduce emissions and facilitate the transition to renewable energy sources while enhancing the competitiveness of U.S. automobile and battery manufacturers. Recognizing the enormous potential market for advanced energy storage devices in vehicles and other consumer/industrial applications, organizations worldwide are investing heavily in battery research and development. International competition is intense and growing, and substantial progress is being reported.

The Electric Vehicle Battery Program is working closely with the automobile industry, battery developers and manufacturers, electric utilities, and national laboratories (see Table 9) to identify and advance the most promising technology alternatives to a point from which industry can proceed on its own toward commercialization. The Program is consistent with the requirements of Section 2025: Electric Motor Vehicles and Associated Equipment R\&D of the Energy Policy Act of 1992. The Program also directly supports the automobile industry in meeting upcoming state and industry agreements or mandates for zero-emission vehicles (ZEVs). The State of California requires that $10 \%$ of automobiles sold in the state in 2003 be ZEVs (i.e., electric vehicles). The major automakers have also agreed to introduce a limited number of electric vehicles into the state before 2003 for field testing and demonstration purposes.

The Electric Vehicle Battery Program consists of three major elements: (a) Cooperative research and development with the United States Advanced Battery Consortium (USABC), (b) Exploratory Technology Research, and (c) Electric Vehicle Readiness activities. These program elements are discussed in the following sections.

\section{UNITED STATES ADVANCED BATTERY CONSORTIUM}

\section{TECHNOLOGY BACKGROUND}

DOE has supported research in electric vehicle batteries for nearly two decades. In 1991, recognizing that the development of several advanced battery alternatives is beyond the resource capabilities of any individual organization, DOE began working cooperatively with the domestic automobile, electric utility, and battery industries through the USABC. This cooperative effort has become the focus of DOE's Electric Vehicle Battery Program, which is working toward the following principal technical goals:

- By 1998, develop mid-term advanced electric vehicle battery technologies with the key characteristics shown in Table 10.

- By 2000-2001, complete development of technology for long-term advanced electric vehicle batteries with the key characteristics shown in Table 10.

The mid-term targets are based on the minimum vehicle characteristics required to achieve customer satisfaction in the marketplace; they represent a compromise between performance, cost, and availability in the earliest possible timeframe. When attained, the long-term targets will provide an electric vehicle range and performance comparable to today's gasoline-powered vehicles. These technical targets reflect the critical importance of four major battery parameters: energy, power, life, and cost. Energy and power are reflected in vehicle range and acceleration performance, both of great importance to customers. Users have certain expectations about a vehicle's service and economic life. Current leadacid batteries are replaced every 2 to 3 years. Advanced batteries are projected to have longer lives. To date, however, the lack of adequate laboratory and field test experience with advanced batteries gives a limited basis for establishing life expectations and suitable warrantees. Finally, the cost of advanced batteries is an important component of the electric vehicle cost equation and of great concern to both manufacturers and customers. However, production experience is currently very limited. Pilot production and field testing are required to validate these technologies for life and cost, in addition to 
TABLE 9

Electric Vehicle Battery Research and Development

Fiscal Year 1996 Program Participants

\begin{tabular}{|c|c|c|}
\hline Participant Organization & $\begin{array}{l}\text { Funding } \\
\text { Mechanism }\end{array}$ & $\begin{array}{l}\text { Participant } \\
\text { Cost Share }(\%)\end{array}$ \\
\hline \multicolumn{3}{|l|}{ U.S. Advanced Battery Consortium } \\
\hline Ovonic Battery Company & Contract & $50 *$ \\
\hline SAFT America & Contract & $50^{*}$ \\
\hline Yardney Technical Products & Contract & $50^{*}$ \\
\hline W.R. Grace & Contract & $50^{*}$ \\
\hline $3 \mathrm{M}$ & Contract & $50^{*}$ \\
\hline Duracell/Varta & Contract & $50^{*}$ \\
\hline $\begin{array}{l}\text { Argonne National Laboratory } \\
\text { Idaho National Engineering Laboratory } \\
\text { Sandia National Laboratories }\end{array}$ & CRADA** & 0 \\
\hline \multicolumn{3}{|l|}{ Exploratory Technology Research } \\
\hline Covalent Associates & Contract & 0 \\
\hline PolyPlus Company & Contract & 0 \\
\hline SRI International & Contract & 0 \\
\hline Case Western Reserve University & Grant & 0 \\
\hline Northwestern University & Grant & 0 \\
\hline SUNY Binghamton & Grant & 0 \\
\hline Southern University & Grant & 0 \\
\hline University of Michigan & Grant & 0 \\
\hline University of South Carolina & Grant & 0 \\
\hline $\begin{array}{l}\text { Lawrence Berkeley National Laboratory } \\
\text { Los Alamos National Laboratory } \\
\text { Lawrence Livermore National Laboratory } \\
\text { Oak Ridge National Laboratory } \\
\text { Brookhaven National Laboratory }\end{array}$ & $\begin{array}{l}\text { Field Work } \\
\text { Proposal }\end{array}$ & 0 \\
\hline \multicolumn{3}{|l|}{ Electric Vehicle Readiness } \\
\hline National Renewable Energy Laboratory & Field Work Proposal & 0 \\
\hline
\end{tabular}

* Represents the combined cost share of the contractor participant and the USABC partners.

** $\quad$ CRADA $=$ Cooperative Research and Development Agreement 
TABLE 10

Advanced Battery Technology for Electric Vehicles: Key Targets*

Mid-Term (1998) and Long-Term (2000-2001)

\begin{tabular}{|l|c|c|c|c|}
\hline \multicolumn{1}{|c|}{ Key Characteristics } & Units & Mid-Term Battery & Long-Term Battery \\
\hline Power-to-Weight Ratio & W/kg & $150-200$ & 300 \\
\hline Energy-to-Weight Ratio & Wh/kg & $80-100$ & 150 \\
\hline Cycle Life & Cycles & 600 & 1000 \\
\hline Calendar Life & Years & 5 & 10 \\
\hline Production Cost & $\$ / \mathrm{kWh}$ & $<250$ & $<150$ \\
\hline
\end{tabular}

* Partial list of key targets

ongoing research and development aimed at cost-reduction. The long-term battery technologies (such as lithium/polymer) are in even earlier stages of development. Serious technical challenges have to be addressed over the next few years to validate these technologies for electric vehicle applications and bring them to the pilot production stage.

\section{PROGRAM ACTIVITIES}

Since 1991, the Phase I effort of the USABC Program has focused on identifying and developing the most promising mid-term technologies and demonstrating the promising long-term technologies. Research and development participants include battery developers (e.g., SAFT America, Yardney, Ovonic, 3M, Duracell/Varta) and their suppliers, as well as several national laboratories through Cooperative Research and Development Agreements (CRADAs). The Phase I effort was essentially completed in fiscal year 1996 and has made substantial progress toward developing nickel-metal hydride and lithium-ion technologies for the mid-term, and lithium/polymer for the long-term. The consortium approach of jointly conducting high-risk, high-cost battery research and development has allowed the leveraging of both technical and financial resources, and enabled more to be accomplished in less time than any one organization could have achieved working alone. The successes achieved with advanced battery technologies are reflected in the next generation of electric vehicles announced by U.S. and Japanese manufacturers.

\section{USABC PHASE II PROGRAM}

Despite the progress achieved so far, the advanced batteries do not yet meet the anticipated customer requirements for energy, power, life, and cost. The DOE-USABC Program intends to build upon the successes achieved and lessons learned during the Phase I effort to accelerate the development of advanced battery technologies to the stage where the private sector can proceed on its own with commercialization activities. Several specific steps will be required over the next few years. The specific battery technologies and their manufacturing processes need to be developed further to bring a reliable cost-effective product to market. The advanced batteries need to be produced in quantity on a pilot scale to validate production processes in terms of product quality and process economics. The performance, reliability, safety, and life of these batteries must be evaluated as integrated components in electric vehicles under representative driving conditions.

In August 1996, Chrysler, Ford, General Motors, the Electric Power Research Institute (EPRI), participating utilities, and the DOE signed a second cooperative agreement for the Phase II effort to extend the USABC Program until 2000. The primary objectives of the Phase II effort are to: 
- Conduct more extensive safety, life (durability), and verification tests on mid-term batteries.

- Support cost reduction research for mid-term technologies.

- Take the most promising long-term technologies (lithium/polymer) through pilot feasibility, i.e., advance them to a similar state-of-development as mid-term batteries at the end of Phase I.

The USABC will continue to review emerging technologies and new proposals from battery developers as potentially viable candidates for inclusion in its research and development portfolio. Examples of such emerging technologies and new proposals include the lithium-ion technology under development by Duracell/Varta and the ambient temperature, lithium/polymer technology developed by Ultra Life Batteries, Inc., which could meet the mid-term criteria.

\section{FISCAL YEAR 1996 ACCOMPLISHMENTS}

- Established nickel-metal hydride battery technology as the prime mid-term candidate for electric vehicles based on performance and life testing. Development work is continuing on cost reduction and improving battery life.

- SAFT America and Ovonic Battery Company delivered nickel-metal hydride battery packs to power prototype electric vehicles.

- Based on technical progress achieved in a development program, General Motors and Ovonic Battery Company announced a joint venture to pursue early, low volume, pilot production of nickel-metal hydride batteries for electric vehicles.

- Based on performance and life testing results, lithium/polymer battery technology was established as the most promising long-term battery technology and significant progress was achieved in its development.

\section{EXPLORATORY TECHNOLOGY RESEARCH}

\section{TECHNOLOGY BACKGROUND}

Advanced rechargeable battery systems offer the potential for high performance and low life-cycle costs, and remain the key to achieving fully competitive electric vehicles. To successfully establish and advance the technology base for electric vehicle batteries, there is a continuing need to:

- Identify and investigate new electrochemical couples that can lead to dramatically improved advanced batteries for electric vehicles, even beyond what is now under development by the USABC. A good example is the lithium/sulfur battery with its environmentally benign components and high theoretical specific energy ( $2600 \mathrm{Wh} / \mathrm{kg}$ versus $220 \mathrm{Wh} / \mathrm{kg}$ for nickel-metal hydride).

- Improve the performance of battery components and materials to enhance the commercialization prospects of the battery technologies (nickel-metal hydride and lithium-based systems) currently being developed by the USABC.

- Develop new and improved methods (including advanced experimental and modeling tools) to characterize and monitor the performance of battery components, and establish engineering principles that can be used to predict the performance of batteries during operation.

To address these needs, DOE supports an Exploratory Technology Research Program that is managed by Lawrence Berkeley National Laboratory (LBNL) with the active involvement of other national 
laboratories, universities, and industrial organizations. The Program provides a bridge between the fundamental electrochemical research supported by the DOE's Office of Basic Energy Sciences and the electrochemical device development carried out by the USABC. The Exploratory Technology Research Program is currently focused on three areas: new battery systems, improved materials and components for USABC technologies, and cross-cutting diagnostic studies. These three elements of the Program are discussed in the following section.

\section{PROGRAM ACTIVITIES}

\section{New Battery Systems}

The lithium/sulfur battery technology under development at LBNL is showing promising results with potential suitability for electric vehicle application. Researchers at Oak Ridge National Laboratory (ORNL) are exploring the use of a thin-film technology to produce all-solid-state lithium/lithium manganese oxide cells. This technology offers the possibility of developing thin compact batteries that do not require a liquid electrolyte phase. Several battery technologies using sodium electrodes were also investigated in fiscal year 1996. SRI International evaluated the performance of a new polysulfide electrode in a battery. The Georgia Institute of Technology explored the feasibility of a molten-salt electrolyte that operates in a battery at room temperature. This project was conducted in collaboration with EPRI.

\section{Improved Materials and Components for USABC Technologies}

A collaborative effort between LBNL, Lawrence Livermore National Laboratory, and Superior Graphite Company has led to the identification of a carbon material that shows promise for lithium-ion batteries. Research at Northwestern University, Case Western Reserve University, and the University of Dayton is focusing on synthesizing better polymer electrolytes (in the form of thin plastic-like films) for lithium/polymer batteries. Other projects are exploring innovative electrode materials. The State University of New York at Binghamton is developing a synthesis process that can be carried out at low temperature to produce a low-cost lithium manganese oxide for the positive electrode. To obtain stable performance in lithium batteries, Covalent Associates has developed a processing approach that yields lithium manganese oxide incorporating an additive (chromium). To improve the life of the lithium negative electrode, $\mathrm{LBNL}$ is exploring the use of a thin film $\left(\mathrm{Li}_{3} \mathrm{~N}\right)$ located between the reactive lithium and the polymer electrolyte.

The Exploratory Technology Research Program is supporting materials research to improve the performance and life of nickel-metal hydride batteries. The LBNL has demonstrated that the addition of cobalt to the nickel electrode improves its performance. The University of Michigan recently initiated research to improve the performance of the nickel electrode by examining a different structure based on nickel fibers. To improve the performance of the metal hydride electrode, researchers at the University of South Carolina coated the electrode with copper and observed an improvement over electrodes without copper coating.

The Exploratory Technology Research Program is also supporting the development of electrochemical capacitors for use in hybrid electric vehicles. The University of Wisconsin is investigating the use of nickel oxide/nickel electrodes in capacitors. Tests were performed with various electrolytes. The results indicate that a capacitor using an aqueous alkaline solution of lithium hydroxide has double the performance of a capacitor that uses potassium hydroxide electrolyte. SAFT America is taking another approach and evaluating carbon electrode materials combined with a nonaqueous electrolyte. Capacitors will be delivered by the research contractors to Idaho National Engineering Laboratory (INEL) for testing. 


\section{Diagnostic Studies}

Successful development of improved battery materials and components requires a clear understanding of their properties and behavior in a battery operating environment. The Exploratory Technology Research Program supports a significant effort to develop sophisticated new experimental techniques that can be applied to examining the properties of new materials and to monitor their behavior in batteries. DOE user facilities, such as the National Synchrotron Light Source and the Stanford Linear Accelerator Center, provide powerful tools to probe the structure and composition of battery materials by X-ray absorption spectroscopy (XAS). Brookhaven National Laboratory has applied this technique to study the properties of lithium-based battery electrode materials $\left(\mathrm{Li}_{\mathrm{x}} \mathrm{NiO}_{2}, \mathrm{Li}_{\mathrm{x}} \mathrm{CoO}_{2}, \mathrm{Li}_{\mathrm{x}} \mathrm{Mn}_{2} \mathrm{O}_{4}\right)$. The experimental investigations indicate that the structure of these electrode materials undergoes changes during charge/discharge cycling.

Modeling tools, which involve the use of mathematical concepts and electrochemical engineering principles, provide valuable predictive capabilities to understand the performance of battery components and complete systems during operation. The Exploratory Technology Research Program supports the development of sophisticated mathematical models as well as necessary data to validate the models. These efforts have yielded valuable insights that directly benefit battery development activities. For example, the mathematical modeling results at LBNL indicate that, during normal operation, the temperature of a lithium-ion battery is unlikely to reach the onset temperature for thermal runaway. However, if a battery is continuously cycled under high-rate charge and discharge, significant heat accumulation may occur. This information is useful for designing the thermal management system and to ensure safe operation of the battery. Modeling studies at Northwestern University have provided information to guide the development of improved polymer electrolytes for lithium/polymer batteries. Transport properties such as transference numbers and diffusion coefficients are being measured at LBNL to use in the models.

\section{ELECTRIC VEHICLE READINESS}

In fiscal year 1996, DOE continued to advance the readiness of electric vehicles and associated infrastructure by working closely with the automobile and electric utility companies, standards setting organizations, battery developers, and other interested parties. These activities are summarized below.

\section{ELECTRIC VEHICLE INFRASTRUCTURE WORKING COUNCIL}

The Electric Vehicle Infrastructure Working Council (IWC), sponsored by EPRI, is a collaborative effort of automobile manufacturers, utilities, government agencies, industry associations, component manufacturers, and standards organizations. The IWC works to enhance consumer safety, ensure electric vehicle compatibility, and reduce costs for product manufacturers, utility energy suppliers, and vehicle buyers. In fiscal year 1996, the National Renewable Energy Laboratory (NREL) played an active role in several IWC committees, including the Health and Safety Committee; the Building Codes Subcommittee, which formulates building codes to ensure electric vehicle safety; and the Personnel Protection Subcommittee, which identifies parameters for personnel safety.

During fiscal year 1996, the IWC Health and Safety Committee accomplished several major tasks. First, it developed electric vehicle charging code language for the National Electrical Code (NEC). The NEC provisions are adopted worldwide and provide guidelines for electrical safety on electric vehicle charging equipment and systems. Second, the Committee developed amendments to the U.S. model building codes to facilitate electric vehicle charging in garages. The model codes determine building practices nationwide. Third, the Committee conducted an Underwriters Laboratories, Inc. study on the performance requirements for personnel protection equipment. The Committee developed parameters for personnel safety when charging or servicing electric vehicles. 


\section{AD HOC ADVANCED BATTERY READINESS WORKING GROUP}

The DOE Ad Hoc Advanced Battery Readiness Working Group is a government-industry cooperative effort to identify environmental, health, and safety issues associated with the shipment, in-vehicle use, and recycling/disposal of advanced batteries for electric vehicles. The Working Group is a forum in which regulatory requirements are identified and action plans recommended. The Working Group consists primarily of representatives from battery developers, domestic automakers, Federal agencies, and national laboratories.

The Working Group is composed of three sub-working groups that review regulatory issues of shipping, in-vehicle safety, and recycling. The Shipping Sub-working Group provides organizational and technical support to facilitate the collection of information for regulatory applications. The In-vehicle Safety Subworking Group reviews and discusses the implications of hazards associated with batteries in electric vehicle propulsion, and reviews and comments on Federal Motor Vehicle Safety Standard proposed rules. The Recycling/Disposal Sub-working Group assesses the technical, regulatory, and institutional issues involved in recycling advanced batteries and the feasibility of recycling as an alternative to disposal.

The fiscal year 1996 Working Group meeting was held in Washington, DC on March 21-22, 1996. The General Session focused on infrastructure planning and electric vehicle regulatory developments. General Session presentations covered international activities, safety issues, California activities, infrastructure issues, and fast charging.

Representatives of Valence Technology, Inc. and Duracell presented test results of the reactivity of lithiated carbons with water to the Shipping Sub-working Group. Reaction rates were less than that of lithium metal, but the rate of hydrogen production exceeded the Department of Transportation's criteria for "Dangerous When Wet" materials. The Sub-working Group agreed to develop safety performance tests for lithium-ion and lithium/polymer batteries.

The In-Vehicle Safety Sub-working Group conducted a review of the Safety Issues Opinion Survey report. This survey addressed 39 potential safety issues of concern. A total of 38 responses were received from the automotive industry, battery manufacturers, electric utilities, government agencies, and government laboratories. The Sub-working Group presented issues identified in the survey to the Society of Automotive Engineers (SAE) and DOE. It presented perceived needs for standards, guidelines, and test methods to the SAE Electric Vehicle Battery Safety Issues Task Force. Safety concerns and recommendations for addressing these concerns were provided to DOE.

The Recycling Sub-working Group received an update from the U.S. Environmental Protection Agency (EPA) on its solid waste program, and from the California Air Resources Board (CARB) on its activities. The Sub-working Group reviewed the recycling progress chart and heard presentations on lithium-ion and zinc-air batteries. The Sub-working Group will continue its outreach activities by maintaining contacts with related International Energy Agency activities, CARB, EPA, and recycling groups, as needed.

\section{ENVIRONMENTAL, HEALTH, AND SAFETY ASSESSMENTS}

DOE has provided ongoing support for several years to NREL for conducting environmental, health, and safety (EH\&S) assessments of advanced energy storage systems for electric vehicles. In fiscal year 1996, NREL conducted an assessment of electrochemical capacitors, producing a report entitled Current Status of Environmental, Health, and Safety Issues of Electrochemical Capacitors for Advanced Vehicle Applications. This assessment identified important EH\&S issues pertaining to electrochemical capacitor systems, particularly those issues requiring further analysis. 


\subsection{FUEL CELL SYSTEMS}

\section{INTRODUCTION}

Fuel cells have emerged in the last decade as a possible replacement for the internal combustion engine in vehicles because they are very efficient, have extremely low or zero emissions, and are fuel flexible. Development advances have indicated potential to meet the necessary automotive requirements. Sections 2025 (j) and 2026 of the Energy Policy Act of 1992, Public Law 102-486 (EPACT), call for a comprehensive program of research, development, and demonstration of fuel cells and related systems for transportation applications.

DOE coordinates with other agencies to ensure that provisions of EPACT are met. The fuel cell program is conducted in support of the Partnership for a New Generation of Vehicles (PNGV). In cooperation with the U.S. Council of Automotive Research (USCAR), DOE formed the Fuel Cell Alliance to provide a mechanism for obtaining industry consensus and recommendations for program direction. The Alliance facilitates supplier-customer relationships to ensure that federally-sponsored laboratory research and development is transitioned to industry suppliers, and that industry supplier development (costshared) is made available to the domestic automakers.

A fuel cell is a device that converts the chemical energy of a fuel into electricity without combustion as an intermediate step. Fuel cells are similar to batteries in that both produce a direct current by means of an electrochemical process. Unlike batteries, however, fuel cells can operate continuously as long as they are supplied with fuel. Like batteries, fuel cells are combined into groups, called stacks, to achieve a useful voltage and power output.

The proton-exchange-membrane (PEM) fuel cell is the focus of current development efforts to replace the internal combustion engine in transportation applications because it has higher power density and can start up more quickly than other fuel cell types. The Office of Transportation Technologies (OTT) is focusing PEM fuel cell technology development efforts on light-duty vehicles because this market segment offers the greatest potential energy and environmental benefits. Methanol, ethanol, hydrogen, natural gas, and gasoline are being evaluated for fueling these vehicles. PEM fuel cells have achieved impressive performance gains in the last decade, to the point where in-vehicle demonstrations are proceeding in the United States, Europe, and Japan.

The program promotes energy diversity through a fuel-flexible fuel strategy in the near-term, which includes conventional fuels with existing fuel supply infrastructures, and a transition to renewable energy sources in the long-term. Alternative fuels (methanol, ethanol, hydrogen, natural gas) derived from a range of energy sources can be used in a fuel cell vehicle. The potential use of hydrogen or ethanol produced from renewable energy sources affords an opportunity for a gradual transition to alternative fuels as the supply and distribution infrastructure is made available. The DOE Fuels Development Program supports development of the infrastructure needed for production and distribution of hydrogen, methanol, and ethanol.

Two basic strategies being considered for providing the fuel cell stack with a supply of hydrogen at required purity levels are on-board fuel processing and on-board storage of hydrogen.

For on-board fuel processing, a petroleum-based or alternative fuel stored on the vehicle undergoes reforming and processing to produce the required hydrogen. On-board reformation adds complexity to the system; however, it has the advantage of using a fuel for which the distribution infrastructure is already developed.

On-board hydrogen storage and off-board reformer development are thrusts of DOE's Hydrogen Program. The fuel cell vehicle (FCV) development activities are being coordinated with DOE Hydrogen 
Program activities to expand hydrogen production capability under the Matsunaga Hydrogen Act (Public Law 101-556). Because the existing hydrogen market is very small today, production and distribution infrastructures must be developed.

The OTT Fuel Cells in Transportation Program includes technology research and development for fuel cell systems, fuel processors and storage, and components. These program elements are closely coordinated to facilitate the integration of advanced materials and components, and fuel processing and storage technology, into the fuel cell power system. The current participants in the program are listed in Table 11. Program activities and accomplishments during fiscal year 1996 are described in the following sections.

TABLE 11

Fuel Cell Systems Research and Development

Fiscal Year 1996 Program Participants

\begin{tabular}{|c|c|c|}
\hline Prime Contractors/laboratories. & Mechansm & Costicipant \\
\hline \multicolumn{3}{|l|}{ Systems Development } \\
\hline General Motors Corporation & Contract & 20 \\
\hline Ford Motor Company & Contract & 20 \\
\hline Pentastar Electronics, Inc. (a Chrysler company) & Contract & 20 \\
\hline \multicolumn{3}{|c|}{ Fuel Processor and Storage Research and Development } \\
\hline Arthur D. Little & Contract & 20 \\
\hline Los Alamos National Laboratory & Field Work Proposal & 0 \\
\hline Argonne National Laboratory & Field Work Proposal & 0 \\
\hline \multicolumn{3}{|l|}{ Component Research and Development } \\
\hline Energy Partners & Contract & 15 \\
\hline Texas A\&M University & Contract & 15 \\
\hline International Fuel Cells & Contract & 30 \\
\hline AlliedSignal & Contract & 15 \\
\hline Arthur D. Little & Contract & 15 \\
\hline Vairex & Contract & 15 \\
\hline Argonne National Laboratory & Field Work Proposal & 0 \\
\hline Los Alamos National Laboratory & Field Work Proposal & 0 \\
\hline Lawrence Berkeley Laboratory & Field Work Proposal & 0 \\
\hline Brookhaven National Laboratory & Field Work Proposal & 0 \\
\hline
\end{tabular}

\section{SYSTEMS TECHNOLOGY DEVELOPMENT}

\section{TECHNOLOGY BACKGROUND}

Past research and development has emphasized increasing the power density of the fuel cell stack and developing fuel flexible-fuel processors, with much less emphasis on integrating these systems. Recognizing the interdependency of the system components, increased attention is being given to 
technologies to optimize the complete power system. System-level contracts are currently ongoing with General Motors, Ford, and Chrysler/Pentastar. These three projects are focused on the development of automotive-scale PEM fuel cell systems $(30-50 \mathrm{~kW})$. They represent the first effort by each of the three domestic automakers and fuel cell developers to integrate all of the individual fuel cell components into complete automotive-scale laboratory prototype systems. These contracts are addressing the difficult technical issues of vehicle integration, fuel cell packaging, and fueling issues. Under each system development effort, substantial gains have been made in increasing performance and in decreasing size and weight of PEM fuel cells.

\section{PROGRAM ACTIVITIES}

General Motors completed the second year of a 30-month contract to develop a 50-kW methanol-fueled PEM fuel cell system. The research and development team includes the General Motors Research and Development Center as the prime contractor and several participating General Motors divisions of Delphi Automotive Systems, namely Delphi Energy and Engine Management Systems, Delphi Harrison, Delphi Packard, and Delco Electronics. Key subcontractors include DuPont, Dow Chemical, Ballard Power Systems, and Los Alamos National Laboratory (LANL).

During fiscal year 1996, General Motors made significant progress in fuel processing technology with the development of a $30-\mathrm{kW}$ catalytic combustor that offers significant advantages over flame combustor technology. This lower-cost, low-temperature combustor simplifies the fuel system and reduces software control requirements. The combustor was integrated into a complete $30-\mathrm{kW}$ methanol fuel processor and is under test to demonstrate a power density greater than $500 \mathrm{~W} / \mathrm{L}$. Under subcontract to General Motors, Ballard Power Systems assembled two 30-kW PEM fuel cell stacks. Testing at the Delphi Engineering Center demonstrated a stack power density of $300 \mathrm{~W} / \mathrm{L}$.

In fiscal year 1996, Ford Motor Company completed Phase I of a 30-month contract to develop a hydrogen-powered PEM fuel cell power system for light-duty vehicles (see Figure 20). Energy Partners (West Palm Beach, FL); International Fuel Cells (South Windsor, CT); Mechanical Technology, Inc. (Latham, NY); H Power Corp. (Belleville, NJ); and Tecogen Division of Thermo Power Corporation (Waltham, MA) developed and tested PEM fuel cells of up to $11 \mathrm{~kW}$ output under subcontract to Ford (see Figure 21). Ford's Phase I stack performance targets of $10 \mathrm{~kW}$ gross power, $0.28 \mathrm{~kW} / \mathrm{kg}$ specific power, and $0.25 \mathrm{mg} \mathrm{Pt} / \mathrm{cm}^{2}$ catalyst loading were met. Based on the results of testing, Ford selected International Fuel Cells and Mechanical Technology, Inc. to proceed into Phase II for an integrated fuel cell power system with a $50 \mathrm{~kW}$ PEM stack.

Also under the Ford program in fiscal year 1996, a team of Lawrence Livermore National Laboratory; EDO Fiber Science (Salt Lake City, UT); and Aero Tec Laboratories, Inc. (Ramsey, NJ) successfully demonstrated an advanced bladder-lined composite hydrogen storage tank suitable for automotive applications. The tank can store hydrogen at 5,000 psi, advancing the state-of-the-art for lightweight compressed gas storage. In Phase II, the safety aspects of on-vehicle hydrogen storage in enclosed garages will be evaluated.

Chrysler/Pentastar completed the second year of a 30-month contract to develop a PEM fuel cell propulsion system using a design-to-cost approach. The Pentastar (Huntsville, AL) team includes Chrysler Liberty (Madison Heights, MI) and an AlliedSignal team led by AlliedSignal Aerospace Systems and Equipment (Torrance, CA) that also includes AlliedSignal Automotive (Southfield, MI) and AlliedSignal Research and Technology (Morristown, NJ). During fiscal year 1996, a Prototype II baseline PEM fuel cell stack design with a specific power and power density of $0.62 \mathrm{~kW} / \mathrm{kg}$ and $0.62 \mathrm{~kW} / \mathrm{L}$, respectively, was developed by AlliedSignal. AlliedSignal also completed initial development of lightweight carbon-coated metal and conductive plastic bipolar plates. Based on AlliedSignal's design-to-cost analysis for one million vehicles per year, this reduced the projected cost for these PEM fuel cells by an order of magnitude to $\$ 73 / \mathrm{kW}$ and $\$ 50 / \mathrm{kW}$, respectively (see Figure 22 ). Pentastar also completed the final draft of a conceptual design report for a Chrysler LH sedan with a 
FIGURE 20

\section{Ford's Conceptual Design for a Ground Up Zero-Emission Fuel Cell Vehicle}

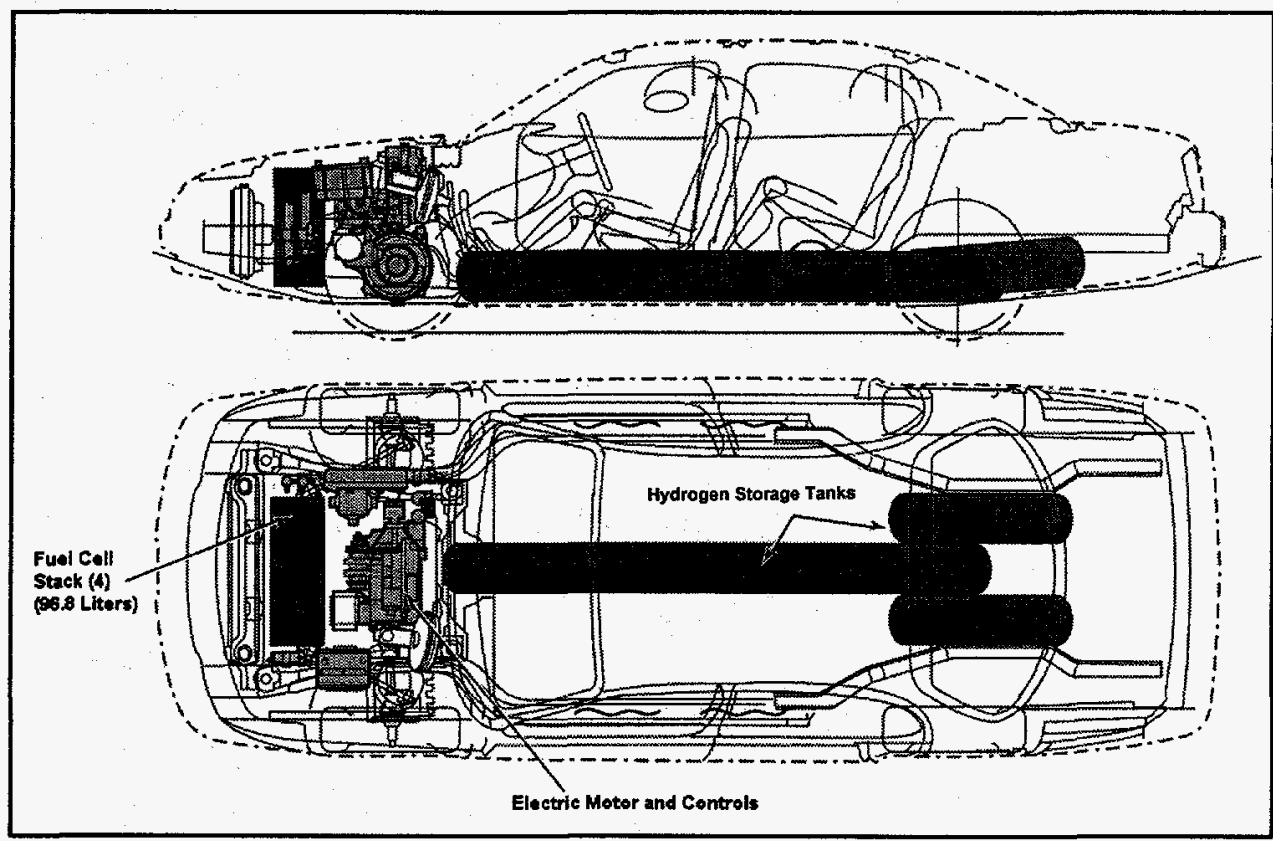

50-kW (gross) PEM fuel cell stack as the primary power source and a battery-powered load-leveling unit for acceleration and regenerative braking.

\section{FISCAL YEAR 1996 ACCOMPLISHMENTS}

- General Motors developed and demonstrated a uniform, continuous process for applying electrocatalysts to membranes, using a 0.0035 -inch thick Nafion ${ }^{\mathrm{TM}}$ composite membrane with improved performance and handling characteristics developed by DuPont for General Motors.

- General Motors demonstrated stable performance of metallic bipolar plates with advanced corrosionresistant coatings that are expected to substantially increase the specific power and power density of its PEM fuel cell.

- General Motors identified a water/gas shift catalyst with more than twice the activity of the best previously known shift catalysts, offering the potential for a lighter-weight and more compact fuel processing system.

- General Motors/Delphi tested two state-of-the-art 30-kW Ballard fuel cell stacks and designed and assembled a $50-\mathrm{kW}$ catalytic combustor for its fuel processor system.

- General Motors built and evaluated a complete, integrated 10-kW prototype fuel cell system (including a methanol fuel processor, shift reactor, preferential oxidizer unit, stack, air compressor, and system controls).

- Ford tested fuel cell stacks from four suppliers in Phase I (performance targets: $10 \mathrm{~kW}, 0.25 \mathrm{mg}$ $\mathrm{Pt} / \mathrm{cm}^{2}$, and $0.275 \mathrm{~kW} / \mathrm{kg}$ ) and selected two suppliers for Phase II (performance targets: $50 \mathrm{~kW}, 0.25$ $\mathrm{mg} \mathrm{Pt} / \mathrm{cm}^{2}$, and $0.367 \mathrm{~kW} / \mathrm{kg}$ ). 


\section{FIGURE 21}

Phase I PEM Fuel Cell Stacks Developed for Ford by Mechanical Technology, Inc., International Fuel Cells, and Energy Partners

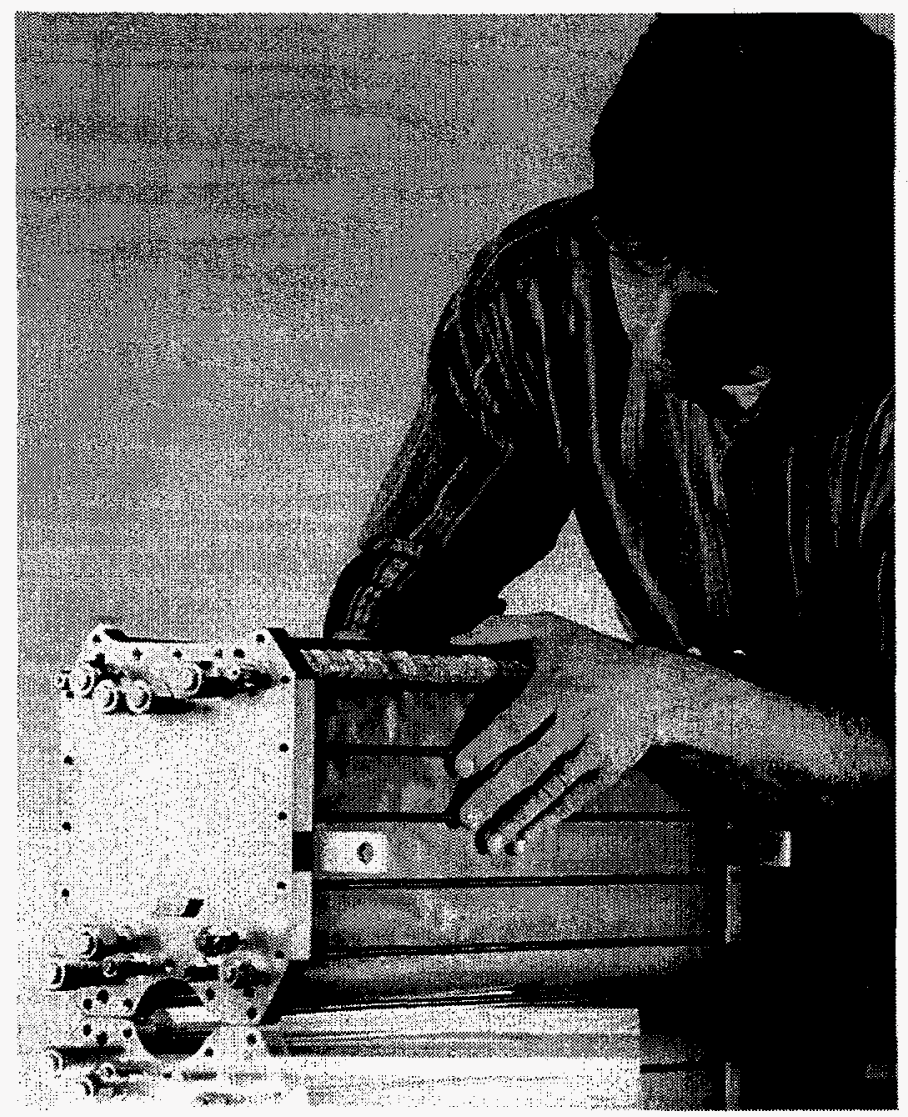

Mechanical Technology, Inc.

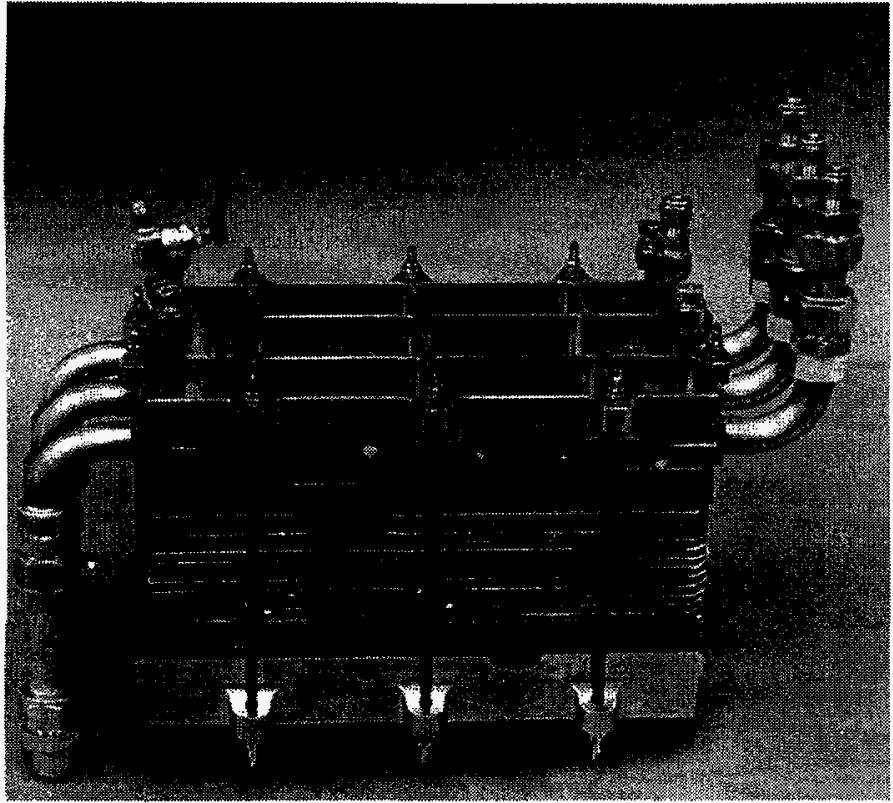

International Fuel Cells

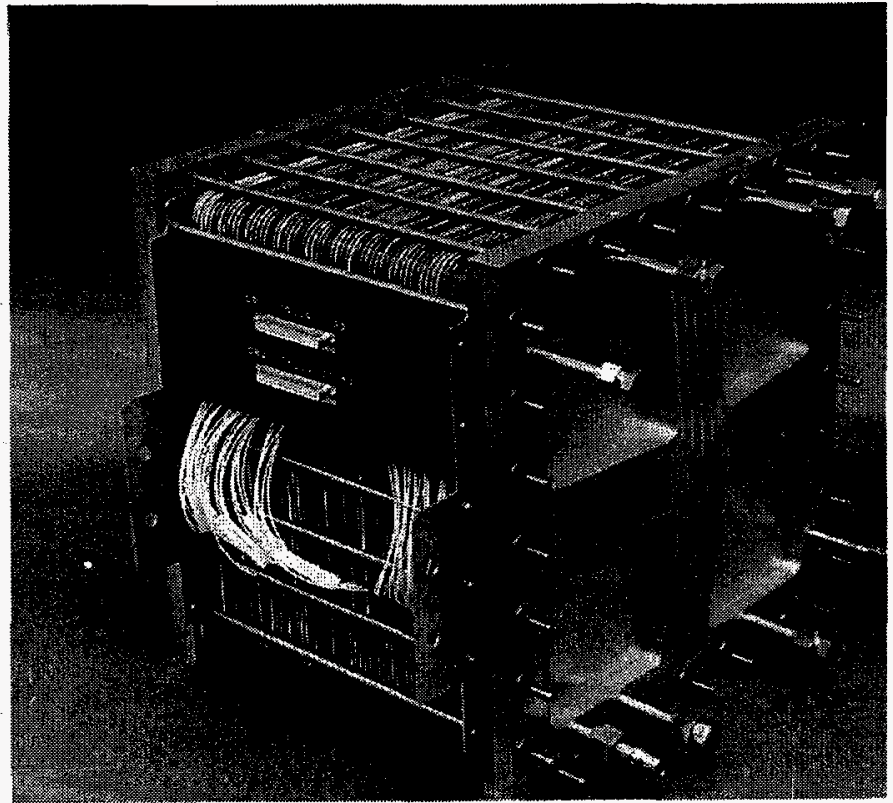

Energy Partners 


\section{FIGURE 22}

\section{Design-to-Cost Projections for AlliedSignal PEM Fuel Cell \\ Fabricated With Carbon-Coated or Conductive Plastic Bipolar Plates \\ (assumes production of one million units/yr)}

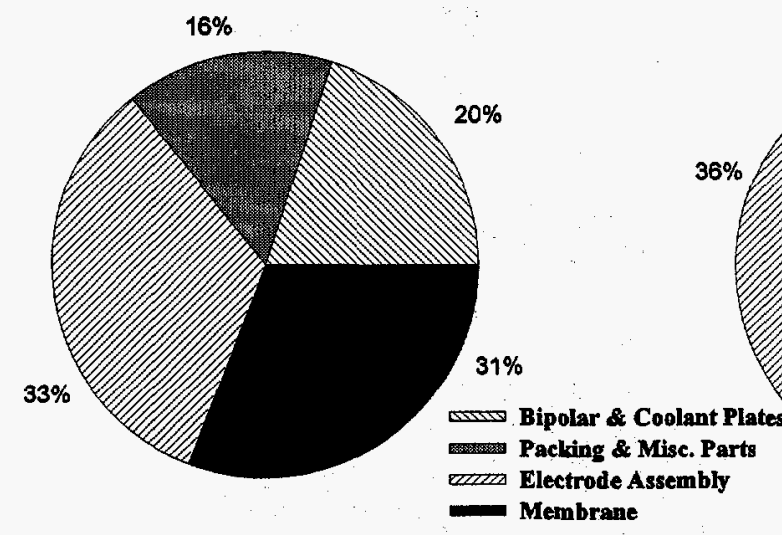

Carbon-Coated Metal Bipolar Plates Membrane $\$ 5 / \mathrm{ft}^{2}, \$ 73 / \mathrm{kW}$ Total
Conductive Plastic Bipolar Plates Membrane $\$ 5 / \mathrm{ft}^{2}, \$ 50 / \mathrm{kW}$ Total

- Lawrence Livermore National Laboratory, EDO Fiber Science, and Aero Tec Laboratories developed and fabricated prototype bladder-lined, composite tanks for on-board hydrogen storage under the Ford Program.

- AlliedSignal developed a lightweight, compact Prototype II baseline PEM fuel cell stack design of $0.62 \mathrm{~kW} / \mathrm{L}$ and $0.62 \mathrm{~kW} / \mathrm{kg}$ at $0.7 \mathrm{~mA} / \mathrm{cm}^{2}$ and $0.5 \mathrm{~V} /$ cell.

- AlliedSignal developed innovative lightweight carbon-coated and titanium-nitrided bipolar plates, and identified new canister/packaging and molded support plate materials, which are projected to increase the power density and specific power of its PEM fuel cell stack to $0.91 \mathrm{~kW} / \mathrm{L}$ and $0.78 \mathrm{~kW} / \mathrm{kg}$, respectively.

- Pentastar completed fabrication of the load leveler controller and chopper regulator that will be used for system-level testing of a 30-kW AlliedSignal PEM fuel cell stack in fiscal year 1997.

\section{FUEL PROCESSORS AND STORAGE}

\section{TECHNOLOGY BACKGROUND}

Fuel cells operate best on pure hydrogen. Using hydrogen stored on-board a fuel cell vehicle simplifies the propulsion system design and increases system efficiency by not requiring fuel to be processed onboard the vehicle. Because hydrogen is normally a gas, a relatively large volume is required to contain enough energy to provide the same driving range as today's automobiles. The two methods for storage of hydrogen on-board a vehicle that are receiving the most attention are compressed gas in storage tanks at high pressure and liquid hydrogen in insulated storage tanks at low temperature and pressure. Other storage methods based on metal hydrides, solid adsorbents, and glass microspheres have potential advantages but are not as well developed. Studies have shown that hydrogen storage systems can be engineered to be as safe as the fuel systems in current automobiles. Current compressed gas hydrogen storage systems are too bulky for automotive applications, limiting vehicle range. Higher pressure storage systems use expensive carbon fibers and composite tank liners. Less expensive materials and fabrication processes as well as more compact storage systems are required. 
On-board fuel processors need to be fuel flexible to use the existing conventional fuels infrastructure in the near-term while preparing for the transition to alternative and renewable energy sources in the longterm. In order for fuel cells to utilize fuels other than hydrogen, the fuel must be processed or reformed to provide a hydrogen-rich gas mixture. Catalysts are used to facilitate the chemical reactions. The two primary types of reformers being developed for transportation are steam reformers and partial-oxidation (POX) reformers. Steam reformers have higher efficiency, but POX reformers are simpler. Impurities in the reformate stream (primarily carbon monoxide) must be removed for the fuel cell to run effectively. This can be achieved with water-gas shift reactors, preferential oxidation reactors, or hydrogen separation membranes.

\section{PROGRAM ACTIVITIES}

Arthur D. Little, Inc. (ADL) of Cambridge, MA worked on developing a fuel flexible POX fuel processor to reform gasoline into hydrogen of sufficient purity for a PEM fuel cell. The 12-month Phase III effort in fiscal year 1996 builds upon the successful demonstration of a compact, highly integrated $50-\mathrm{kW}$ fuel processor optimized for ethanol fuel in Phase II (see Figure 23). The reformer technology can process a range of fuels including gasoline, ethanol, methanol, and natural gas.

Argonne National Laboratory (ANL) has developed a catalytic POX reformer for methanol that is very simple in design, construction, and operation (see Figure 24). The reformer operates at a very low temperature $\left(200^{\circ} \mathrm{C}\right)$ and involves no heat exchangers or fuel vaporizers, resulting in a start-up time under two minutes. It is controlled simply by varying the amounts of fuel and air fed to the reformer, much like the fuel and air feed control in today's fuel-injected cars. This technology was transferred to industry during fiscal year 1996, although some additional improvements are being sought in the laboratory. Some very promising results have been achieved in converting hydrocarbon fuels (gasoline, diesel) to hydrogen in the ANL laboratory reformer, but at higher temperatures and with catalysts that are different from the ones used for methanol.

LANL worked on the development of a preferential oxidizer system to reduce the carbon monoxide level to below $10 \mathrm{ppm}$ in the hydrogen-rich fuel stream leaving the fuel processor. This is essential since carbon monoxide will poison the fuel cell catalyst and degrade the performance of the fuel cell stack over time. The preferential oxidizer selectively converts the carbon monoxide to carbon dioxide without oxidizing the hydrogen in the fuel stream. During fiscal year 1996, LANL designed and developed a preferential oxidation system for integration with the ADL fuel flexible fuel processor.

\section{FISCAL YEAR 1996 ACCOMPLISHMENTS}

- ADL successfully completed testing of a 50-kW POX fuel processor with ethanol ( $85 \%$ efficiency and $1 \%$ CO output), demonstrating fuel flexibility.

- $\quad$ ADL developed and initiated testing of a fuel flexible $40-\mathrm{kW}$ POX fuel processor for gasoline $(0.7$ $\mathrm{kW} / \mathrm{L}, 0.6 \mathrm{~kW} / \mathrm{kg}$ ).

- ANL developed a low-temperature, catalytic POX fuel processor for methanol $\left(50 \% \mathrm{H}_{2}\right.$ and $0.8 \% \mathrm{CO}$ without shift reactor, $0.4 \% \mathrm{CO}$ with small shift reactor) that will reduce the start-up time of an integrated fuel cell power system to less than 2 minutes. ANL completed the transfer of catalytic methanol POX technology to General Motors. 
FIGURE 24

The Argonne National Laboratory 10-kW Low-Temperature

Partial-Oxidation Reformer

Under Laboratory Development

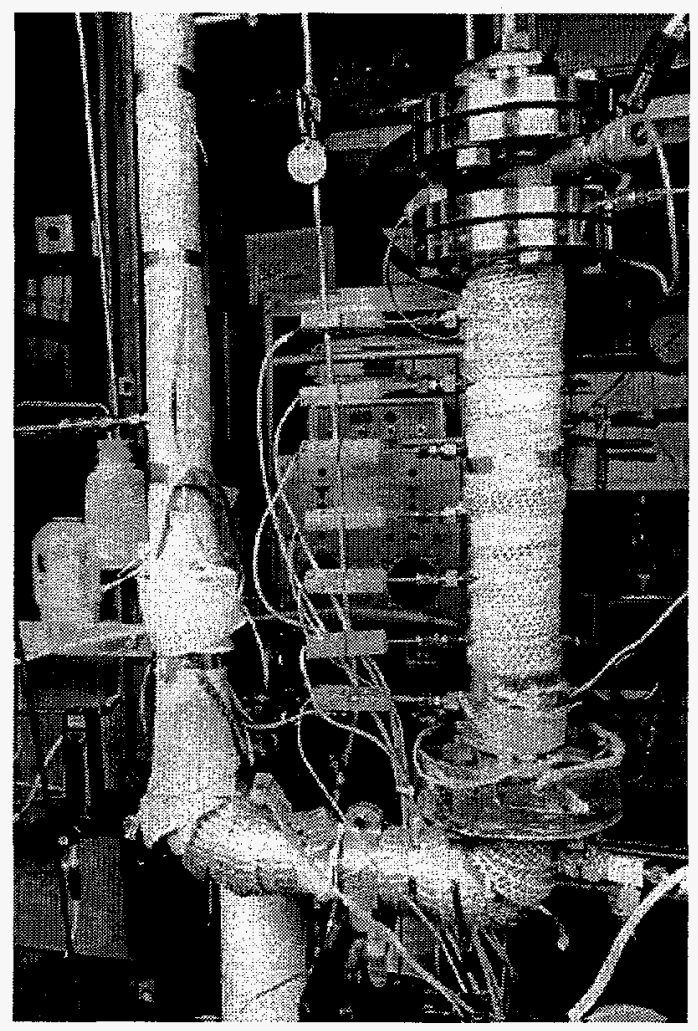

- ANL identified catalysts to selectively oxidize the carbon and release the hydrogen in hydrocarbon fuels, producing more than $40 \%$ hydrogen at a temperature less than $500^{\circ} \mathrm{C}$.

- ANL developed a dynamic (transient) model for methanol steam reformers. The model indicates that direct heat transfer systems can deliver fast start-ups and superior response compared to indirect heat transfer systems.

- LANL designed and developed a preferential oxidation system for integration with the ADL fuel flexible fuel processor.

\section{COMPONENTS}

\section{TECHNOLOGY BACKGROUND}

This program element supports the development of technologies for subsystems, components, and materials necessary to reduce costs, improve performance, and increase the reliability of PEM fuel cell power systems. The primary technical barriers are related to size and weight reduction, manufacturing cost reduction, start-up and transient response improvement, durability/reliability in automotive applications, and fuel processing and storage. Research and development to address these barriers is conducted by industry teams under cost-shared contracts and by national laboratory and university technical teams. Current and future areas of work that will be supported under this program element will address the development of lower-cost bipolar plates, better performing and lower-cost membrane-electrode assemblies, improved CO-tolerant fuel-cell catalysts, direct methanol fuel cells, and higher-efficiency compressor/expanders. Advances in technology will also be sought with respect to improved, integrated fuel-flexible fuel processors and carbon monoxide gas clean-up systems; improved shift reactor catalysts; and innovative concepts for fuel processors.

\section{PROGRAM ACTIVITIES}

A competitive solicitation resulted in six cost-shared contracts being awarded in fiscal year 1996. These contracts are described in this section. Three contracts were awarded to domestic fuel cell developers to incorporate innovative designs and materials into small fuel cell stack prototypes and to advance the state-of-the-art in PEM fuel cell technology. The three fuel cell contracts were awarded to Energy Partners, Texas A\&M University, and International Fuel Cells (IFC).

Energy Partners initiated an 18-month contract to advance PEM fuel cell technology in the areas of reactant flow field geometry, membrane electrode assemblies, and fuel cell and stack design. The goals for this program are to achieve a power density of $0.8 \mathrm{~kW} / \mathrm{L}$, a specific power of $0.8 \mathrm{~kW} / \mathrm{kg}$, and an estimated large-scale manufacturing cost of $\$ 30 / \mathrm{kW}$. Other members of the Energy Partners team are Florida Atlantic University, Southwest Research Institute, PSI Technologies, and Texas A\&M University.

Texas A\&M University began a 12-month contract to develop an advanced, near-ambient pressure PEM fuel cell for transportation applications. Features of the fuel cell include ultra-low platinum loading electrodes, advanced membranes, internally-humidified membrane electrode assemblies, and light, lowcost bipolar plates. 
A 12-month Phase I contract was awarded to IFC, to develop membrane and catalyst technologies for improving the performance and viability of direct methanol fuel cell technology for light-duty transportation applications. Other members of the IFC research and development team include the University of Connecticut, University of Iowa, and University of Southern Mississippi. Technical targets for the IFC direct methanol fuel cell are $310 \mathrm{~W} / \mathrm{L}, 445 \mathrm{~W} / \mathrm{kg}$, and a manufacturing cost under $\$ 110 / \mathrm{kW}$. The technical tasks are directed at developing membrane technologies that will reduce methanol crossover, anode catalysts with reduced polarization for oxidizing methanol, and cathode catalysts with improved oxygen reduction activity and lower methanol adsorption. Phase I of the project will culminate in the demonstration of selected advanced membrane technologies in single cells and the design of a $5 \mathrm{~kW}$ stack.

Three 15-month, Phase I contracts were awarded to develop three unique and innovative integrated compressor/expander technologies for supplying pressurized air to the fuel cells with the objective of improving the efficiency of the PEM stack system. An expander is required with all three compressor concepts to recover energy in the pressurized exhaust gas stream and thereby improve the overall efficiency of the system. In each contract, the developer is to design, fabricate, test, and deliver a prototype compressor/expander for use in a 50-kW PEM fuel cell system. The size and weight targets established by DOE for the compressor/expander are 4 liters and $3 \mathrm{~kg}$, respectively.

AlliedSignal was selected to develop an advanced turbocompressor, ADL to develop an advanced scroll compressor, and Vairex Corporation to develop an advanced multiple-piston device patented under the name Variable Displacement Compressor Expander ${ }^{\mathrm{TM}}$.

The main advantages of the AlliedSignal turbocompressor are in the areas of size, weight, and efficiency. Its biggest challenge is simultaneously maintaining fairly constant pressure ratio and high efficiency during turndown when the air flow rate is reduced well below its maximum design flow. The ADL and Vairex compressors are expected to meet the desired turndown characteristics, but will be challenged by the size and weight targets. Design reviews were held during fiscal year 1996 on all three compressor designs, and fabrication of hardware was initiated. The three systems are scheduled for delivery to DOE in fiscal year 1997.

In addition to the contracts with industrial fuel cell component suppliers, programs are in place with several of the national laboratories to address specific component and system related fuel cell technology barriers. An ANL program focuses on modeling of fuel cell systems for vehicular applications. These activities are in direct support of the major DOE programs at vehicle and fuel cell manufacturers (and their suppliers), but address balance-of-plant components and system start-up, operational, and loadfollowing issues. In addition to the development of quick starting, low temperature, and highly responsive fuel processors for converting methanol and other liquid fuels into hydrogen for use in PEM fuel cells (see section on Fuel Processor and Storage Research and Development), ANL is developing comprehensive systems models to analyze operating efficiencies of fuel cell propulsion systems as a function of design and operating parameters (cell voltages, operating pressures, fuel utilization, and component efficiencies) as well as operation at off-design power levels. Such analyses are useful in identifying the key sensitivities, as well as quantifying the advantages and disadvantages of proposed system modifications or of fuel cell or component improvements.

A program at LANL is seeking to improve the performance of PEM fuel cells operating on the hydrogenrich reformate from a fuel processor. The goals of the program are: (1) to enhance the tolerance of the PEM fuel cell to impurities in the reformate, such as carbon monoxide, which poison the fuel cell catalyst; (2) to develop low-cost lightweight bipolar plates; and (3) to develop novel schemes for humidifying the air and fuel streams to the PEM fuel cell, which is essential to keep the PEM membrane moist. During fiscal year 1996, stable performance of a PEM fuel cell was demonstrated for over 300 hours on a hydrogen-rich gas steam containing $100 \mathrm{ppm}$ of carbon monoxide, an order of magnitude higher than the generally accepted limit of $10 \mathrm{ppm}$. In the area of bipolar plate development, a 
microfiber/Kynar composite was identified as a promising material for the fabrication of thin, durable, low-cost, compression molded bipolar plates.

A second program at LANL is directed at the development of a PEM fuel cell that will operate directly on methanol (see Figure 25). This has the potential of significantly improving the specific power and the power density of an integrated PEM fuel cell power system by eliminating the fuel processor and associated ancillary equipment. During fiscal year 1996, methanol crossover from the fuel electrode to the air electrode in the direct methanol fuel cell (recognized as the key barrier to implementing the technology) was reduced by a factor of four. More than 500 hours of continuous operation of a direct methanol fuel cell was achieved with short-term demonstration of greater than $80 \%$ with a viable alternative proton conducting membrane.

Programs underway at Lawrence Berkeley National Laboratory (LBNL) and Brookhaven National Laboratory (BNL) are investigating technical barriers within the membrane/electrode assembly that limit the performance of the PEM fuel cell. During fiscal year 1996, LBNL developed a new technique for electrode evaluation, discovered a platinum-rhenium alloy with

FIGURE 25

Laboratory-Scale Development of a Direct Methanol Fuel Cell at Los Alamos National Laboratory

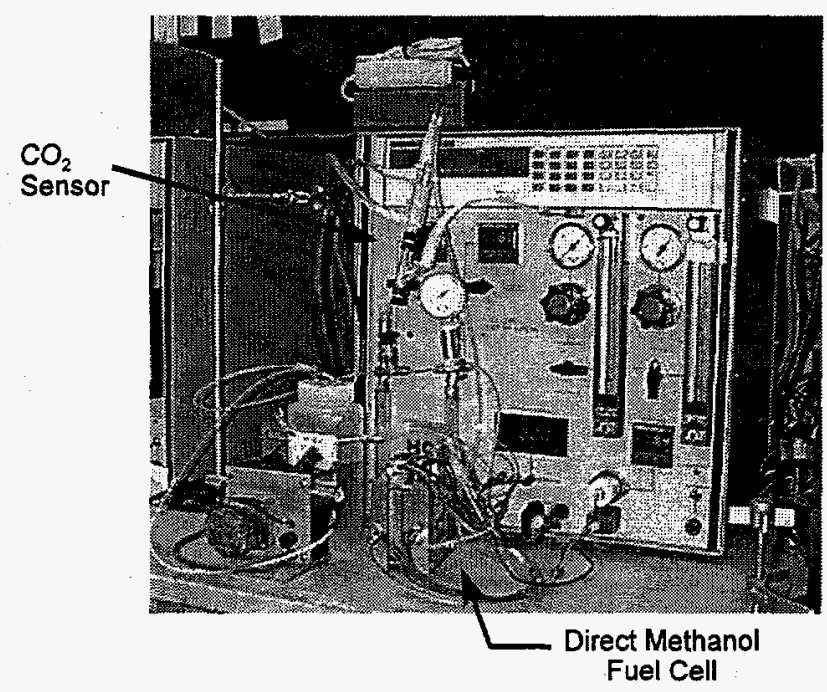
the lowest potential for $\mathrm{CO}$ oxidation ever reported, and developed a new theory of oxygen reduction on small platinum catalyst particles. BNL utilized x-ray absorption to increase understanding of PEM fuel cell catalyst activity and kinetics.

\section{FISCAL YEAR 1996 ACCOMPLISHMENTS}

- IFC has selected a set of baseline components, fabricated membrane electrode assemblies, and characterized them as a standard for comparison with direct methanol fuel cell alternatives; IFC has started producing and characterizing alternative membranes, as well as synthesizing new catalysts.

- ANL systems analysis demonstrated the sensitivity of overall system efficiency to the operating fuel cell voltage and the efficiency of compressor/expanders and determined the feasible combinations of fuel cell and battery size in light-duty hybrid vehicles.

- ANL completed characterization of novel cathode materials for ceramic fuel cells.

- The ANL battery test facility was modified to provide independent fuel cell testing capability; specifications for fuel cell specific test hardware were developed.

- LANL successfully demonstrated stable performance of a PEM fuel cell operating for more than 300 hours with $100 \mathrm{ppm}$ carbon monoxide in the hydrogen-rich fuel.

- LANL achieved continuous operation of a direct methanol fuel cell for 500 hours at $80^{\circ} \mathrm{C}$.

- LBNL and BNL utilized innovative analytical techniques to evaluate PEM electrodes and increase understanding of catalyst activity and kinetics. 


\subsection{AUTOMOTIVE MATERIALS}

\section{INTRODUCTION}

Timely availability of new materials and their manufacturing processes is critical for the development and engineering of advanced light-duty vehicles. A primary need is for lighter weight materials with sufficient strength and stiffness to replace conventional materials (i.e., mild steel) for body, chassis, and powertrain applications. An equally important need is for materials with optimum performance at operating conditions to enable advanced propulsion systems. The Office of Advanced Automotive Technologies (OAAT) is addressing these needs by sponsoring development of materials and materialsprocessing technologies, validating these technologies through representative component prototyping, and developing adequate design data to ensure their beneficial application. The OAAT Advanced Automotive Materials Program is working with the automotive industry, through the U.S. Automotive Materials Partnership (USAMP), to facilitate the development, by 2004 , of test-bed vehicles that are $40 \%$ lighter than current conventional vehicles with comparable capabilities. The focus of this program directly supports the Partnership for a New Generation of Vehicles (PNGV).

The OAAT Automotive Materials Technology Program focuses on two areas: (a) Lightweight Vehicle Materials and (b) performance-enhancing Propulsion System Materials. The Advanced Automotive Materials Program participants are listed in Table 12.

\section{LIGHTWEIGHT BODY, CHASSIS, AND ENGINE MATERIALS}

\section{TECHNOLOGY BACKGROUND}

Cost-effective processing and forming of lightweight material components will, in the near-term, incrementally improve the fuel economy of current production vehicles, and in the long-term, enable aggressive weight reductions needed by electric and hybrid electric vehicles. Research and development activities for structural materials are required in three areas: (a) vehicle structure (chassis, body panels, suspension systems, interior), (b) powertrain (engine blocks, motors, transmission housing, drivetrain), and (c) supporting systems (glass, alternative fuel systems, tires). For all materials research, it is important to address cost-effectiveness as well as recyclability, manufacturability, safety, and performance. Candidate lightweight materials include high-strength steels; aluminum alloys; magnesium alloys; titanium alloys; metal-matrix composites; polymers (reinforced, unreinforced, and selfreinforcing); ceramics; and various forms of carbon materials.

\section{PROGRAM ACTIVITIES}

Methods of processing and manufacturing using advanced low-density metals and alloys were developed to reduce component forming times, parts count, and production costs. Industry efforts were initiated to investigate the optimization of conventional forming processes as well as the development of new extrusion and warm forming processes for aluminum structural body components. In order to remove some of the economic barriers to increased use of lightweight metals in high-volume automotive production, efforts were initiated to develop low-cost continuous casting technologies for production of high-quality aluminum sheet and to develop a non-heat treatable aluminum alloy sheet product.

Development programs were initiated for cost-effective, high-volume, net-shape processing for aluminum and metal matrix composites. These include: (1) optimizing the design knowledge and ultimate product capabilities for lightweight (aluminum and magnesium), high-strength cast components; (2) investigating new low-cost powder metallurgy technologies for particle reinforced aluminum for producing wear resistant components with improved fatigue properties; and (3) developing methods to increase die life for die cast aluminum components. Figure 26 shows a cast aluminum control arm. 
TABLE 12

Advanced Automotive Materials

Fiscal Year 1996 Program Participants

\begin{tabular}{|c|c|c|}
\hline Participant Organization(s) & $\begin{array}{l}\text { runding } \\
\text { Mechanism }\end{array}$ & $\begin{array}{l}\text { Participant } \\
\text { Cost Share }(\%)\end{array}$ \\
\hline \multicolumn{3}{|l|}{ Lightweight Vehicle Materials } \\
\hline US Automotive Materials Partnership (USAMP) & Cooperative Agreement & 50 \\
\hline $\begin{array}{l}\text { Oak Ridge National Laboratory } \\
\text { US Council for Automotive Research (USCAR) }\end{array}$ & CRADA* & 50 \\
\hline $\begin{array}{l}\text { Pacific Northwest National Laboratory } \\
\text { USCAR }\end{array}$ & CRADA & 50 \\
\hline $\begin{array}{l}\text { Sandia National Laboratories } \\
\text { USCAR }\end{array}$ & CRADA & 50 \\
\hline $\begin{array}{l}\text { Idaho National Engineering Laboratory } \\
\text { USCAR }\end{array}$ & CRADA & 50 \\
\hline $\begin{array}{l}\text { Ames Laboratory } \\
\text { USCAR }\end{array}$ & CRADA & 50 \\
\hline $\begin{array}{l}\text { Los Alamos National Laboratory } \\
\text { USCAR }\end{array}$ & CRADA & 50 \\
\hline $\begin{array}{l}\text { Lawrence Livermore National Laboratory } \\
\text { USCAR }\end{array}$ & CRADA & 50 \\
\hline Lawrence Berkeley National Laboratory & Field Work Proposal & 0 \\
\hline Oak Ridge National Laboratory & Field Work Proposal & 0 \\
\hline Argonne National Laboratory & Field Work Proposal & 0 \\
\hline \multicolumn{3}{|l|}{ Propulsion System Materials } \\
\hline $\begin{array}{l}\text { AlliedSignal Engine } \\
\text { AlliedSignal Ceramic Components } \\
\text { Kyocera Industrial Ceramics }\end{array}$ & Contract & 30 \\
\hline $\begin{array}{l}\text { Allison Engine } \\
\text { Kyocera Industrial Ceramics }\end{array}$ & Contract & 20 \\
\hline AlliedSignal Engines & Contract & 27 \\
\hline University of Dayton Research Institute & Contract & 7 \\
\hline University of Michigan & Contract & 10 \\
\hline Oak Ridge National Laboratory & Field Work Proposal & 0 \\
\hline NASA-Lewis & Field Work Proposal & 0 \\
\hline
\end{tabular}

* $\quad \mathrm{CRADA}=$ Cooperative Research and Development Agreement

The development of reliable joining processes for dissimilar materials (aluminum, steel, polymer matrix composites) including laser welding, adhesive bonding, and mechanical fastening continued to be a focus of development efforts. Non-destructive evaluation (NDE) techniques were developed to assess the quality of cast components, fiber reinforced composites, joints, and installed parts.

Progress toward the development of polymer-matrix composites continued with the development of enabling technologies such as standard test methods for industry-wide implementation. Tensile test methods for adhesively bonded automotive composites subjected to ambient conditions were established. Test method development was begun for assessing the long-term environmental durability of adhesives 


\section{FIGURE 26 \\ Cast Aluminum Control Arm}

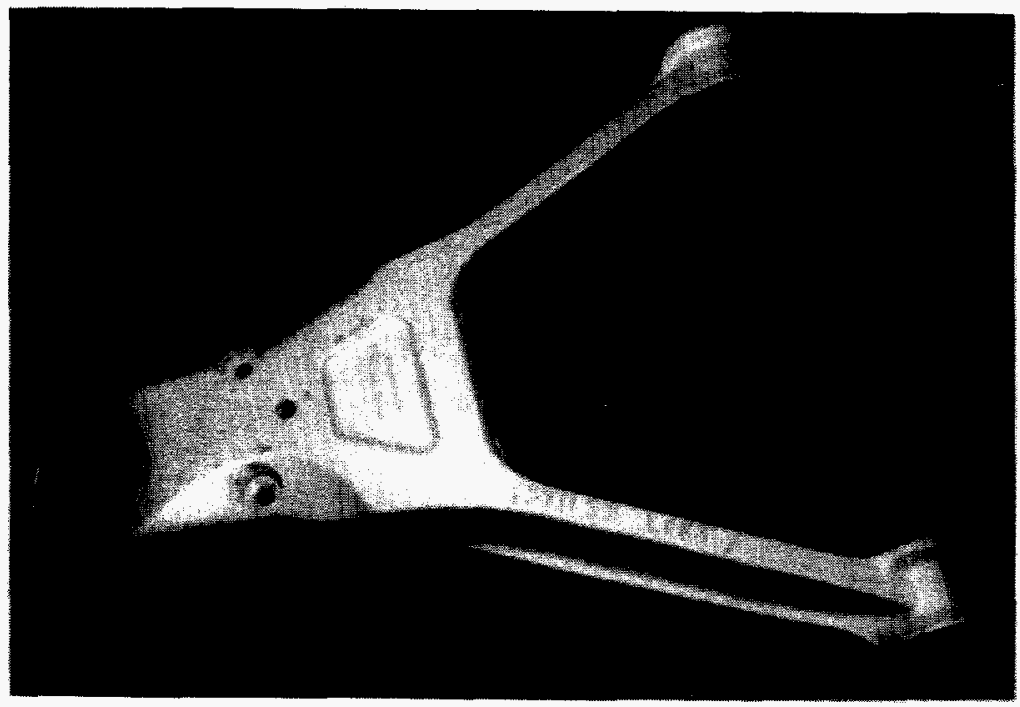

subjected to multiple environmental stressors and load histories. Modeling of water slurry preforming was initiated, enabling the prediction and tailoring of final preform density and compaction. Figure 27 shows a computational fluid dynamics model of this process. The model was developed by Idaho National Engineering Laboratory (INEL).

\section{FISCAL YEAR 1996 ACCOMPLISHMENTS}

- Achieved breakthrough in dimensionallyaccurate screen fabrication for slurry processing of fiber mattes for fiber reinforced composites.

- Specified fiber matte preform process and selected supplier to design and manufacture preforming system.

- Assembled and upgraded commercial shearography system for full-field NDE of adhesive bonding.

- Established core project team and performance requirements for powder metallurgy technology for particle reinforced aluminum; selected suppliers for powder consolidation technologies and raw materials; and selected suppliers for optimized tools and machining procedures.

- Developed industry-standard tests for durability of polymer composites for structural applications; completed tensile damage assessment; built $-40^{\circ} \mathrm{C}$ impact testing rig.

- Developed method for conducting Mode I fracture tests for adhesive bonding for automotive applications; initiated Mode II fracture test method development; and initiated long-term creep tests.

- Delivered completed test data to AlliedSignal Ceramic Components for fracture modeling of adhesive joints, and completed model development.

- Determined key compositional and microstructural factors governing non-heat treated aluminum sheet development and established test matrix for alloys and thermomechanical treatments.

- Developed standard product and process specifications for cast light metals; identified critical process and design parameters influencing
FIGURE 27

INEL Computational Fluid Dynamics Modell of "Slurry Process" for Fiberglass Preforming

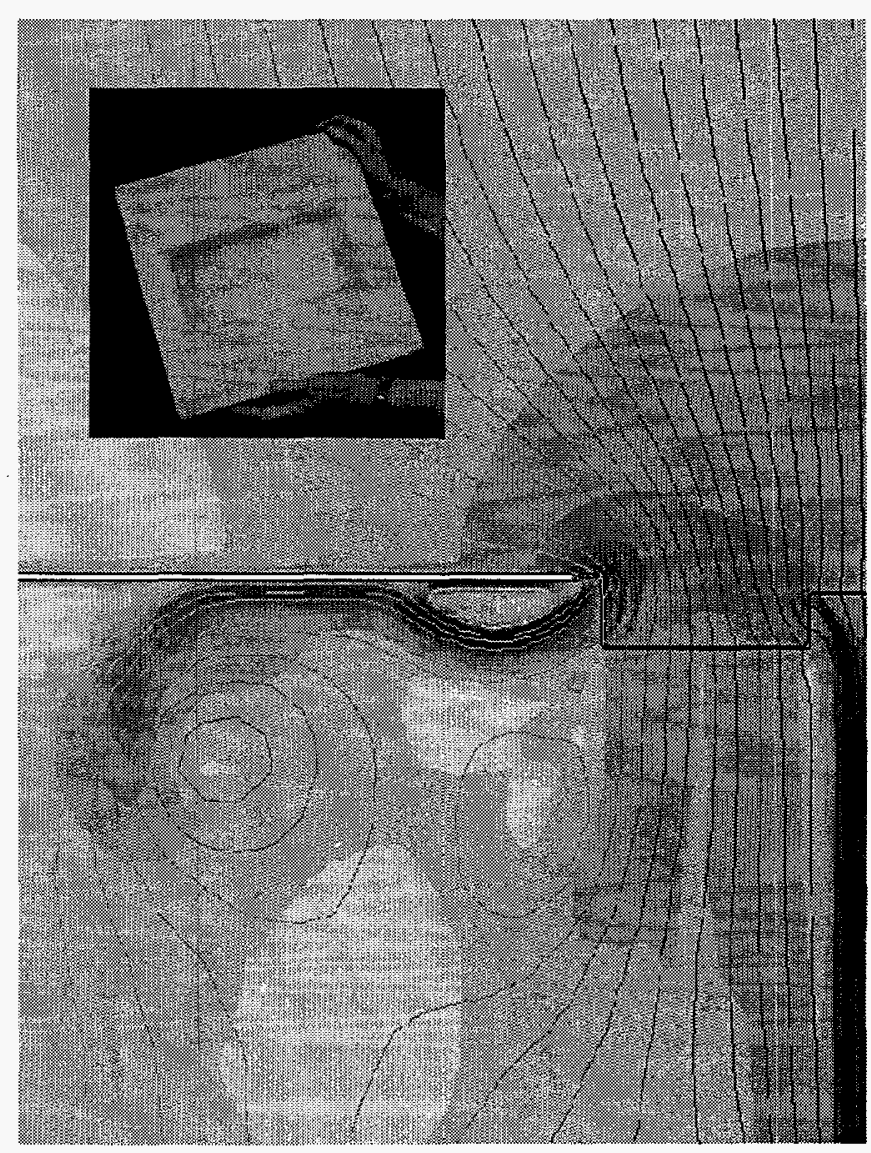


microstructure and materials properties for components cast in metal molds; and established specific light-metal structural casting design guide.

- Developed requirements definition for tools for rapid tooling for functional prototyping of metal mold processes; developed standards for samples to be produced using rapid prototyping; and established a system for sample testing.

- Developed technical comparison of aluminum sheet made by block continuous casting and conventional direct casting procedures.

- Initiated development of advanced forming technologies for aluminum automotive components and applications.

\section{PROPULSION SYSTEM MATERIALS}

\section{TECHNOLOGY BACKGROUND}

Materials for advanced powertrain systems contribute to the enhancement of vehicle propulsion system performance as well as the reduction of the overall vehicle weight. Advancements in propulsion system materials are needed in all powertrain components, including advanced heat engines (gas turbine; compression-ignition, direct-injection; and Stirling) as well as the supporting electronics and accessories. Structural ceramics are a key enabling technology for the success of gas turbine engines, which offer the promise of $40 \%$ fuel efficiency in steady-state operation. Ceramics facilitate high gas temperatures and hot-wall combustion, which are keys to achieving high efficiency and low emissions in gas turbines. After a successful 10-year effort that developed processing techniques that greatly improved the properties and reliability of ceramic materials, the program shifted its focus to reducing the cost of ceramic components, a key barrier to their commercial introduction into conventional heat engines. Research and development activities are ongoing in the technical areas of advanced ceramic manufacturing and cost-effective ceramics. These activities focus on: synthesis and processing; coating and joining; alternative forming and densification processes; NDE; mechanical property testing; and component verification and life prediction.

\section{PROGRAM ACTIVITIES}

Work continued on the ceramic component manufacturing scale-up by AlliedSignal Ceramic Components and Kyocera Industrial Ceramics. The fiscal year 1996 program goals for overall process yields of $50 \%$ at both suppliers were exceeded. Researchers at Oak Ridge National Laboratory (ORNL) worked in collaboration with ceramic suppliers to facilitate the scale-up and commercialization of the gelcasting process for low-cost fabrication of complex ceramic gas turbine components (see Figure 28). Gelcasting is a new forming process being commercialized by AlliedSignal Ceramic Components. AlliedSignal and ORNL won an IR-100 award for this process.

AlliedSignal Ceramic Components continued to obtain design data for its in situ toughened silicon nitride ceramic (AS800), including critical mechanical properties such as fracture toughness, slow crack growth rates, creep rates, Weibull modulus, and thermal conductivity. The material is intended for heat engine applications with a maximum use temperature of $1,400^{\circ} \mathrm{C}\left(2,550^{\circ} \mathrm{F}\right)$. The University of Michigan continued work to optimize silicon nitride ceramic properties for use at high temperatures through modifications of the grain boundary phase and microstructure.

Researchers from AlliedSignal Engines continued to develop the methodologies required to adequately predict the useful life of in situ toughened silicon nitride components in advanced heat engines. Additional research was begun to develop baseline information on the tensile stress-rupture and time-dependent creep behavior, and tensile and cyclic fatigue behavior of structural ceramics at room and elevated temperatures. 
FIGURE 28

ORNL Researchers Demonstrate the Gelcasting Process for Molding a Gas Turbine Rotor

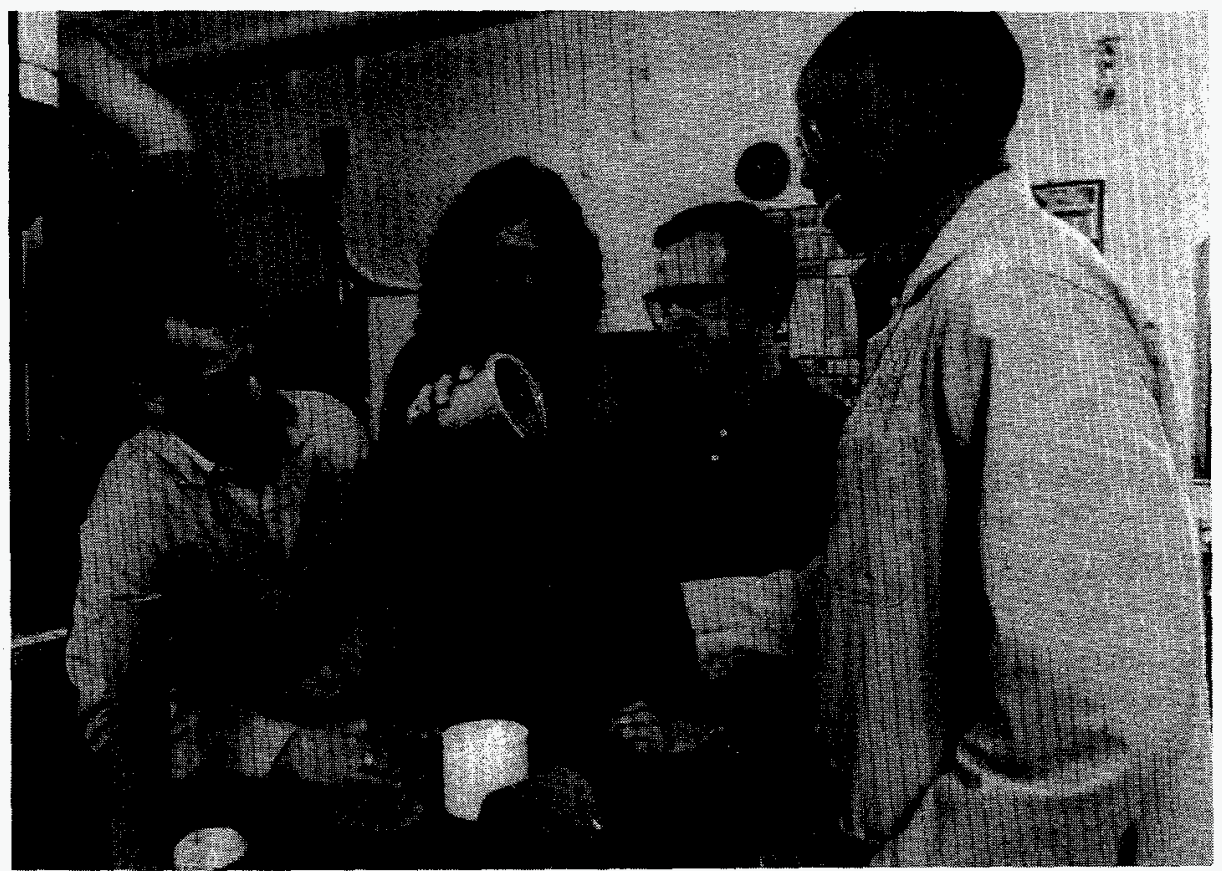

Efforts continued at ORNL to develop protective coatings to increase the durability of silicon nitride materials in hostile combustion environments (e.g., hot corrosion and active oxidation in salt environments).

\section{FISCAL YEAR 1996 ACCOMPLISHMENTS}

- Demonstrated that gelcasting has better uniformity (for increased Weibull modulus) and higher process yields than slip casting ( $4 \mathrm{X}$ better uniformity and $2 \mathrm{X}$ better process yield).

- Improved the mechanical properties of in-situ toughened silicon nitride to a level acceptable to engine manufacturers.

- Life prediction methodology for in-situ toughened silicon nitride was developed to the point that accurate results can be achieved for most fracture modes involving fast fracture.

- Demonstrated that initial chemical vapor deposition mullite coatings exhibited hot corrosion resistance in laboratory tests and in burner rig tests at AlliedSignal Engines.

- Developed test methodology for measuring tensile creep on small specimens cut from buttonhead tensile specimens.

- Developed an ultrasonic NDE technique that appears promising for detecting and quantifying the cumulative number of defects in the $20-200 \mathrm{~nm}$ range in simple-shaped silicon nitride specimens.

- Constructed a system for measuring high-frequency, cyclic fatigue of structural ceramics at frequencies of concern for gas turbines (up to $4 \mathrm{kHz}$ ).

- Published a compendium of data providing high-temperature flexural, tensile, and fatigue strength behavior of silicon carbide and silicon nitride ceramics. 
- Completed finite element analysis of a silicon nitride turbine rotor-to-metal shaft joint.

- Completed and reported simulations of four-point bend creep behavior of silicon nitride based on a viscoplastic creep model.

- Investigated Raman spectroscopy as a method for measuring residual surface stress in structural ceramics.

\subsection{ALTERNATIVE FUELS}

\section{INTRODUCTION}

The objective of the Alternative Fuels Program is to contribute to the reduction of the Nation's oil consumption, as well as environmental emissions, through increased use of high-performance, safe, and economical transportation vehicles that use alternative fuels. These fuels are derived either from renewable resources or from fossil fuels such as natural gas. Increased use of alternative fuels will require the establishment of viable vehicle production industries and extensive private sector investment in supporting infrastructure. Commercial markets will be viable when consumers have confidence in the performance, reliability, cost-effectiveness, and other characteristics of these vehicles. The Program works in partnership with engine manufacturers, automobile producers, research institutions, and fuel providers. The fuel spectrum includes natural gas, ethanol, methanol, propane, hydrogen, and dimethyl ether. Table 13 is a list of the Office of Advanced Automotive Technologies (OAAT) Alternative Fuels Program Participants for fiscal year 1996.

\section{LIGHT-DUTY VEHICLE ALTERNATIVE FUELS}

\section{TECHNOLOGY BACKGROUND}

The Department of Energy (DOE) has been developing alternative fuel technology in partnership with industry for over 20 years. The alternative fuels and vehicles are at many different stages of development. Many alternative fuel vehicles (AFVs) have been commercialized, but they are not yet fully competitive with gasoline vehicles.

Each alternative fuel presents its own technical challenges to be addressed through research and development. For each fuel, the major goal is to develop AFVs having approximately the same ccst, range, performance, and acceptance as gasoline vehicles. Considerably more work will be required in future years to reach this goal.

The most immediate barriers for compressed natural gas (CNG) vehicles are high cost and limited range. One technical objective is to develop materials and manufacturing techniques that will reduce the cost of CNG on-board storage cylinders. The current incremental cost of CNG vehicles ranges from $\$ 4,000$ to $\$ 5,000$, with the cylinders accounting for a large percentage of the cost increment. Another objective is to develop and test integrated CNG fuel systems that will meet range, durability, and reliability requirements. Current dedicated CNG vehicles have a driving range between 75 and 150 miles.

Ethanol and methanol present challenges that include the need to improve cold-start performance and to improve vehicle efficiencies for neat $(100 \%)$ alcohol. Current vehicles exhibit reduced starting ability during the winter in cold climates on alcohol blends and for neat alcohol in all climates. The objective is to develop proven $-30^{\circ} \mathrm{C}$ cold-start capability for alcohol vehicles. Current alcohol automotive engines have a potential for increased efficiency levels. The objective is to improve neat alcohol vehicle efficiencies by as much as $15 \%$. 
TABLE 13

Alternative Fuels

Fiscal Year 1996 Program Participants

\begin{tabular}{|c|c|c|}
\hline Participant organization(s) & I funding & $\begin{array}{l}\text { Participant } \\
\text { cost Share } \% \text { ! }\end{array}$ \\
\hline \multicolumn{3}{|l|}{ Compressed Natural Gas } \\
\hline Johns Hopkins University & Contract & 40 \\
\hline \multicolumn{3}{|l|}{ Ethanol } \\
\hline Southwest Research Institute & Contract & 20 \\
\hline Colorado School of Mines & Contract & 0 \\
\hline A.D. Little, Inc. & Contract & 25 (In-kind) \\
\hline University of Tennessee & Contract & 0 \\
\hline Nexum Research Corporation & Contract & 0 \\
\hline National Renewable Energy Laboratory (NREL) & Field Work Proposal & 20 \\
\hline \multicolumn{3}{|l|}{ Liquefied Petroleum Gas } \\
\hline Impco Technologies, Inc. & Contract & 50 \\
\hline Thiokol Corporation & Contract & 20 (In-kind) \\
\hline \multicolumn{3}{|l|}{ Hydrogen } \\
\hline University of Miami & Contract & 0 \\
\hline \multicolumn{3}{|l|}{ General Alternative Fuels Technology } \\
\hline University or College & Contract & 0 \\
\hline Southwest Research Institute & Contract & 0 \\
\hline
\end{tabular}

The current goal for liquefied petroleum gas (LPG, or propane) vehicles includes increasing fuel system integrity. LPG fuel systems for storage, delivery, and injection exhibit less durability than gasoline fuel systems because of their relatively early stage of development. The objective is to bring the fuel system components to competitive levels for durability and reliability, with increased efficiency.

\section{PROGRAM ACTIVITIES}

\section{Compressed Natural Gas}

\section{Advanced Natural Gas Vehicle}

The Johns Hopkins University is conducting a project to develop, test, and evaluate a natural gas compact sedan addressing the combined issues of operating range (over 300 miles), exhaust emissions, performance, useable trunk space, and safety in a collision. A 300-plus mile range compact vehicle has been demonstrated in the project, and future work is anticipated for an Integrated Storage System (ISS) as a joint effort between Lincoln Composites and the Applied Physics Laboratory at Johns Hopkins University. The ISS design will be generic with respect to light- to medium-duty vehicles and will be integrated into a Chrysler Corp. Breeze mid-size sedan next year. Figures 29 and 30 show the design of the ISS and the changes to be made to the vehicle. 
FIGURE 29

Integrated Storage System CAD Assembly View

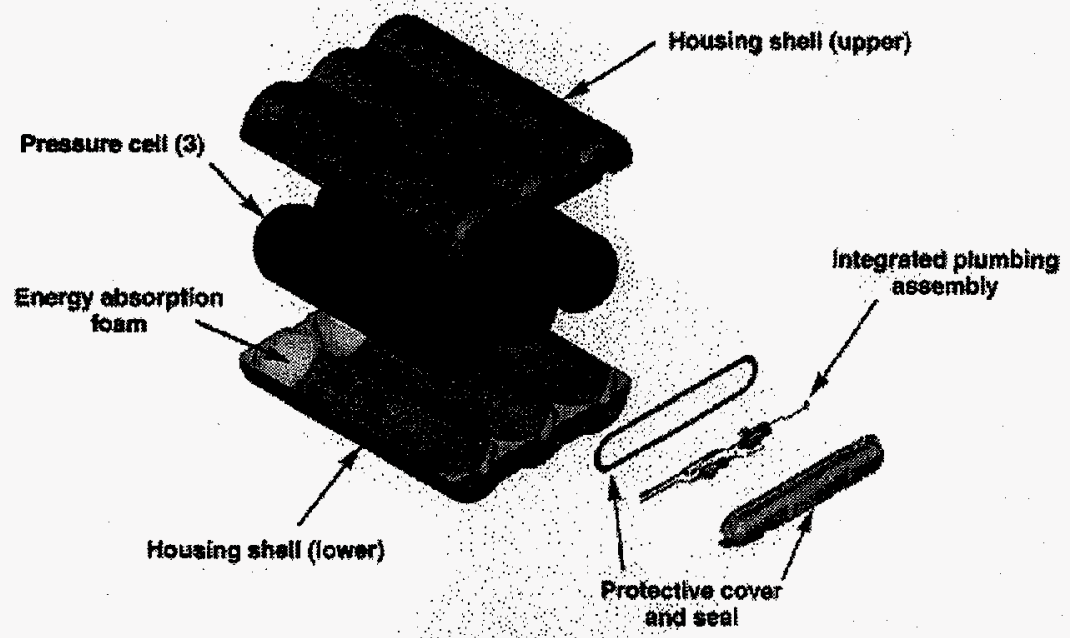

\section{Ethanol}

\section{Development of a Dedicated Ethanol Ultra-Low-Emission Vehicle}

Southwest Research Institute (SwRI) is conducting a project to develop a commercially competitive vehicle system, powered by ethanol, which will meet the California ultra-low-emission vehicle (ULEV) standards and equivalent corporate average fuel economy (CAFE) energy-efficiency standards for light-duty passenger car application. The design and components on an original equipment manufacturer's (OEM) flexible fuel vehicle are being modified to take full advantage of

ethanol's fuel properties. The vehicle modifications include changes to the engine, fuel injection, fuel transfer and storage, engine controller, exhaust, and catalyst system. After integration of the new components and systems, the vehicle was thoroughly tested and evaluated for emissions, performance, durability, and safety. SwRI completed engine calibration and installed the dedicated E85 engine in the vehicle. SwRI has demonstrated excellent emission potential of the engine on its engine test cell and will verify the test cell emission results with complete vehicle Federal Test Procedure (FTP) testing. SwRI showed emissions performance to be nearly an order of magnitude below the ULEV standard by using Variable Conductance Insulation Catalyst technology developed by the National Renewable Energy Laboratory (NREL). The Ford ULEV ethanol vehicle platform is shown in Figure 31.

FIGURE 30

Advanced Natural Gas Vehicle Design

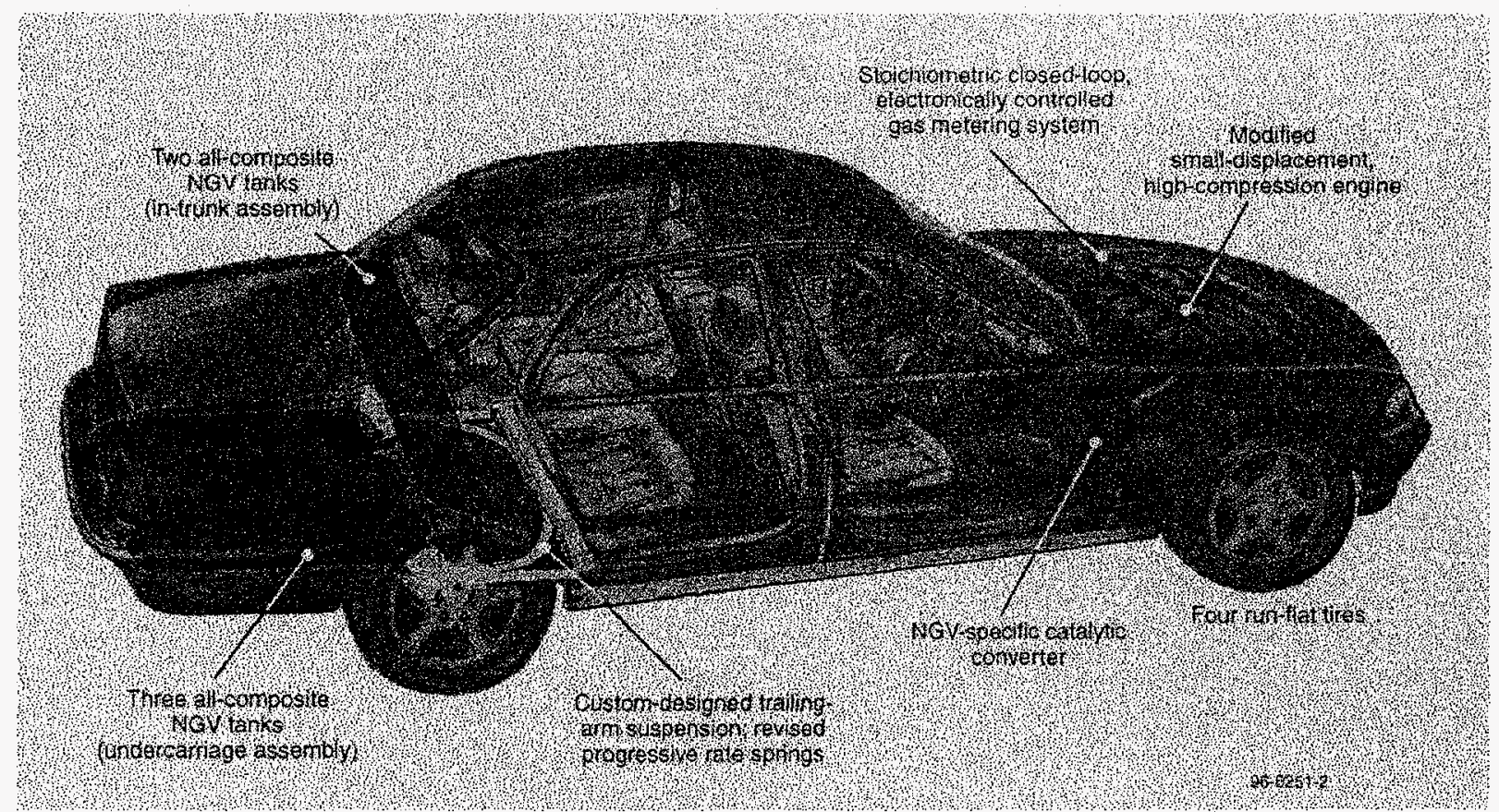


Ford ULEV Ethanol Vehicle Platform

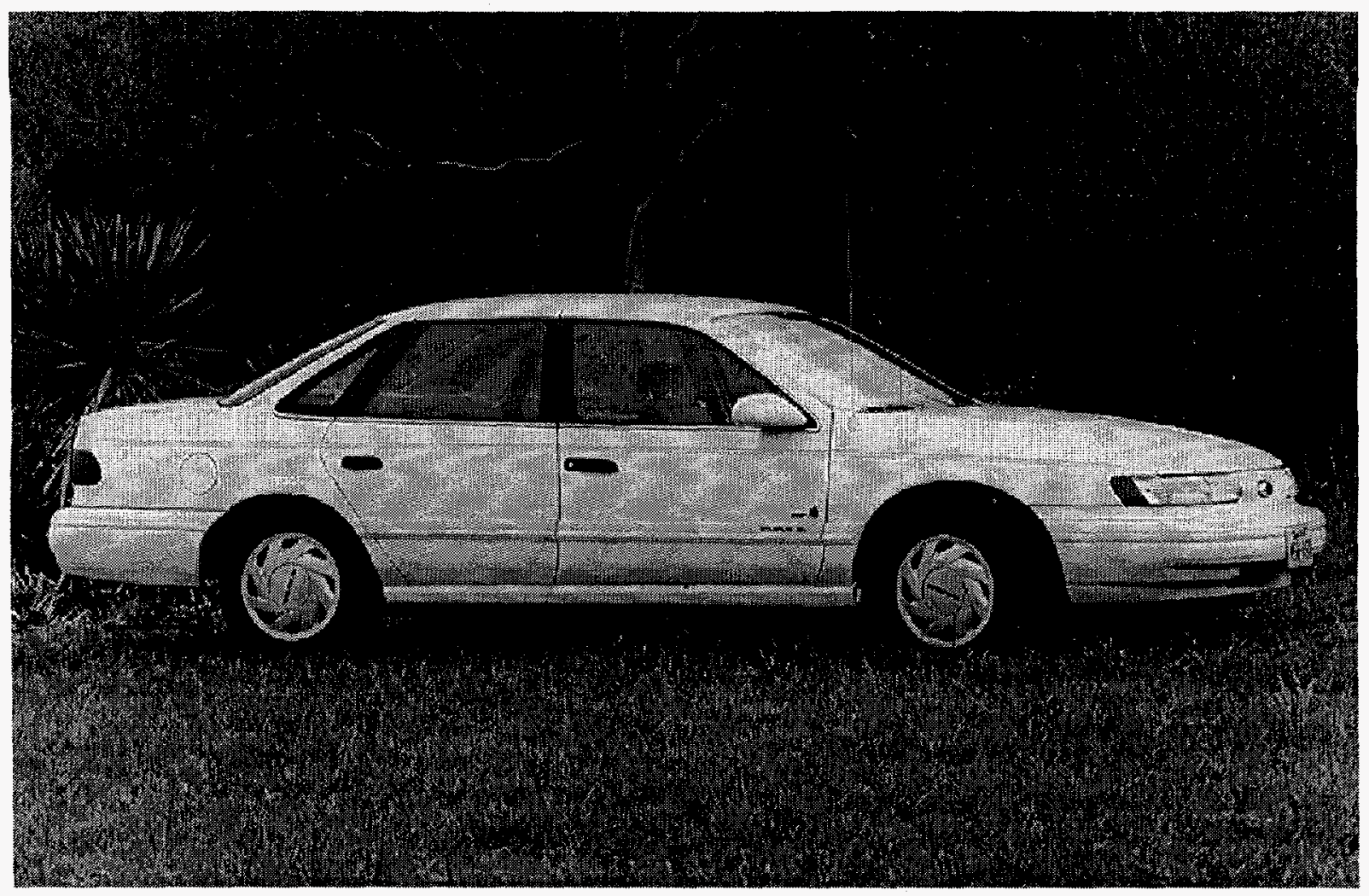

\section{Generation of Ethyl Ether in an Ethanol Vehicle System for Cold-Start Assistance}

The Colorado School of Mines is conducting a project to develop a simplified ethanol dehydration process to generate ethyl ether in an on-board vehicle system to provide cold-start capability when near neat ethanol fuel is used. Ethyl ether has historically been used as a primer for starting gasoline engines.

To avoid a two-fuel distribution system, new technology is needed to process ethanol onboard the vehicle to generate ethyl ether. The process will use heat and power available on the vehicle after it is warmed up and generate sufficient ether to provide cold-starts as needed. Catalytic conversion of alcohols for automotive applications has been an area of specialty for the Colorado School of Mines Department of Chemistry. Several catalyst systems have been screened for this project. Effects of side reactions and contaminants on the catalytic reactions have also been reviewed. Ethyl ether conversion has been shown to be a function of catalyst acid strength. A superior acid catalyst was demonstrated with high conversion efficiency and selectivity. It will also perform well under a wide temperature range.

\section{Partial-Oxidation for Improved Cold-Start in Alcohol Fueled Engines}

Arthur D. Little, Inc. (ADL) is conducting a project to develop neat alcohol, partial oxidation (POX), reforming technology -- with the specific purpose of developing a compact, on-vehicle, ethanol POX reactor as a fuel system component to increase an alcohol engine's low-temperature starting ability while reducing emissions. ADL demonstrated the feasibility of the POX technology to cold-start a neat ethanol fueled vehicle, and then designed, fabricated, and demonstrated an integrated POX system for automotive application. The project is split into two phases: verification and demonstration. ADL has demonstrated rapid engine start (less than 5 seconds) with simulated POX products. Based on these preliminary experiments, a simple and compact prototype POX reactor has been designed and fabricated as shown in Figure 32. 
FIGURE 32

ADL Compact Prototype

Partial-Oxidation Reactor

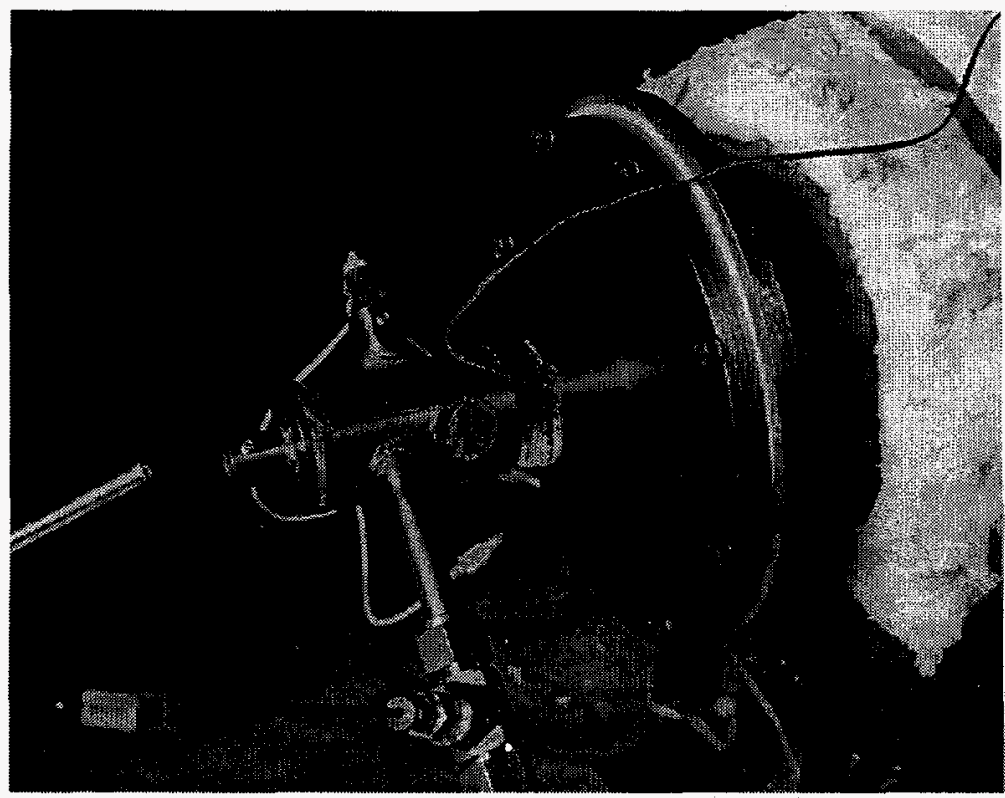

Investigation and Demonstration of a Rich Combustor Cold-Start Device for Alcohol Fueled Engines

The University of Tennessee is conducting a project to design and develop a rich combustor system for neat alcohol engines and to demonstrate the system on a vehicle. The purpose of the rich combustor is to increase the cold-start ability of a spark-ignited engine on alcohol fuels while reducing cold-start emissions. The University of Tennessee used a basic design for the rich combustor apparatus and performed initial proof-of-concept testing. The project includes the following five tasks: (1) modeling, (2) prototype design and fabrication, (3) prototype testing and evaluation, (4) vehicle interface and testing, and (5) emission testing. The first three tasks involved both methanol and ethanol; tasks 4 and 5 will be done for ethanol only. The University of Tennessee has installed the prototype combustor on the engine and has completed a series of ambient temperature tests to establish various test parameters. Low-temperature testing has also been completed.

\section{Fabrication and Testing of an Enhanced Ignition System to Reduce Cold-Start Emissions in an Ethanol (E85) Light-Duty Truck Engine}

Nexum Research Corporation, Thermotech Engineering Division is conducting a project to develop and test an enhanced ignition system that will reduce start-up emissions of high ethanol content (E85) fueled vehicles. The specific goal of the project is for an E85 vehicle with an enhanced ignition system to meet or approach ULEV emissions levels without using a large amount of ignition energy. Also, the enhanced ignition system will demonstrate if the cost is competitive with an electrically heated catalyst system. Initial steady-state testing was performed to determine the relationship between engine-out emissions and calibration parameters such as air/fuel ratio, spark timing, and ignition system discharge. Thermotech has completed build-up of the 4-cylinder test engine. Cold-start steady-state testing of the enhanced ignition system has been completed with E85. For comparison, additional testing of the ignition system was completed with neat ethanol and gasoline.

\section{Integration of Ethanol Vehicle Technologies}

NREL is conducting a project to apply engine modeling and simulation as a tool for evaluating performance of several cold-start technologies for alcohol fuels. The engine and combustion processes can be represented with available engine simulation software packages. For validation purposes, the simulation models will be compared with data developed in laboratory projects. The investment in engine modeling will reduce the need for numerous and costly hardware modifications to experimental vehicles, while providing a powerful and effective design tool.

\section{Liquefied Petroleum Gas}

\section{Development of a Dedicated LPG Ultra-Low-Emission Vehicle}

Impco Technologies, Inc. is conducting a project to develop a commercially competitive vehicle system powered by LPG that will meet the ULEV standards and equivalent CAFE energy-efficiency standard for 
a light-duty passenger car application. Impco has completed and installed the LPG fuel delivery system on the vehicle. This system includes the multi-point fuel-injection rail, the dual air/mass sensors, and a newly designed regulator. Impco is also developing its own electronic control module (ECM) to replace that of the OEM and has redesigned the inlet manifold to enhance even fuel distribution. Impco is currently driving the vehicle to test and verify the engine calibrations made in the test cell. An improved calibration system for the prototype injectors resulted in much better fuel control performance. The installation of close coupled catalyst has proved to be very effective in reducing cold-start emissions. Impco has performed FTP emissions tests on the vehicle, and ULEV levels have been met. The Chrysler platform for the ULEV LPG vehicle is shown in Figure 33.

\section{FIGURE 33}

Chrysler ULEV LPG Vehicle Platform

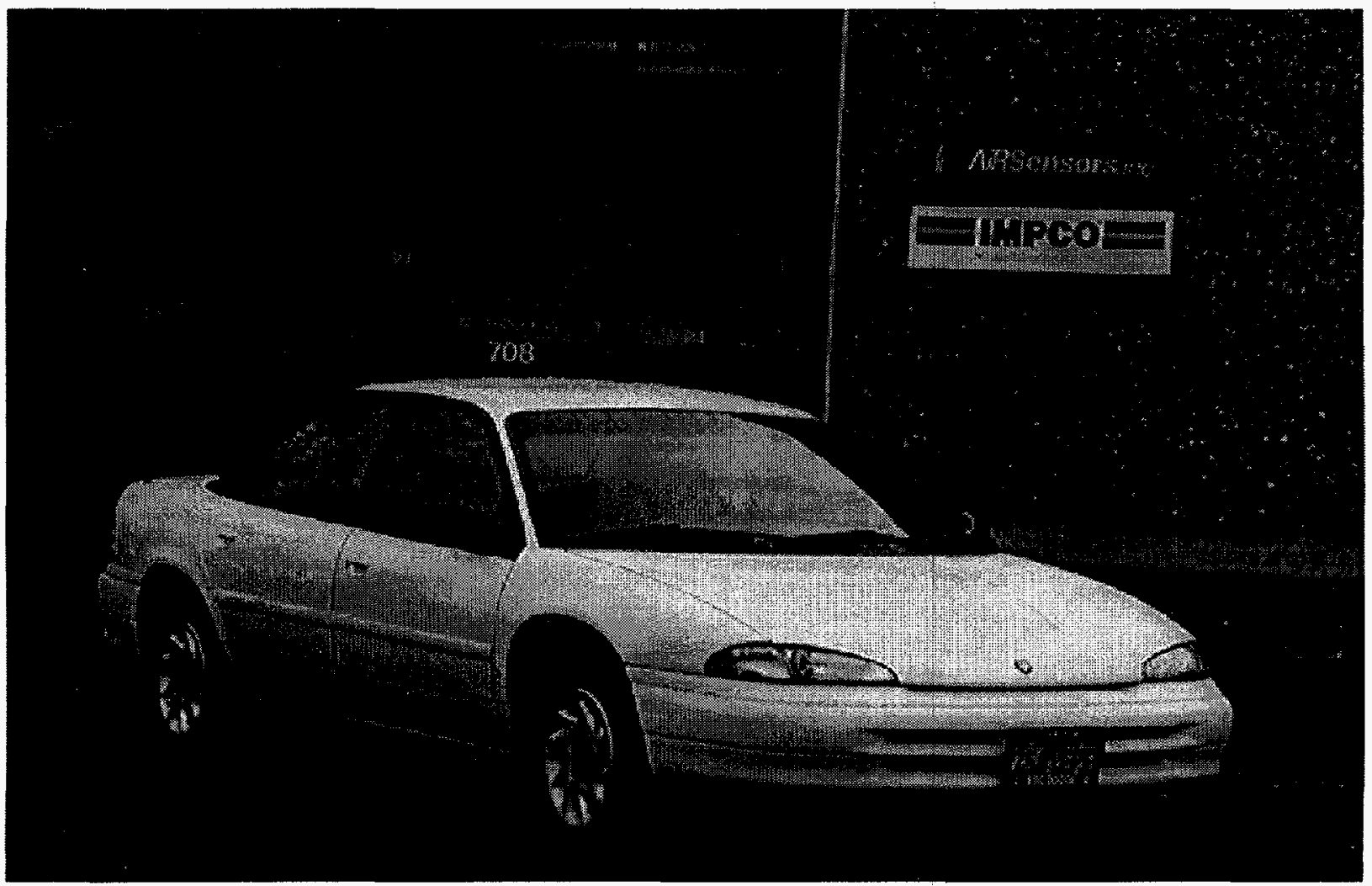

\section{Low-Cost Conformable Storage to Maximize Vehicle Range}

Thiokol Corporation is conducting a project to develop propane tank technology that will increase LPG vehicle range while reducing initial cost. The tank technology will be a low-cost, injection-molded, conformable (non-cylindrical) storage system. For this project, Thiokol investigated the use of low-cost, injection-molded thermo-plastic materials for gaseous fuel storage. The project includes system design, fabrication of subscale tanks, experimental testing, and demonstration. Thiokol has finalized the prototype tank design with Hettinga, an expert in injection molding of thermoplastics. The molds have been completed and initial prototype tanks were produced. Thiokol performed initial burst tests to evaluate the tank design. The initial tanks met $50 \%$ of the design test strength. Thiokol is investigating material and processing changes that will improve these results. Thiokol is also working with Chrysler Canada to supply the aluminum version of the conformable LPG tank for Chrysler's 1996 van project. 


\section{Hydrogen}

\section{Elimination of Abnormal Combustion in a Hydrogen-Fueled Engine Technology Demonstration}

The University of Miami conducted a project to determine whether a dedicated hydrogen-fueled engine can operate efficiently under a heavy load for normal driving conditions and still emit low oxides of nitrogen (NOx). An engine was constructed to suit the combustion properties of hydrogen. The design required the machining of a three-valve, two-spark plug aluminum billet cylinder head that incorporated machined cooling passages to eliminate film boiling. The engine was tested successfully under both light and heavy loads.

\section{General Alternative Fuels Technologies}

\section{Fundamental and Applied Alternative Transportation Fuel Research}

NREL issued a Letter of Interest Solicitation to universities and colleges for Fundamental and Applied. Alternative Transportation Fuel Research. At least one award is anticipated for research related to alternative fuel utilization in light-duty vehicles. The work will either provide fundamental scientific data or develop applied technology.

\section{Maintenance and Operation of the DOE Alternative Fuels Center}

SwRI is conducting a project to maintain and operate the DOE Alternative Fuels Center as a national resource that provides test fuels for research. Operation of the DOE facility includes maintaining equipment, controls, structures, storage vessels, and instruments.

\section{Oxygen-Enrichment Studies of Alternative Fuel Vehicles}

Argonne National Laboratory conducted a project to examine the potential merits of enriching combustion air with oxygen to reduce carbon monoxide ( $\mathrm{CO}$ ), hydrocarbons ( $\mathrm{HC})$, air toxics, and aldehyde emissions, particularly during the first 30-60 seconds of the cold-start in a methanol flexible fuel vehicle. The test results indicate that $\mathrm{CO}, \mathrm{HC}$, and air toxic emissions were considerably reduced, especially during the cold-phase of the FTP cycle at $23 \%$ and $25 \%$ oxygen-enrichment levels with indolene as a fuel.

\section{FISCAL YEAR 1996 ACCOMPLISHMENTS}

- A CNG vehicle was demonstrated with a 300-mile range and with power and emissions performance comparable to conventional vehicles.

- A dedicated ethanol vehicle was developed and demonstrated to achieve emissions performance nearly an order of magnitude below the ULEV standard, using technology developed at NREL.

- A novel catalyst was developed to convert ethanol to ether onboard a vehicle to achieve lowtemperature vehicle-start capability.

- A partial oxidator reactor was demonstrated to provide vehicle start with neat ethanol at low temperature.

- A prototype rich combustor was demonstrated as a technique to achieve low-temperature vehicle starts with neat methanol fuels. 
- An enhanced ignition system designed to reduced cold-start emissions from alcohol vehicles was developed and demonstrated.

- A dedicated LPG vehicle was developed, with substantial cost sharing from industry, achieving ULEV emission performance.

- A prototype injection molded LPG tank was developed and tested to provide conformable storage on a vehicle.

- A new engine design was demonstrated to improve and control combustion stability of hydrogen.

- Oxygen enrichment was demonstrated as a technique to reduce hydrocarbon and carbon monoxide emissions in a methanol vehicle. 


\subsection{INTERNATIONAL UPDATE}

The issues that challenge the U.S. to aggressively pursue advances in automotive technologies also confront all other major developed countries. The automotive industries in many of these countries now have research and development programs on advanced heat engines, hybrid and electric vehicles, fuel cells, and alternative fuel vehicles. In many of these programs, the activities parallel those of the U.S. In some areas, however, the focus is somewhat different due to the differences in geography, demographics, environmental conditions, and access to fuel resources, as well as historical, cultural, and political factors. This section provides an overview of foreign automotive research and development activities.

Just as the U.S. has established joint programs between government and industry, the countries of the European Union support the European Council for Automotive Research and Development (EUCAR), an industry-led cooperative research and development effort. Japan's Ministry of International Trade and Industry (MITI) also supports the automotive industry in an effort to further automotive technology in that country.

Improving fuel economy and reducing emissions are the major challenges facing the automotive industry around the world. For example, the German government has proposed a requirement for a $25 \%$ decrease in carbon dioxide emissions from all energy consuming sectors by 2005 , compared with the figures in 1990. The German Automobile Association has agreed on a goal of a $25 \%$ decrease in specific fuel consumption for new vehicles, during the same time frame. A more recent proposal in Europe calls for a fuel consumption reduction of $15 \%$ between 1995 and 2005, comparable to the German proposal. Discussions in Europe on a " $3 \mathrm{ltr} / 100 \mathrm{~km}$ vehicle," a target that is comparable to the $80-\mathrm{mpg}$ fuel economy goal of the U.S. Partnership for a New Generation of Vehicles initiative, is finding considerable interest in the press and with the public.

Many countries have proposed increasingly more stringent emission regulations for the future, which are similar to those in the U.S. However, these emissions regulations cannot be directly compared to those in the U.S. because of differences in driving cycles and test procedures. Exhaust emission regulations in Europe, for instance, take into account that proven technologies for oxides of nitrogen aftertreatment for lean-burn combustion systems do not currently exist. Therefore, the 1996 emission limits for oxides of nitrogen are less stringent for diesel cars than for gasoline cars.

The average percentage of diesel cars in new car sales in Europe has been steadily increasing since 1989, and a further increase is expected from $22.7 \%$ in 1994 to $30 \%$ in 2004. In Japan, diesel engines are a popular option for sport utility vehicles. The popularity of diesel powered light-duty vehicles in Europe and Japan is primarily due to a significant difference in fuel prices between gasoline and diesel fuels. If one considers both the higher cost of gasoline compared to diesel fuel, and the improved fuel economy of a diesel passenger car, the consumer can realize a significant operational cost savings with diesel-fueled light-duty vehicles.

\section{HYBRID ELECTRIC VEHICLES AND COMPONENTS}

Toyota introduced the "Prius" hybrid electric vehicle in 1995 . This parallel concept hybrid vehicle is a five-passenger sedan that employs a direct-injection 1.5 liter engine, a continuously variable transmission, lead-acid batteries, an induction motor/generator, and regenerative breaking. The prototype vehicle utilized ultracapacitor energy storage. The fuel economy for this $3,200 \mathrm{lb}$ vehicle has been reported to be in the 54 to $68 \mathrm{mpg}$ range.

Mitsubishi is currently field-testing prototype hybrid electric vehicles with two fuel types: gasoline and compressed natural gas (CNG). The gasoline-fueled vehicle has 28 prototype lead-acid batteries; the 
CNG-fueled vehicle has 30 prototype lithium-ion advanced batteries. The auxiliary power unit/generator is based on a Mitsubishi 1.5L passenger car engine that has been optimized for efficiency and low emissions. Emissions tests have been performed for both vehicle types. The CNG-fueled version has demonstrated exhaust emission levels below the California Air Resources Board proposed equivalentzero-emission vehicle (EZEV) standards. The gasoline-fueled version has demonstrated emissions close to the proposed EZEV standards.

Component technology is being conducted in Europe and Japan on high-power batteries, ultracapacitors, flywheels, power electronics, and electric machines. Japan appears to lead the market in power electronics, but both Europe and Japan are following the U.S. lead in high-power battery technology.

\section{ADVANCED HEAT ENGINES}

A four-year European Advanced Gas Turbine for Automobiles Program (AGATA) was initiated in January 1993 to develop three critical components for a $60 \mathrm{~kW}$ turbogenerator for a hybrid electric vehicle. The three ceramic components are a catalytic combustor, a radial turbine wheel, and a static heat exchanger. During the third year of the program, the design of the three critical components has been finalized, and experimental verification of the components has begun. An active catalytic material has been chosen and a full-scale catalytic combustor using a ceramic honeycomb substrate is being manufactured. Ceramic dummy turbine wheels have been manufactured from silicon nitride based materials that show very good mechanical properties. A complete quarter-scale ceramic matrix heat exchanger that is very resistant to transient thermal stress is also being manufactured.

In Japan, MITI has undertaken a ceramic gas turbine program as a national project. A $100 \mathrm{~kW}$ automotive ceramic gas turbine project was started in fiscal year 1990. Research and development is being conducted in the areas of advanced catalytic combustors for low oxides of nitrogen emissions, heat resistant lubricants, and ceramic materials for engine components. The goal is to achieve $40 \%$ thermal efficiency at a $1,350^{\circ} \mathrm{C}\left(2,462^{\circ} \mathrm{F}\right)$ turbine inlet temperature. Ceramic components have passed reliability and durability tests at $1,200^{\circ} \mathrm{C}\left(2,192^{\circ} \mathrm{F}\right)$ turbine inlet temperatures, and preliminary runs have been made at $1,300^{\circ} \mathrm{C}\left(2,372^{\circ} \mathrm{F}\right)$. Thermal efficiencies of $31.3 \%$ have been demonstrated at $1,170^{\circ} \mathrm{C}\left(2,138^{\circ} \mathrm{F}\right)$ turbine inlet temperature. Further development will be required before the target goal of $40 \%$ thermal efficiency at $1,300^{\circ} \mathrm{C}\left(2,372^{\circ} \mathrm{F}\right)$ turbine inlet temperature is met in a proven durable and reliable engine.

Direct-injection spark-ignition engines have been investigated for many years but have only recently shown promise as a next generation gasoline engine technology. Charge cooling with direct injection has been shown to improve volumetric efficiency and to reduce the mixture temperature at the time of ignition, allowing for operation with a higher compression ratio that improves the thermodynamic cycle efficiency. This technology promises $2 \%-3 \%$ improvement in volumetric efficiency at wide open throttle, 5\%-10\% increased power output, and 4\%-5\% improvement in part load fuel consumption when compared to a conventional gasoline engine calibrated for stoichiometric operation. A further gain of $6 \%-7 \%$ in fuel consumption is possible with lean combustion. All of the major automobile companies currently have development programs on direct-injection spark-ignition engines. Toyota Motor Corporation has reported that a newly developed four-stroke direct-injection engine will be installed in a compact or subcompact production car in the near future. However, it appears that much more research and development on emission control will be required before this type of engine will find widespread commercialization in automobiles.

Ongoing research and development programs are being conducted on a variety of variable valve timing and valve lift control strategies for improving engine performance, fuel economy, and emissions control. Examples of variable valve timing and lift control strategies that are being employed in production engines include Mazda's Miller cycle engine and Honda's lean-burn combustion system known as VTEC-E (variable valve timing and lift electronic control). In the Miller cycle engine, intake valve closing is delayed to reduce the effective compression ratio while keeping the expansion ratio high for improved fuel economy and engine performance. The variable valve timing and valve lift control in the 
VTEC-E engine accomplishes variable swirl control in the engine cylinder and allows for lean-burn combustion and improved fuel economy when compared to conventional engines.

Significant research and development is being done on direct injection diesel engines for light-duty vehicle applications, especially in Europe where the popularity of diesel powered passenger cars is increasing. Direct-injection diesel engines have about a $15 \%$ advantage in thermal efficiency when compared to the commonly used indirect-injection diesels. The long-term future of direct-injection diesel engines and lean-burn direct-injection gasoline engines appears to be dependent on the emergence of an efficient, reliable, and durable lean/NOx catalyst system for the control of oxides of nitrogen (NOx) to levels commensurate with future emission regulations. Passenger cars with direct-injection diesel engines have already been introduced into European markets.

\section{ELECTRIC VEHICLES AND BATTERIES}

The incentive to pursue electric vehicles in each country depends on the severity of the prevalent environmental conditions and the sources of electricity. Countries that are actively encouraging the use of electric vehicles include France, where electricity is generated largely by nuclear power plants, and in Sweden, where there is ample hydroelectric capacity, since the power required for battery recharging does not contribute to air pollution. Japan and many other countries also have strong interest in electric vehicles, due to traffic congestion and pollution in populated areas, typically shorter driving distances, the predominance of smaller vehicles, and the relatively high cost of gasoline (relative to the U.S.).

Many of the major automobile companies of Europe have development programs on electric vehicles. In countries such as France and Italy, where small vehicles and short ranges are commonplace in large cities, electric vehicles have been tested extensively. The Italian Agency for New Technology, Energy and the Environment has been conducting research and development activities in the transportation sector in order to improve energy savings and reduce environmental impacts.

Honda and Toyota have developed electric vehicles with nickel/metal hydride batteries and are planning market testing in the U.S. and fleet testing in Japan. Two Korean automakers have developed prototype electric vehicles as a part of their research and development programs. The number of electric vehicles in Japan rose from 1,541 in March 1993 to 1,946 in March 1994. However, various technical developments and improvements in drive units, batteries, and charging system performance will be necessary before electric vehicles will see widespread use in Japan.

Pilot manufacturing of a high-energy sodium/metal-chloride ZEBRA (Zero Emission Battery Research Activity) battery, developed by AEG and the Anglo American Corporation, was started last year in Ulm, Germany. The ZEBRA battery is reported to have a storage capacity four times higher than lead-acid batteries of the same mass. Last year, a ZEBRA equipped Mercedes Benz electric vehicle completed a three-year $100,000 \mathrm{~km}$ endurance trial that included 1,100 charging and discharging cycles.

Other European battery development work is being conducted by Varta (nickel-metal hydride and lithium-ion), SAFT (nickel-cadmium, nickel-metal hydride, and lithium-ion), and DAUG (nickelcadmium and nickel-metal hydride). The German Postal Service is engaged in a pilot project utilizing zinc-air batteries provided by Electric Fuel Co. of Jerusalem. This type of battery is mechanically rechargeable, in that an entire battery is removed from the vehicle and replaced with a battery that has been electrochemically reprocessed.

\section{FUEL CELL SYSTEMS}

Toyota has built a fuel cell powered, mini sport utility electric vehicle. The fuel cell is a compact unit operating on hydrogen, which is stored at moderate pressure and temperature in a powdered titanium alloy. The vehicle can be refueled in about 20 minutes, and Toyota claims an energy conversion efficiency of approximately $60 \%$. 
Matsushita Electric Works of Japan is currently using fuel cells manufactured by Ballard Power Systems of Vancouver, British Columbia in the development of portable power systems. Ballard fuel cells are also being used in the development of vehicles and stationary power plants by companies such as Daimler-Benz, General Motors, Hitachi, Honda, Volkswagen, and Volvo.

In April 1996, Daimler-Benz debuted a fuel cell powered six-passenger van known as NECAR II. The fuel is gaseous hydrogen and is stored at high pressure in roof-mounted tanks made from carbon-fiber reinforced plastic. The vehicle can reach speeds up to $100 \mathrm{~km}$ per hour and can travel up to $250 \mathrm{~km}$ without refueling.

\section{AUTOMOTIVE MATERIALS}

Advanced materials development is occurring in the automotive industry throughout the world in the development of new automotive products. Since 1979, the International Energy Agency has been implementing research projects to evaluate ceramic materials. Countries participating in the program include Belgium, Germany, Great Britain, Japan, Switzerland, Sweden, and the U.S. Both Japan and Europe have programs aimed at advanced materials development similar to that in the U.S., including work in lightweight materials (aluminum, magnesium, and plastics), as well as high-temperature ceramics. As a part of this effort, the National Research Council Chemistry Committee in Italy is sponsoring a feasibility study on Special Materials for Advanced Technologies. Both the European and Japanese automotive gas turbine projects contain significant advanced materials development components.

\section{ALTERNATIVE FUELS}

The type of alternative fuel favored in each country depends on the situation in that particular country. Dimethyl ether (DME) is of great interest in Europe because of the high use of diesel engines in lightduty vehicles. Sweden has a high interest in ethanol because of the lack of a resource base for other fuels. Countries such as Italy and New Zealand have a high interest in natural gas because of the availability of domestic natural gas resources. The interest in natural gas is high in many countries, but the cost of vehicle conversions and refueling infrastructure appears to be a significant deterrent.

The Canadian Government has long been a proponent of propane as a fuel for vehicles in its country, and considerable technology transfer has occurred between Canada and the U.S. The U.S. Department of Energy (DOE), Natural Resources Canada, and Chrysler Canada jointly sponsored the 1996 Propane Vehicle Challenge in Windsor, Canada to demonstrate that the performance of propane vehicles compared favorably to gasoline counterparts. During the competition, university teams achieved improved emissions and fuel economy and superior acceleration over the stock gasoline-powered vehicle.

BMW is now selling two CNG/gasoline bi-fuel passenger cars in Germany. These cars have "seamless switching" from natural gas to gasoline while the car is in operation. Although fuel consumption is similar to that of an equivalent gasoline powered car, significantly less carbon dioxide and hydrocarbons are emitted when operating on natural gas. Liquefied natural gas is seen as the next step after CNG, before the advent of hydrogen powered cars. BMW also has almost 20 years of experience with research and development of hydrogen powered cars, and road prototypes using modified gasoline engines, which have demonstrated the efficacy of hydrogen as a fuel and the low emissions potential of hydrogen powered cars.

The rotary Wankel type engine is being investigated by Mazda and others as a hydrogen fueled engine. The rotary engine tends to minimize most of the combustion difficulties associated with hydrogen fuel such as pre-ignition due to hot exhaust valves, hot spark plug electrodes, and combustion chamber deposits. In addition, very low levels of NOx emissions can be achieved with a hydrogen fueled rotary engine. 


\section{DRIVETRAIN COMPONENTS}

As with domestic automobile manufacturers, foreign manufacturers are improving fuel economy through a combination of engine and powertrain efficiency gains along with weight reduction, aerodynamic improvements, and a reduction in tire rolling resistance. Audi AG will soon introduce the world's first 5-speed automatic transaxle next year in a front-wheel drive vehicle. Renault is now offering a clutch-free manual transmission in a compact car in which the driver simply moves the lever, with no need to depress a clutch pedal.

Subaru, Nissan, and Honda are currently offering passenger cars and commercial vehicles in Japan employing continuously variable transmissions. Honda and Mitsubishi have developed direct yaw control systems that split and vary the driving torque unequally between the left and right wheels when cornering. The purpose of these systems is to improve vehicle stability during cornering. These systems are to be introduced into production in the near future in Japanese sport utility and high-performance vehicles. 


\subsection{CONCLUSION}

Considerable progress was made in fiscal year 1996 toward meeting the long-term goals of the Office of Advanced Automotive Technologies (OAAT). This report provides an overview of the technical and programmatic objectives, challenges, and accomplishments in each of the areas of OAAT responsibility, as summarized below.

\section{NATIONAL NEEDS}

The importance of the stated mission stems from the major challenges facing the U.S. in meeting the ever-increasing demand for transportation goods and services while striving to minimize adverse energy, environmental, and economic impacts. Over $97 \%$ of the fuel consumed by the U.S. transportation sector involves petroleum-based fuels, and this use accounts for two-thirds of the Nation's total oil consumption. Vehicle fuel efficiencies have shown steady improvement since the 1970 s, but increases in population and per capita miles driven have more than offset these gains, contributing to an overall increase in consumption of petroleum for transportation. The growing level of imported petroleum also represents a massive transfer of wealth from the U.S. to oil-exporting countries. Other major issues are the increasing global market competition in the automobile industry and the substantial contribution of the transportation sector to air pollution in the U.S.

There is a clear need to reduce the Nation's dependence on imported petroleum, while reducing air pollution, and ensuring U.S. competitiveness. The greatest opportunity for meeting these challenges is by increasing efficiency of automotive vehicles and increasing the utilization of domestic, renewable energy sources. OAAT strives to realize this opportunity by supporting programs for the development of hybrid electric vehicles, advanced heat engines, high-power energy storage systems, high-energy storage batteries, electric vehicle technologies, fuel cells and fuel processing systems, lightweight automotive materials, propulsion system materials, and alternative fuel vehicles.

\section{FISCAL YEAR 1996 ACCOMPLISHMENTS}

\section{VEHICLE SYSTEMS}

The hybrid electric vehicle development effort entered its fourth full year, with primary focus on work performed through cost-shared contracts with Chrysler, Ford, and General Motors, including more than 30 subcontracts with component and subsystem suppliers, small businesses, national laboratories, and universities. Fabrication and testing was performed for prototype advanced components, including gas turbine hybrid power units, a Stirling hybrid power unit, flywheel energy storage systems, high-power batteries, ultracapacitors, and power electronic devices. Modeling and simulation analyses were performed to ensure that integrated vehicle performance capabilities meet all requirements.

\section{ADVANCED HEAT ENGINES}

Advanced heat engine activities focused on the gas turbine hybrid power unit; advanced automotive piston engine; and combustion efficiency and emissions research and development. Durability testing was conducted on ceramic components for the gas turbine hybrid power unit and advances were made in manufacturing processes to increase production rates and reduce manufacturing costs of ceramic components. Emphasis has shifted from spark-ignition piston engine technology to compression-ignition, direct-injection technology. Advances were made in the development of improved manufacturing processes and engine diagnostic techniques. Work was also performed on improving catalysts for emissions control of oxides of nitrogen. Greater understanding of engine combustion processes was gained through testing and computer modeling. 


\section{ELECTRIC VEHICLE BATTERIES}

The focus of the DOE Electric Vehicle Battery Research and Development Program is the cooperative effort with the domestic automobile, electric utility, and battery industries through the United States Advanced Battery Consortium (USABC). The first phase of the USABC Program has been completed and the choice of battery technologies has been narrowed down to the most promising mid-term and long-term battery types. A cooperative agreement was signed for a second phase to extend the program to 2000. Exploratory research was also performed through contracts with battery manufacturers and grants to universities to pursue new battery technologies and to develop improved materials and components in support of the USABC Program.

\section{FUEL CELL SYSTEMS}

In addition to continued development of fuel cell stacks, significant progress has been made on developing on-board hydrogen storage systems and on-board fuel processing systems to generate hydrogen from conventional and alternative liquid fuels. Testing was performed on fuel cell components and prototype fuel cell systems in conjunction with fuel cell developers and domestic automobile manufacturers. Progress in each of the major systems contracts included: the selection of two subcontracts under the Ford program to develop automotive scale, direct hydrogen fuel cell systems; the development of a low-cost, full-scale, catalytic combustor under the General Motors program and the development of low-cost, lightweight bipolar plates by AlliedSignal/Chrysler. Progress was also made in development of high-pressure gaseous on-board hydrogen storage systems and on-board fuel processing systems capable of reforming a variety of fuels into hydrogen.

\section{AUTOMOTIVE MATERIALS}

The two areas of focus in the advanced automotive materials area were (1) lightweight materials for body, chassis, and engine components to reduce overall vehicle weight, and (2) propulsion system materials to improve engine performance capabilities. Improvements were made in casting of light metals, forming of aluminum sheet, adhesive bonding, powder metallurgy, and development of polymermatrix composites. Advances in propulsion system materials included demonstration of gelcasting techniques, improvements in silicon nitride mechanical properties, and development of testing methods and measurement techniques.

\section{ALTERNATIVE FUELS}

Progress ranged from component research and development, to address major problem areas in the utilization of specific alternative fuels, to the development and demonstration of alternative fuel vehicles. Strides were made to overcome the difficulties in starting alcohol-fueled engines in cold weather, as well as problems associated with combustion of hydrogen fuel. Several alternative fuel vehicles were built and demonstrated, including a compressed natural gas vehicle, an ethanol ultra-low-emission vehicle, and a propane-fueled ultra-low-emission vehicle.

\section{FUTURE PLANS}

In order to meet its long-range goals, OAAT has developed a comprehensive implementation strategy to ensure that the Nation's resources are applied in the most effective manner. Key elements of this strategy are formulated in the 5-Year $R \& D$ Plan for the Office of Advanced Automotive Technologies Energy Efficient Technologies for the 21 st Century Vehicles. This plan calls for government/industry coordination, and involves the automotive industry, national laboratories, universities, other government agencies, trade organizations, and consulting and research firms, as well as partnerships and coalitions among these organizations. The work is implemented through a range of mechanisms, including costshared contracts, cooperative agreements, grants, memoranda of understanding, interagency agreements, 
and direct field authorization and work assignments. The plan describes the important relationship of OAAT programs to the PNGV, and a primary aspect of future implementation is participation in the PNGV. The effectiveness of these endeavors is ensured through realistic project definition, cooperative and complementary tasks, and extensive coordination with other organizations doing similar work.

The OAAT strategy is directed toward development and validation of energy-efficient, petroleum-based propulsion technologies, electric and hybrid-electric vehicle technologies, and alternative fuel technologies that comply with projected emission control statutes. The U.S. is not alone in striving to meet the ambitious goals of reducing dependence of the transportation sector on petroleum, and reducing vehicle emissions. Many foreign countries are forging ahead with programs to develop these technologies. The global nature of this effort speaks not only for the urgency of these needs, but also for the opportunities for our Nation's automotive industry to be in the forefront of this highly competitive industry. 


\subsection{RECOMMENDATIONS}

Based on the Department's assessment of progress toward the overall Automotive Technology

Development Program goals, recommendations have been included in the annual budget request and can be found in the Fiscal Year 1998 Congressional Budget Request Volume 4. 


\section{APPENDIX A \\ LEGISLATIVE REQUIREMENTS AND COMPLIANCE}

This Appendix presents information on compliance with the requirements of Title III of the Automotive Propulsion Research and Development Act of 1978 (Public Law 95-238) as described in the Preface. These requirements apply to the Advanced Heat Engines activities conducted by the Office of Advanced Automotive Technologies (OAAT).

\section{ADVANCED HEAT ENGINES PROGRAM FUNDING OBLIGATIONS}

In compliance with subsection 310(a)(3) of Title III of Public Law 95-238, the funding obligations for the Advanced Heat Engines Program were as shown below:

- 2 contracts for a total of $\$ 5.869$ million

- 6 university grants totaling $\$ 0.730$ million

- 1 interagency agreement (NASA) for $\$ 0.50$ million

- 3 laboratory task assignments totaling $\$ 0.735$ million

- 12 CRADAs totaling $\$ 3.380$ million.

Funding for the Advanced Heat Engines Program in fiscal year 1996 totaled \$11.2 million. Approximately $\$ 5.8$ million is funded from the Vehicle Systems Program, and the remaining $\$ 5.35$ million is funded from the Advanced Heat Engines Program.

\section{CERTIFICATION OF NEW RESEARCH AND DEVELOPMENT CONTRACTS, GRANTS, AND COOPERATIVE AGREEMENTS}

Section 304(f)(1) of Title III of Public Law 95-238 requires that all new research and development for advanced automotive propulsion system alternatives to existing internal combustion engines funded under the authority of the Act supplement, but neither supplant nor duplicate, the automotive research and development efforts of private industry. To assure compliance with this requirement, section $304(f)(2)$ requires the Secretary to issue regulations specifying the procedures, standards, and criteria to be used in the administration of the Office of Advanced Automotive Technologies Advanced Heat Engines Program to ensure that each new research and development contract, grant, or cooperative agreement for a Department of Energy project or for a project of another Federal agency (such as NASA) funded under the Act meets the statutory requirement. These regulations are set forth in 10 Code of Federal Regulations (CFR) Part 473. Section 304(f)(4) requires that the annual report include a detailed discussion of how the research and development contracts, grants, and cooperative agreements funded pursuant to the Act satisfy the requirement expressed in section 304(f). A discussion of the Department of Energy's efforts in compliance with section 304 follows.

To be considered for a contract or to receive financial assistance under the Act, the regulations require the applicant to submit, in addition to the routine information required in a procurement or financial assistance initiative, specific information justifying certification by the manager of the proposed project under 10 CFR 473.24

Upon receipt of an application, whether unsolicited or in response to a solicitation, the manager causes a notice to be published in the Commerce Business Daily describing the nature of the proposal and inviting any interested person who believes that the proposal does not meet the criteria of 10 CFR 473.30, implementing section 304(f)(1), to submit a written objection. Following the close of the objection period, the manager makes an initial determination of compliance with the Act and submits appropriate 
proposals to the interagency review panel. The panel consists of representatives from the Department of Energy, NASA, the Environmental Protection Agency, and the National Highway Traffic Safety Administration who are knowledgeable in the areas of industry and Government research and development on automotive propulsion. Following the appropriate review and consideration of each proposal, the panel makes a recommendation to the manager, who then makes the final determination of compliance and, if the determination is affirmative, certifies the proposal pursuant to 10 CFR 473.24.

These procedures were followed for each advanced automotive propulsion system procurement. These procurements were entered into, made, or formally approved and initiated after February 25,1978 , the date of the Act's enactment. No written objections to any of the proposals summarized in the Commerce Business Daily were received, and certification was recommended in each case by the interagency review panel.

As a result of adherence to the procedures described above, the requirements of section $304(f)(1)$ of the Act have been satisfied. 


\section{APPENDIX B PUBLICATIONS LIST}

This Appendix contains a list of publications based on the work performed in fiscal year 1996 under the programs sponsored by the Office of Advanced Automotive Technologies. Also included is work performed in the prior fiscal year, but published in fiscal year 1996. It includes reports, presentations, and articles that describe the activities as well as the technical background of this program. Additional publications lists can be found in the Office of Transportation Technologies' Annual Reports to Congress for previous fiscal years.

\subsection{VEHICLE SYSTEMS}

\section{HYBRID VEHICLES}

Andrew, Michael G. and Ronald C. Miles, Johnson Controls Battery Group, Inc., Ronald I. Sims, Ford Motor Company, "Thin Metal Film Battery Technology," Volume II - U.S. Department of Energy, Annual Automotive Technology Development Customers' Coordination Meeting, Dearborn, MI, October 28 - November 1, 1996.

Baer, Jose, Jerry McAlwee, and David Swan, AeroVironment, Inc., "A SmartGuard Battery Management System for Series Hybrid Vehicles," Volume II - U.S. Department of Energy, Annual Automotive Technology Development Customers ' Coordination Meeting, Dearborn, MI, October 28 November 1, 1996.

Brown, Tim, Joachim Nell, and Charlotte A. Paul, ITT Automotive North America, "Advanced Braking Technology for Hybrid Electric Vehicles," Volume II - U.S. Department of Energy, Annual Automotive Technology Development Customers' Coordination Meeting, Dearborn, MI, October 28 - November 1, 1996.

Casale, Thomas J. and James G. Kalivas, OPTIMA Advanced Technologies, Inc., "High-Power LeadAcid Battery for Series Hybrid Vehicles," Volume II - U.S. Department of Energy, Annual Automotive Technology Development Customers' Coordination Meeting, Dearborn, MI, October 28 - November 1, 1996.

Cuddy, M.R. and K.B. Wipke, National Renewable Energy Laboratory, "ADVISOR, Advanced Vehicle Simulator, New Opportunities for Screening Advanced Components," Volume II - U.S. Department of Energy, Annual Automotive Technology Development Customers ' Coordination Meeting, Dearborn, MI, October 28 - November 1, 1996.

Cuddy, M.R. and K.B. Wipke, "Analysis of the Fuel Economy Benefits of Drivetrain Hybridization," SAE Paper 970289, 1997 SAE International Congress and Exposition, Detroit, MI, February 2427, 1997.

Dunn, Michael T., Ford Motor Company, "Hardware-in-the-Loop'(HITL) Laboratory," Volume II - U.S. Department of Energy, Annual Automotive Technology Development Customers ' Coordination Meeting, Dearborn, MI, October 28 - November 1, 1996.

Ford Motor Company, "FORD/DOE/UQM Flywheel Program," Volume II - U.S. Department of Energy, Annual Automotive Technology Development Customers ' Coordination Meeting, Dearborn, MI, October 28 - November 1, 1996. 
Ford Motor Company, "Gas Turbine Turbogenerators for Hybrid Electric Vehicles (HEVs)," Volume II U.S. Department of Energy, Annual Automotive Technology Development Customers' Coordination Meeting, Dearborn, MI, October 28 - November 1, 1996.

Gerstner, Mary, AlliedSignal, "AlliedSignal Turbogenerator for Hybrid Electric Vehicles," Volume II U.S. Department of Energy, Annual Automotive Technology Development Customers' Coordination Meeting, Dearborn, MI, October 28 - November 1, 1996.

Johannson, Lennart, Stirling Thermal Motors, Inc., "A Stirling Power Unit for Series Hybrid Vehicles," Volume II - U.S. Department of Energy, Annual Automotive Technology Development Customers' Coordination Meeting, Dearborn, MI, October 28 - November 1, 1996.

Kost, Robert A., "Hybrid Propulsion Systems Development," Volume I - U.S. Department of Energy, Annual Automotive Technology Development Customers ' Coordination Meeting, Dearborn, MI, October 28 - November 1, 1996.

Mendler, C., "The Technological Opportunities of Hybrid Electric Vehicles," SAE Paper 961717, 1996 SAE Future Transportation Technology Conference, Vancouver, Canada, August 1996.

Oswald, Lawrence J. and Gerald D. Skellenger, "General Motors Hybrid Propulsion Systems Development Program," Volume I - U.S. Department of Energy, Annual Automotive Technology Development Customers' Coordination Meeting, Dearborn, MI, October 28 - November 1, 1996.

Rajashekara, Kaushik, Delco Propulsion Systems, "Advanced Hybrid Electric Vehicle Technology," Volume II - U.S. Department of Energy, Annual Automotive Technology Development Customers' Coordination Meeting, Dearborn, MI, October 28 - November 1, 1996.

Sharma, Naresh, AeroVironment, Inc.; Kaushik Ragashekara, Michael Lowry, and John Morgante, Delco Propulsion Systems; Balarama Murty, General Motors; "An Electric Drive System for Series Hybrid Vehicles," Volume II - U.S. Department of Energy, Annual Automotive Technology Development Customers' Coordination Meeting, Dearborn, MI, October 28 - November 1, 1996.

Speth, Stephan J., Chrysler Vehicle Engineering, Liberty \& Technical Affairs, "Chrysler Hybrid Propulsion Systems Development Program," Volume I - U.S. Department of Energy, Annual Automotive Technology Development Customers ' Coordination Meeting, Dearborn, MI, October 28 - November 1, 1996.

Stokes, Gary P. and Michael A. Tamor, Ford Motor Company, "Ford Hybrid Propulsion Systems Development Program," Volume I - U.S. Department of Energy, Annual Automotive Technology Development Customers' Coordination Meeting, Dearborn, MI, October 28 - November, 1, 1996.

TRA-TCAE Turbine Engines, Allegheny Teledyne, "Teledyne Ryan Aeronautical TCAE Turbine Engines," Volume II - U.S. Department of Energy, Annual Automotive Technology Development Customers ' Coordination Meeting, Dearborn, MI, October 28 - November 1, 1996.

Wipke, K.B., "Reducing VMTs Through Transit On-Demand with GPS and Satellite Communications," IEEE Northcom/96 Conference, Seattle, WA, 1996; published in the IEEE Technical Applications Conference Record.

Wipke, K.B. and M.R. Cuddy, "Using an Advanced Vehicle Simulator (ADVISOR) to Guide Hybrid Vehicle Propulsion Development," NESEA Sustainable Transportation Conference, S/EV96, New York, NY, September 16-18, 1996. 


\section{HIGH-POWER ENERGY STORAGE}

Chagnon, Guy, SAFT America Inc., "Lithium-Ion Batteries for PNGV Applications," Volume II - U.S. Department of Energy, Annual Automotive Technology Development Customers' Coordination Meeting, Dearborn, MI, October 28 - November 1, 1996.

Farahmandi, C.J., Maxwell Technologies, Inc., "Electrochemical Capacitor Technology for Automotive Applications," Volume II - U.S. Department of Energy, Annual Automotive Technology

Development Customers' Coordination Meeting, Dearborn, MI, October 28 - November 1, 1996.

Haskins, H., Ford Motor Company, "Energy Storage Requirements for Hybrid Systems," Volume I - U.S. Department of Energy, Annual Automotive Technology Development Customers ' Coordination Meeting, Dearborn, MI, October 28 - November 1, 1996.

Johnson, Gary W., Troy W. Barbee, Jr., and Dennis W. O'Brien, Lawrence Livermore National Laboratory, "Nanostructure, Multilayer Capacitors for Power Electronic Applications," Volume II - U.S. Department of Energy, Annual Automotive Technology Development Customers' Coordination Meeting, Dearborn, MI, October 28 - November 1, 1996.

O’Kain, D., Oak Ridge National Laboratory, "Computer Models for Predicting Flywheel System Failure Modes and Rotor Crash Loads," Volume II - U.S. Department of Energy, Annual Automotive Technology Development Customers ' Coordination Meeting, Dearborn, MI, October 28 November 1, 1996.

Sutula, R.A., U.S. Department of Energy, "The Department of Energy's High-Power Energy Storage Programs," Volume I - U.S. Department of Energy, Annual Automotive Technology Development Customers ' Coordination Meeting, Dearborn, MI, October 28 - November 1, 1996.

\section{POWER ELECTRONICS AND ELECTRIC MACHINES}

Adams, D.J., Oak Ridge National Laboratory, "Power Electronics and Machine Challenges and Opportunities," Volume I - U.S. Department of Energy, Annual Automotive Technology

Development Customers ' Coordination Meeting, Dearborn, MI, October 28 - November 1, 1996.

Ashtiani, C., Chrysler Corporation, "Power Electronics Automotive Applications," Volume I - U.S. Department of Energy, Annual Automotive Technology Development Customers ' Coordination Meeting, Dearborn, MI, October 28 - November 1, 1996.

Hamilton, D.B., U.S. Department of Energy, "Electric Propulsion Power System - Overview," Volume 1 U.S. Department of Energy, Annual Automotive Technology Development Customers'

Coordination Meeting, Dearborn, MI, October 28 - November 1, 1996.

\section{ADVANCED VEHICLE COMPETITIONS}

Duoba, M. and R. Larsen, "HEV Dynamometer Testing with State-of-Charge Corrections in the 1995 HEV Challenge," SAE Paper 960740, SAE International Congress and Exposition, Detroit, MI, February 1996.

Duoba, M., R. Larsen, and N. LeBlanc, "Design Diversity of HEVs with Example Vehicles from HEV Competitions," SAE Paper 960736, SAE International Congress and Exposition, Detroit, MI, February 1996. 
Launey, Shelley, U.S. Department of Energy, and Robert Larsen, Argonne National Laboratory, "Advanced Vehicle Research Competitions - Developing and Integrating Future Transportation Technologies Today," Volume I - U.S. Department of Energy, Annual Automotive Technology Development Customers' Coordination Meeting, Dearborn, MI, October 28, 1996.

LeBlanc, N., M. Duoba, and R. Larsen, "The 1995 HEV Challenge: Results and Technology Summary," SAE Paper 960741, SAE International Congress and Exposition, Detroit, MI, February 1996.

Sluder, S., M. Duoba, and R. Larsen, “1997 Hybrid Electric Vehicle Specifications,” ANL/ESD/TM-136, Argonne National Laboratory, Argonne, IL, 1996.

\subsection{ADVANCED HEAT ENGINES}

\section{GAS TURBINE HYBRID POWER UNIT}

Belaire, Richard C., Ford Research Laboratory, "Turbogenerator for a Series Hybrid Vehicle," Presentation Without Publication, The 41st ASME International Gas Turbine \& Aeroengine Congress, Exposition and Users Symposium, Birmingham, UK, June 10-13, 1996.

Berenyi, S.G. and J. Richards, Allison Engine Company, "Hybrid Vehicle Turbine Engine Technology Support (HVTETS)," Volume II - U.S. Department of Energy, Annual Automotive Technology Development Customers ' Coordination Meeting, Dearborn, MI, October 28 - November 1, 1996.

Davis, Leonard C. and Anthony V. Jackman, Allison Engine Company, "Some Significant Highlights in Allison Regenerator Development," 96-GT-503, The 41st ASME International Gas Turbine \& Aeroengine Congress, Exposition and Users Symposium, Birmingham, UK, June 10-13, 1996.

Easley, M.L., AlliedSignal Engines, "Turbine Technologies: Ceramic Turbine Engine Demonstration Project," Volume II - U.S. Department of Energy, Annual Automotive Technology Development Customers' Coordination Meeting, Dearborn, MI, October 28 - November 1, 1996.

Heathco, Craig, Allison Engine Co., "Optimizing a Turbine APU Configuration for Hybrid Use," Presentation Without Publication, The 41st ASME International Gas Turbine \& Aeroengine Congress, Exposition and Users Symposium, Birmingham, UK, June 10-13, 1996.

Hughes, Les, Volvo Aero Turbines, "HSG 100 - A Turbo-Generator Engine for Use in Hybrid Vehicles," Presentation Without Publication, The 41st ASME International Gas Turbine \& Aeroengine Congress, Exposition and Users Symposium, Birmingham, UK, June 10-13, 1996.

Janosik, Lesley A. and Stephen F. Duffy, NASA Lewis Research Center, "A Viscoplastic Constitutive Theory for Monolithic Ceramics - I," 96-GT-368, The 41st ASME International Gas Turbine \& Aeroengine Congress, Exposition and Users Symposium, Birmingham, UK, June 10-13, 1996.

Pollinger, John P., AlliedSignal Aerospace, "Progress in Fabrication of Silicon Nitride Structural Components for Turbomachinery Applications," 96-GT-347, The 41st ASME International Gas Turbine \& Aeroengine Congress, Exposition and Users Symposium, Birmingham, UK, June 10$13,1996$.

Powers, Lynn M., Cleveland State University, Osama M. Jadaan, University of Wisconsin-Platteville, and John P. Gyekenyesi, NASA-Lewis Research Center, "Creep Life of Ceramic Components Using a Finite Element Based Integrated Design Program (CARES/CREEP)," 96-GT-369, The 41st ASME International Gas Turbine \& Aeroengine Congress, Exposition and Users Symposium, Birmingham, UK, June 10-13, 1996. 
Rettler, M.W., M.L. Easley, and J.R. Smyth, AlliedSignal Aerospace Company, "Ceramic Gas Turbine Technology Development," 96-GT-367, The 41st ASME International Gas Turbine \& Aeroengine Congress, Exposition and Users Symposium, Birmingham, UK, June 10-13, 1996.

Sebestyen, Thomas M., U.S. Department of Energy, "Hybrid Vehicle Turbine Engine Supporting Technologies R\&D Program and Plans," Volume I - U.S. Department of Energy, Annual Automotive Technology Development Customers' Coordination Meeting, Dearborn, MI, October 28 - November 1, 1996.

Skiellenger, Gerald D., Gas Turbine Technical Team, "Hybrid Vehicle Turbine Engine Requirements, Main Technical Barriers and R\&D Needs," Volume I - U.S. Department of Energy, Annual Automotive Technology Development Customers' Coordination Meeting, Dearborn, MI, October $29,1996$.

\section{ADVANCED AUTOMOTIVE HEAT ENGINES}

Courtright, E.L. and G.L. McVay, Pacific Northwest National Laboratory, “AAPET/ESST Related Efficiency \& Emissions Project Summary," Volume II - U.S. Department of Energy, Annual Automotive Technology Development Customers' Coordination Meeting, Dearborn, MI, October 28 - November 1, 1996.

Duleep, K.D., Energy and Environmental Analysis, Inc., "Engine Technologies to Improve Fuel Economy," Volume I - U.S. Department of Energy, Annual Automotive Technology Development Customers' Coordination Meeting, Dearborn, MI, October 28 - November 1, 1996.

Foulkes, D.M., Ford Motor Company, “Advanced Hybrid Vehicle CIDI Engine Requirements, Main Technical Barriers and R\&D Needs," Volume I - U.S. Department of Energy, Annual Automotive Technology Development Customers' Coordination Meeting, Dearborn, MI, October 28 November 1, 1996.

Miree, T.J., Ford Motor Company, "Conventional Spark Ignition Engine Requirements, Main Technical Barriers and R\&D Needs," Volume I - U.S. Department of Energy, Annual Automotive Technology Development Customers' Coordination Meeting, Dearborn, MI, October 28 November 1, 1996.

Sorensen, S.M., Idaho National Engineering Laboratory, "Advanced Automotive Piston Engines Manufacturing, Efficiency and Emissions R\&D," Volume II - U.S. Department of Energy, Annual Automotive Technology Development Customers' Coordination Meeting, Dearborn, MI, October 28 - November 1, 1996.

Sutton, Patrick L., U.S. Department of Energy, “Advanced Automotive Piston Engine and Combustion and Emissions R\&D Program and Plans," Volume I - U.S. Department of Energy, Annual Automotive Technology Development Customers' Coordination Meeting, Dearborn, MI, October 28 - November 1, 1996.

\section{COMBUSTION EFFICIENCY AND EMISSIONS}

Carling, Robert W., Sandia National Laboratories, "Advanced Automotive Piston Engines-Combustion R\&D," Volume II - U.S. Department of Energy, Annual Automotive Technology Development Customers' Coordination Meeting, Dearborn, MI, October 28 - November 1, 1996. 
Carling, Robert W., Sandia National Laboratories, "Combustion Efficiency and Emissions R\&D," Volume II - U.S. Department of Energy, Annual Automotive Technology Development Customers' Coordination Meeting, Dearborn, MI, October 28 - November 1, 1996.

Dec, J.E. and E. Coy, "OH Radical Imaging in a DI Diesel Engine and the Structure of the Early Diffusion Flame," SAE Paper 960831, 1996.

DeMurry, T.L., Pennsylvania State University, Thesis, "Investigation into the Role of Crevice Volumes in the Formation of Unburned Hydrocarbon Emissions in Spark Ignition Engines," December 1995.

Felton, P.G., D.C. Kyritsis, S.K. Fulcher, "LIF Visualization of Liquid Fuel in the Intake Manifold During Cold Start," SAE Paper 952464, 1995.

Fulcher, S.K., Princeton University, Thesis No. 2019T, "The Effects of Fuel Atomization, Vaporization and Mixing on the Cold Start Emissions of a Contemporary SI Engine with Intake Manifold Injection," November 1996.

Fulcher, S.K., B.F. Ghandhi, and F.V. Bracco, "The Effects of Fuel Atomization, Vaporization and Mixing on the Cold Start UHC Emissions of a SI Engine with Intake Manifold Injection," SAE Paper 952482, 1995.

Geiger, G.L., Pennsylvania State University, Thesis, "An Investigation of Hydrocarbon Emissions Formation in a Single Cylinder Spark Ignition Engine Using Rapid Gas Sampling and Gas Chromatography," August 1996.

Ghandhi, J.B. and P.G. Felton, "On the Fluorescent Behavior of Ketones at High Temperatures," Experiments in Fluids, 1996, Vol. 21, pp. 143-144.

Kayes, D. and S. Hochgreb, "Development of a Time and Space Resolved Sampling Probe Diagnostic for Engine Exhaust Hydrocarbons," SAE Paper 961002, 1996.

Lee, C.F. and B.F. Gajdeczko, "Quantitative Exciplex Measurements of Vapor Concentration in Air Assisted Sprays," ILASS Americas 96, 9th Annual Conference on Liquid Atomization and Spray Systems, San Francisco, CA, May 1996.

Miles, P.C., "Geometry of the Fringe Field Formed in the Intersection of Two Gaussian Beams," Optical Society of America, 1996, Vol. 35, No. 30.

Miles, P.C. and M. Dilligan, "Quantitative In-Cylinder Fluid Composition Measurements Using Broad and Spontaneous Raman Scattering," SAE Paper 960828, 1996.

Miles, P.C. and P.O. Witze, "Evaluation of the Gaussian Beam Model for Prediction of LDV Fringe Field," Proceedings of the Eighth International Symposium on Applications for Laser Techniques to Fluid Mechanics, Lisbon, Portugal, July 1996.

O’Rourke, P., “A Particle Numerical Model for Wall Film Dynamics in Port Injected Engines,” SAE Paper 961961, 1996.

Pan, G., Princeton University, Thesis No. 2064T, "A Study of the Influence of Fuel Additives on Atomization and Evaporation of Diesel Fuels," June 1996. 
Sekar, Raj and Ramesh Poola, Argonne National Laboratory, "Variable Oxygen- or Nitrogen-Enriched Air System for Combustion Engines," Volume II - U.S. Department of Energy, Annual Automotive Technology Development Customers ' Coordination Meeting, Dearborn, MI, October 28 - November 1, 1996.

Whelan, D.E., P.L. Kelly-Zion, C.F. Lee, R.P. Lucht, J.E. Peters, and R.A. White, "Preliminary Study of Back Flow Atomization in the Intake Port of Spark Ignition Engines," 9th Annual Conference on Liquid Atomization and Spray Systems, San Francisco, CA, 1996.

Witze, P.O., R.M. Green, "LIF Visualization of Liquid Fuel in the Cylinder of a Spark Ignition Engine," Proceedings of the Eighth International Symposium on Applications of Laser Techniques to Fluid Mechanics, Lisbon, Portugal, July 1996.

Yuen, L.S., J.E. Peters, and R.P. Lucht, "Pressure Dependence of Laser Induced Fluorescence from Acetone," Proceedings of the Central States Section Meeting of the Combustion Institute, St. Louis, MO, 1996.

\subsection{ELECTRIC VEHICLE BATTERIES}

\section{UNITED STATES ADVANCED BATTERY CONSORTIUM}

Donnelly, C.A., 3M, "Lithium Polymer Batteries for Electric and Hybrid Vehicles," Volume II - U.S. Department of Energy, Annual Automotive Technology Development Customers' Coordination Meeting, Dearborn, MI, October 28 - November 1, 1996.

Duong, T., U.S. Department of Energy, "Procedures for Testing of Electric Vehicle Batteries Under USABC," Volume I - U.S. Department of Energy, Annual Automotive Technology Development Customers' Coordination Meeting, Dearborn, MI, October 28 - November 1, 1996.

Heitner, K.L., U.S. Department of Energy, "Electric Vehicle Energy Storage Requirements," Volume I U.S. Department of Energy, Annual Automotive Technology Development Customers" Coordination Meeting, Dearborn, MI, October 28 - November 1, 1996.

Hunt, Gary L. and Timothy C. Murphy, Idaho National Engineering Laboratory, "Measuring Peak Power on Electric Vehicle Batteries," Volume II - U.S. Department of Energy, Annual Automotive Technology Development Customers' Coordination Meeting, Dearborn, MI, October 28 November 1, 1996.

Kinoshita, Kim, Lawrence Berkeley National Laboratory, "Advanced Battery Research at Lawrence Berkeley National Laboratory," Volume II - U.S. Department of Energy, Annual Automotive Technology Development Customers' Coordination Meeting, Dearborn, MI, October 28 November 1, 1996.

McBreen, James, S. Mukerjee, and X.Q. Yang, Brookhaven National Laboratory, "Battery Materials: Structure and Characterization," Volume II - U.S. Department of Energy, Annual Automotive Technology Development Customers' Coordination Meeting, Dearborn, MI, October 28 November 1, 1996.

Landgrebe, A.R. and J. Milliken, U.S. Department of Energy, "Exploratory Technology Research in Support of the U.S. Department of Energy Electric and Hybrid Vehicle Program," Volume I U.S. Department of Energy, Annual Automotive Technology Development Customers' Coordination Meeting, Dearborn, MI, October 28 - November 1, 1996. 
Rauhe, Bruce, Southern Company Services, Inc.; P. Gifford and V. Hellmann, GM Ovonic, L.L.C.; "The GM Ovonic Nickel Metal Hydride Electric Vehicle Battery," Volume II - U.S. Department of Energy, Annual Automotive Technology Development Customers' Coordination Meeting, Dearborn, MI, October 28 - November 1, 1996.

Sastry, Ann Marie, Xin Cheng, Steven B. Choi, Linda X. Huang, and Neil V. Shah, The University of Michigan, "Microstructural Modeling of Highly Porous Nickel Electrode Materials," Volume II U.S. Department of Energy, Annual Automotive Technology Development Customers' Coordination Meeting, Dearborn, MI, October 28 - November 1, 1996.

Shank, W.H., Ford Motor Company, "United States Advanced Battery Consortium Progress Report," Volume I - U.S. Department of Energy, Annual Automotive Technology Development Customers' Coordination Meeting, Dearborn, MI, October 28 - November 1, 1996.

Tartemella, T., Chrysler Corp., "The SAFT Nickel Metal Hydride Electric Vehicle Battery," Volume II U.S. Department of Energy, Annual Automotive Technology Development Customers' Coordination Meeting, Dearborn, MI, October 28 - November 1, 1996.

\section{EXPLORATORY TECHNOLOGY RESEARCH}

\section{Department of Energy}

Adams, W.A., B. Scrosati, and A.R. Landgrebe, eds., "Exploratory Research and Development of Batteries for Electric and Hybrid Vehicles," Proceedings Volume PV 96-14, The Electrochemical Society, Inc., Pennington, NJ, 1996.

Landgrebe, A.R. and Weinstock, E., "Commercialization of Lithium Rechargeable Batteries," Proceedings of Symposium on Exploratory Research and Development of Batteries for Electric Vehicles, Volume 14-96, The Electrochemical Society, Inc., Pennington, NJ, 1996.

Milliken, J. and A.R. Landgrebe, "Exploratory Technology Research in Support of the U.S. Department of Energy Electric and Hybrid Vehicle Program," The 13th International Electric Vehicle Symposium and Exposition, Osaka, Japan, 1996.

\section{Brookhaven National Laboratory}

Liu, K-C. and M.A. Anderson, "Porous Nickel Oxide Films for Electrochemical Capacitors," Mat. Res. Soc. Symp. Proc. 393, 427, 1995.

McBreen, J., "In Situ Synchrotron Techniques in Electrochemistry," Physical Electrochemistry: Principles, Methods and Applications, I. Rubenstein, ed., Marcel Dekker, New York, 1995, pp. 339-391.

McBreen, J., "X-Ray Absorption Spectroscopic Studies on Battery Active Materials," Handbook of Solid State Batteries and Capacitors, M.Z.A. Munshi, ed., World Scientific Publishing Co., Singapore, 1995, pp. 57-78.

Pandya, K.I., A.E. Russell, J. McBreen, and W.E. O'Grady, "EXAFS Investigations of Zn(II) in Concentrated Aqueous Hydroxide Solutions," J. Phys. Chem. 99, 11967, 1995. 


\section{Idaho National Engineering Laboratory}

Burke, A.F., "Prospects for Ultracapacitors in Electric and Hybrid Vehicles," Proceedings of the Eleventh Annual Battery Conference on Applications and Advances, Long Beach, CA, January 9-12, 1996.

\section{Lawrence Berkeley National Laboratory}

Anders, S., A. Anders, I. Brown, F. Kong, and F. McLarnon, "Surface Modification of Nickel Battery Electrodes by Cobalt Plasma Immersion Ion Implantation and Deposition," Surface \& Coatings Technology, 85, 75, 1995.

Battaglia, V. and J. Newman, "Modeling of a Growing Oxide Film: The Iron/Iron Oxide System," $J$. Electrochem. Soc. 142, 1323, 1995.

Chen, Y. and J.W. Evans, "Thermal Analysis of Lithium-Ion Batteries," J. Electrochem. Soc., November 1995.

Doeff, M.M., L. Ding, and L.C. De Jonghe, "Electrochemical Characterization of Orthorhombic NaxMnO2 for Alkali Metal Polymer Batteries," Mat. Res. Soc. Proc. 393, 107, 1995.

Doeff, M.M., S.J. Visco, Y. Ma, M. Peng, L. Ding, and L.C. De Jonghe, "Thin Film Solid State Sodium Batteries for Electric Vehicles," Electrochimica Acta 40, 2205, 1995.

Doyle, M., T.F. Fuller, and J. Newman, "Theoretical Modeling of Battery Systems," D.A. Scherson, ed., Proceedings of the Symposium on the Science of Advanced Batteries, The Electrochemical Society, Inc., Pennington, NJ, 1995, pp. 152-163.

Doyle, M. and J. Newman, "Analysis of Transference Number Measurements Based on the Potentiostatic Polarization of Solid Polymer Electrolytes," J. Electrochem. Soc. 142, 3465, 1995.

Doyle, M. and J. Newman, "Modeling the Performance of Rechargeable Lithium-Based Cells: Design Correlations for Limiting Cases," J. Power Sources 54, 46-51, 1995.

Doyle, M. and J. Newman, "The Use of Mathematical Modeling in the Design of Lithium/Polymer Battery Systems," Electrochimica Acta 40, 2191, 1995.

Doyle, M., J. Reimers, and J. Newman, "A Quick Method of Measuring the Capacity versus Discharge Rate for a Dual Lithium Ion Insertion Cell Undergoing Cycling," J. Power Sources 52, 211, 1995.

Eames, D.J. and J. Newman, "Electrochemical Conversion of Anhydrous $\mathrm{HCl}$ to $\mathrm{Cl} 2 \mathrm{Using}$ a Solid-Polymer-electrolysis Cell," J. Electrochem. Soc. 142, 3619, 1995.

Fuller, T.F. and J. Newman, "Metal Hydride Electrode," R.E. White, J. O'M. Bockris, and B.E. Conway, eds., Modern Aspects of Electrochemistry, No. 27, 359, 1995.

Gasteiger, H., N. Markovic, and P. Ross, "The Electrooxidation of $\mathrm{CO}$ and $\mathrm{H} 2 / \mathrm{CO}$ Mixtures on a Well-Characterized Pt3Sn Electrode Surface," J. Phys. Chem. 99, 8945, 1995.

Gasteiger, H., N. Markovic, and P. Ross, "Hydrogen and Carbon Monoxide Electrooxidation on Well-Characterized Pt, Ru, and Pt-Ru; Part I. Rotating Disk Electrode Studies of the Pure Gases Including Temperature Effects," J. Phys. Chem. 99, 8290, 1995. 
Gasteiger, H., N. Markovic, and P. Ross, "Hydrogen and Carbon Monoxide Electrooxidation on Well-Characterized Pt, Ru, and Pt-Ru; Part II. Rotating Disk Electrode Studies of $\mathrm{H} 2 / \mathrm{CO}$ Mixtures at $62^{\circ} \mathrm{C}, " J$. Phys. Chem. 99, 8290, 1995.

Kinoshita, K., J. Bonevich, X. Song, and T.D. Tran, "Transmission Electron Microscopy of Carbons for Lithium Intercalation," Proceedings of the 10th International Conference on Solid State Ionics, Singapore, December 3-8, 1995, B. Chowdari, ed., Elsevier Science B.V., Amsterdam, The Netherlands.

Ma, Y.P., M. Doyle, T.F. Fuller, M.M. Doeff, L.C. De Jonghe, and J. Newman, "The Measurement of a Complete Set of Transport Properties for a Concentrated Solid Polymer Electrolyte Solution," J. Electrochem. Soc. 142, 1859, 1995.

Markovic, N., H. Gasteiger, and P. Ross, "Oxygen Reduction on Platinum Low-Index Single Crystal Surfaces in Sulfuric Acid Solution: Rotating Ring-Pt(hkl) Disk Electrode Studies," J. Phys. Chem. 99, 3411, 1995.

Markovic, N., H. Gasteiger, P. Ross, X. Xiang, I. Villegas, and M. Weaver, "Electrooxidation Mechanisms of Methanol and Formic Acid on Pt-Ru Alloy Surfaces," Electrochimica Acta 40, 91, 1995.

Newman, J., "Optimization of Porosity and Thickness of a Battery Electrode by Means of a Reaction-Zone Model," J. Electrochem. Soc. 142, 97, 1995.

Newman, J., "Thermoelectric Effects in Electrochemical Systems," Ind. Engr. Chem. Res. 34, 3208, 1995.

Pals, C.R. and J. Newman, "Thermal Modeling of the Lithium/Polymer Battery; I. Discharge Behavior of a Single Cell," J. Electrochem. Soc. 142, 3274, 1995.

Pals, C.R. and J. Newman, "Thermal Modeling of the Lithium/Polymer Battery; II. Temperature Profiles in a Cell Stack," J. Electrochem. Soc. 142, 3274, 1995.

Plivelich, R.F., F.R. McLarnon, and E.J. Cairns, "Degradation Mechanisms of Nickel Oxide Electrodes in Zinc/Nickel Oxide Cells with Low-Zinc-Solubility Electrolytes," J. Appl. Electrochem. 25, 433, 1995.

Radmilovic, V., H. Gasteiger, and P. Ross, "Structure and Composition of a Supported Pt-Ru Electrocatalyst for Methanol Oxidation," J. Catal. 154, 98, 1995.

Rauhe, B.R., F.R. McLarnon, and E.J. Cairns, "Direct Anodic Oxidation of Methanol on Supported Platinum/Ruthenium Catalyst in Aqueous Cesium Carbonate," J. Electrochem. Soc. 142, 1073, 1995.

Ridgway, P.L., F.R. McLarnon, and E.J. Cairns, "Sodium/Phosphorous-Sulfur Cells I; Cell Performance," J. Electrochem. Soc. 143, 406, 1996.

Ridgway, P.L., F.R. McLarnon, and E.J. Cairns, "Sodium/Phosphorous-Sulfur Cells II; Phase Equilibria," J. Electrochem. Soc. 143, 412, 1996.

Ross, P. and H. Gasteiger, "Methanol Electrocatalysis by Pt Alloys and Ad-Atom Modified Pt New Materials for Fuel Cell Systems," O. Savogado, P. Roberge, and T. Veziroglu, eds., Editions de L'Ecole Polytechnique de Montreal, 1995, pp. 286-96. 
Rush, B. and J. Newman, "Periodic Behavior in the Iron/Sulfuric Acid System," J. Electrochem. Soc. $142,3770,1995$.

Song X. and K. Kinoshita, "Structural Characterization of Carbon Materials Prepared at Low Temperatures," Materials for Electrochemical Energy Storage and Conversion - Batteries, Capacitors and Fuel Cells, Materials Research Society Spring Meeting, San Francisco, CA, April 1995, D. Doughty, B. Vyas, J. Huff, and T. Takamura, eds., Materials Research Society, Pittsburgh, PA.

Tiedemann, W. and J. Newman, "Temperature Rise in a Battery Module with Constant Heat Generation," J. Electrochem. Soc. 142, 1054, 1995.

Visco, S.J. and L.C. De Jonghe, "Advanced Batteries Based on Organosulfur Redox Chemistry," Handbook of Solid State Batteries and Capacitors, M.Z.A. Munshi, ed., World Scientific, Singapore, 515, 1995.

Wang, M.-H. and J. Newman, "The Electrical Conductivity of Sodium Polysulfide Melts," J. Electrochem. Soc. 142, 761, 1995.

\section{Lawrence Livermore National Laboratory}

Tran, T.D., J.H. Feikert, S.T. Mayer, X. Song, and K. Kinoshita, "Carbonaceous Materials as Lithium Intercalation Anodes," Proceedings of the Symposium on Rechargeable Lithium and Lithium Ion (RCT) Batteries, Vol. 94-28, S. Megahed, B. Barnett, and L. Xie, eds., The Electrochemical Society, Inc., Pennington, NJ, 1995, p. 110.

Tran, T.D., J.H. Feikert, X. Song, and K. Kinoshita, "Commercial Carbonaceous Materials as Lithium Intercalation Anodes," J. Electrochem. Soc. 142, 3297, 1995.

Tran, T.D. and K. Kinoshita, "Lithium Intercalation/Deintercalation Behavior of Basal and Edge Planes of Highly Ordered Pyrolytic Graphite," J. Electroanal. Chem. 386, 221, 1995.

\section{Oak Ridge National Laboratory}

Dudney, N.J., J.B. Bates, D. Lubben, and F.X. Hart, "Thin-Film Rechargeable Lithium Batteries with Amorphous LixMn2O4 Cathodes," Thin-Film Solid Ionic Devices and Materials, J.B. Bates, ed., The Electrochemical Society, Inc., Pennington, NJ, 1995, p. 201.

\section{Northwestern University}

Lonergan, M.C., D.F. Shriver, A. Nitzan, and M.A. Ratner, "The Mechanism and Modeling of Conductivity in Polymer Electrolytes," Mat. Res. Soc. Symp. Proc. 369, 245, 1995.

Lonergan, M.C., D.F. Shriver, and M.A. Ratner, "Polymer Electrolytes: The Importance of Ion-Ion Interactions in Diffusion Dominated Behavior," Electrochimica Acta 40, 2041, 1995.

Payne, V.A., J-h. Xu, M. Forsyth, M.A. Ratner, and D.F. Shriver, "Molecular Dynamics Simulations of Ion Clustering and Conductivity in Nal/Ether Solutions; I. Effect of Ion Charge," J. Chem. Phys. $\cdot 103,8734,1995$.

Payne, V.A., J-h. Xu, M. Forsyth, M.A. Ratner, and D.F. Shriver, "Molecular Dynamics Simulations of Ion Clustering and Conductivity in Nal/Ether Solutions; II. Effect of Ion Concentration," J. Chem. Phys. 103, 8746, 1995. 


\section{State University of New York at Binghamton}

Chen, R., T. Chirayil, and M.S. Whittingham, "The Hydrothermal Synthesis of Sodium Manganese Oxide and a Lithium Vanadium Oxide," Proc. of the 12th International Symposium on Solid State Ionics, Singapore, December 1995.

Chirayil, T.G., P. Zavalij, and M.S. Whittingham, "Hydrothermal Synthesis of Vanadium Oxides," Paper No. O7.41, Materials Research Society, Boston, MA, November 29, 1995.

Guo J-D., Y.J. Li, and M.S. Whittingham, "Hydrothermal Synthesis of Electrode Materials: Pyrochlore Tungsten Trioxide WO3 Film," J. Power Sources 54, 461, 1995.

Guo J-D., P. Zavalij, and M.S. Whittingham, "Metastable Hexagonal Molybdates: Hydrothermal Preparation, Structure and Reactivity," J. Solid State Chem. 117, 323, 1995.

Janauer, G.J., A. Dobley, J-D. Guo, P. Zavalij, and M.S. Whittingham, "Hydrothermal Synthesis of Novel Tungsten and Molybdenum Oxides by Use of Surfactant Templates," Paper O7.42, Materials Research Society, Boston, MA, November 29, 1995.

Whittingham, M.S., J-D. Guo, R. Chen, T. Chirayil, G. Janauer, and P. Zavalij, "The Hydrothermal Synthesis of New Oxide Materials," Solid State Ionics 75, 257, 1995.

\section{University of Wisconsin}

Liu, K-C. and M.A. Anderson, "Porous Nickel Oxide Films for Electrochemical Capacitors," Mat. Res. Soc. Symp. Proc. 393, 427, 1995.

\section{ELECTRIC VEHICLE READINESS}

Hammel, C.J., "Advanced Battery Environmental, Health, and Safety Program," Lithium Battery Energy Storage Technology Research Association, Progress Report Meeting, Tokyo, Japan, September 24, 1996.

Hammel, C.J., "Environmental, Health, and Safety Issues of Lithium Ion Batteries," Second International Symposium on Lithium Batteries, Tokyo, Japan, September 27, 1996.

Hammel, C.J., "Executive Committee Report," ad hoc Advanced Battery Readiness Working Group Meeting, Washington, DC, March 21-22, 1996.

Hammel, C.J., Testimony, California Air Resources Board Workshop on Electric Vehicle Battery Safety, Los Angeles, CA, October 11-12, 1995.

Helton, Robert A., U.S. Department of Energy, "Electric Vehicles Load Management Issues," Electric Power Research Institute, National Electric Vehicle Infrastructure Working Council, January 31, 1996.

Vimmerstedt, L.J., "Environmental, Health, and Safety Issues of Lithium Ion Batteries," ad hoc Advanced Battery Readiness Working Group Meeting, Washington, DC, March 21-22, 1996.

Vimmerstedt, L.J.,"Environmental, Health, and Safety Issues of Lithium Ion Batteries," Lithium Battery Technical/Safety Group Meeting, San Diego, CA, February 13-14, 1996. 
Vimmerstedt, L.J. and C.J. Hammel, "Current Status of Environmental, Health, and Safety Issues of Electrochemical Capacitors for Advanced Vehicle Applications," National Renewable Energy Laboratory, Golden, CO.

\subsection{FUEL CELL SYSTEMS}

\section{SYSTEMS TECHNOLOGY DEVELOPMENT}

\section{Department of Energy}

Chalk, S.G., P.G. Patil, and S.R. Venkateswaran, "The New Generation of Vehicles: Market Opportunities for Fuel Cells," Journal of Power Sources 61, 7-13, 1996.

Davis, P.B., "DOE Automotive Fuel Cell Development Program," Volume I - U.S. Department of Energy, Annual Automotive Technology Development Customers' Coordination Meeting, Dearborn, MI, October 28 - November 1, 1996.

Davis, P.B. and D. Lee, "DOE Fuel Cells for Transportation Update," NESEA Sustainable Transportation S/EV96 Procecdings, Madison Square Garden, New. York, NY, September 16-18, 1996.

Patil, P. and J. Miller, "International Fuel Cell Activities," NESEA Sustainable Transportation Symposium on Solar and Electric Vehicles S/EV 55 Proceedings, Providence, RI, November 13$15,1995$.

Wilson, M.S., C. Zawadzinski, S. Gottesfeld, and A.R. Landgrebe, "Stationary Power Applications for Polymer Electrolyte Fuel Cells," Proceedings of the Eleventh Annual Battery Conference on Applications and Advances, January 1996.

\section{Argonne National Laboratory}

Krumpelt, M. and R. Kumar, "Overview of Fuel Cell Power Sources for Vehicles," Symposium on Electrochemical Power Sources for Electric Vehicles, AIChE Annual Meeting, Miami Beach, FL, November 12-17, 1995.

Kumar, R., "Overview of the U.S. Contribution to the Polymer Electrolyte Fuel Cell Annex," International Energy Agency's PEFC Annex VIII Workshop, KFA-Jülich, Germany, May 9-10, 1996.

\section{Los Alamos National Laboratory}

Gottesfeld, S., "Polymer Electrolyte Direct Methanol Fuel Cells: An Option for Transportation Applications," Proceedings of Intertech Conference on Commercializing Fuel Cell Vehicles, Chicago, IL, September 17-19, 1996.

\section{DOE Contractors}

\section{Arthur D. Little}

Bentley, J., "PEM Fuel Cell Systems Driving Towards a Complete Power Plant," Proceedings of Intertech Conference on Commercializing Fuel Cell Vehicles, Chicago, IL, September 17-19, 1996. 


\section{Chrysler Corporation}

Borroni-Bird, C., "Automotive Fuel Cell Requirements," Volume I - U.S. Department of Energy, Annual Automotive Technology Development Customers' Coordination Meeting, Dearborn, MI, October 28 - November 1, 1996.

Borroni-Bird, C., "Is There a Fuel Cell in the Automobile's Future?," Proceedings of Intertech Conference on Commercializing Fuel Cell Vehicles, Chicago, IL, September 17-19, 1996.

\section{Energy Partners}

Barbir, F., "Development of PEM Fuel Cells and Vehicular Fuel Cell Systems," Proceedings of Intertech Conference on Commercializing Fuel Cell Vehicles, Chicago, IL, September 17-19, 1996.

\section{Ford Motor Company}

Oei, D-G., "Direct Hydrogen-Fueled Fuel Cells for Transportation - A Status Report," Proceedings of 1996 SAE Future Transportation Technology Conference, Vancouver, British Columbia, Canada, August 5-8, 1996.

Oei, D-G., "Direct Hydrogen-Fueled Proton-Exchange-Membrane (PEM) Fuel Cell for Light Duty Vehicles," Volume II - U.S. Department of Energy, Annual Automotive Technology Development Customers' Coordination Meeting, Dearborn, MI, October 28 - November 1, 1996.

Oei, D-G., "Direct Hydrogen-Fueled Proton-Exchange-Membrane (PEM) Fuel Cell for Transportation," Proceedings of 1995 SAE Alternative Fuels Conference, San Diego, CA, December 6-8, 1995.

\section{General Motors Corporation}

Allison Gas Turbine Division, "Research and Development of Proton Exchange Membrane Fuel Cell System for Transportation Applications, Phase I Final Report," Report No. DOE/CH/10435-02, January 1996.

Fronk, Matthew H., Martin M. Hoch, Glenn W. Skala, and Jeffrey A. Rock, Delphi Energy and Engine Management Systems, "GM/Delphi Fuel Cell Development Program," Volume I - U.S. Department of Energy, Annual Automotive Technology Development Customers ' Coordination Meeting, Dearborn, MI, October 28 - November 1, 1996.

\section{H Power Corp.}

Fisher, J., "H Power Corp.'s Fuel Cell Systems for Transportation," Proceedings of Intertech Conference on Commercializing Fuel Cell Vehicles, Chicago, IL, September 17-19, 1996.

\section{Pentastar Electronics, Inc.}

"Conceptual Design Report for a Direct Hydrogen Proton Exchange Membrane Fuel Cell for Transportation Applications," under contract DE-AC02-94CE50390, Report No. DOE/CE/50390-9, August 1996. 


\section{FUEL PROCESSORS AND STORAGE}

\section{Argonne National Laboratory}

Ahmed, S., R. Kumar, and M. Krumpelt, "Development of a Catalytic Methanol Partial Oxidation Reformer for Light-Duty Fuel Cell Vehicles," Symposium on Electrochemical Power Sources for Electric Vehicles, AIChE Annual Meeting, Miami Beach, FL, November 12-17, 1995.

Geyer, H., R. Ahluwalia, and R. Kumar, "Dynamic Response of Steam-Reformed, Methanol-Fueled, Polymer Electrolyte Fuel Cell Systems," Proceedings of the Intersociety Energy Conversion Engineering Conference, Washington, DC, August 12-15, 1996.

Krumpelt, M., S. Ahmed, and R. Kumar, "Partial Oxidation Reforming of Methanol," EPRI/GRI Fuel Cell Workshop on Fuel Cell Technology Research and Development, Tempe, AZ, April 2-3, 1996.

Kumar, R., H. Geyer, R. Ahluwalia, and M. Krumpelt, "Modeling the Methanol Steam Reformer," International Energy Agency Annex IV Annual Meeting, Ottawa, Ontario, Canada, October 5-6, 1995.

\section{Los Alamos National Laboratory}

Vanderborgh, N., "C-1 Fuels for Modern Fuel Cell Systems," Proceedings of Intertech Conference on Commercializing Fuel Cell Vehicles, Chicago, IL, September 17-19, 1996.

\section{DOE Contractors}

\section{Arthur D. Little}

Bentley, J., "Development of a Catalytic Partial Oxidation Ethanol Reformer for Fuel Cell Applications," SAE Alternative Fuels Conference \& Exposition, San Diego, CA, December 7, 1995.

Bentley, J., "Development of a Partial Oxidation Reformer for Liquid Fuels," Proceedings of the SAE Fuel Cells for Transportation TOPTEC, Alexandria, VA, April 2, 1996.

Bentley, J., "The Role of Ethanol in Fuel Cell Vehicles," World Car Conference, University of California-Riverside, January 24, 1996.

Mitchell, W. and J. Bentley, "Arthur D. Little Flexible Fuel Processor Program Overview," Volume IU.S. Department of Energy, Annual Automotive Technology Development Customers' Coordination Meeting, Dearborn, MI, October 28 - November 1, 1996.

Mitchell, W., H. Thijssen, and J. Bentley, "Development of a Catalytic Partial Oxidation Ethanol Reformer for Fuel Cell Applications," SAE Paper 952761, Society of Automotive Engineers, 1995.

\section{Directed Technologies, Inc.}

Thomas, C.E. (Sandy), Ira F. Kuhn, Jr., Brian D. James, Frank D. Lomax, Jr., and George N. Baum, "Hydrogen Infrastructure Options for Supplying Direct Hydrogen Fuel Cell Vehicles," Volume I

- U.S. Department of Energy, Annual Automotive Technology Development Customers'

Coordination Meeting, Dearborn, MI, October 28 - November 1, 1996. 


\section{Ford Motor Company}

Sims, R., "Fueling Aspects of Hydrogen Fuel Cell Powered Vehicles," Proceedings of Fuel Cells for Transportation TOPTEC: Addressing the Fuel Infrastructure Issue, Alexandria, VA, April 1-2, 1996.

\section{COMPONENTS}

\section{Department of Energy}

Gottesfeld, S., G. Halpert, and A.R. Landgrebe, eds., "Proton Conducting Membranes Fuel Cells," Vol. 95-23, The Electrochemical Society, Inc., Pennington, NJ, 1995.

Milliken, J., R. Kost, and A. Landgrebe, "The DOE Core Research Program in Fuel Cells for Transportation," Abstract of Northeast Region American Chemical Society Meeting, Rochester, NY, October 23-24, 1995.

\section{Argonne National Laboratory}

Ahluwalia, R.K., S. Ahmed, H.K. Geyer, G.L. Henriksen, M. Krumpelt, R. Kumar, and K.M. Myles, "Transportation Fuel Cell Research at Argonne National Laboratory," Volume II - U.S. Department of Energy, Annual Automotive Technology Development Customers' Coordination Meeting, Dearborn, MI, October 28 - November 1, 1996.

Zurawski, D., A. Aldykiewicz, R. Kumar, M. Krumpelt, G. Bunker, C. Segre, and E. Smotkin, "X-Ray Absorption and Electrochemical Studies of Direct Methanol Fuel Cell Catalysts," First International Conference on Synchrotron Radiation in Materials Science, Chicago, IL, July 29 August 2, 1996.

\section{Brookhaven National Laboratory}

McBreen, J. and S. Mukerjee, "In situ X-ray Absorption Studies of a Pt-Ru Electrocatalyst," J. Electrochem. Soc.142, 3399-3404, 1995.

Mukerjee, S. and J. McBreen, "Hydrogen Electrocatalysis by Carbon Supported Pt and Pt Alloys: An in-situ X-ray Absorption Study," J. Electrochem. Soc. 143, 2285-2294, 1996.

Mukerjee, S., J. McBreen, and S. Srinivasan, "An Investigation of the Electrocatalysis for Oxygen Reduction by Pt Alloys: An XRD, XAS and Electrochemical Study," Proceedings of Symposium on Oxygen Electrochemistry, R. Adzic, F.C. Anson, and Kinoshita, eds., The Electrochemical Society, Inc., Pennington, NJ, 1996, pp. 38-49.

\section{Lawrence Berkeley Laboratory}

Gasteiger, H., N. Marković, and P. Ross, Jr., "Hydrogen and Carbon Monoxide Electrooxidation on Well-Characterized Pt, Ru, and Pt-Ru; Part 2. Rotating Disk Electrode Studies of CO/H Mixtures at $62^{\circ} \mathrm{C}, "$ J. Phys. Chem. 99 (45), 16757-16767, 1995.

Gasteiger, H., N. Marković, and P. Ross, Jr., "Structural Effects in Electrocatalysis: Electrooxidation of Carbon Monoxide on $\mathrm{Pt}_{3} \mathrm{Sn}$ Single Crystal Alloy Surfaces," Catalysis Letters 36 (1-2), 1-8, 1996. 
Markovic, N., H. Gasteiger, and P. Ross, "Oxygen Reduction on Platinum Low-Index Single-Crystal Surfaces in Alkaline Solution: Rotating Ring Disk (Pt(hkl)) Studies," J. Phys. Chem. 100, 6715$6721,1996$.

Wang, K., H. Gasteiger, N. Marković, and P. Ross, Jr., "On the Reaction Pathway for Methanol and Carbon Monoxide Electrooxidation on Pt-Sn Alloy Versus Pt-Ru Alloy Surfaces," Electrochimica Acta 41, 2587-2593, 1996.

\section{Los Alamos National Laboratory}

Ren, Xiaoming, Tom Springer, Mahlon Wilson, Tom Zawodzinski, Chuck Derouin, Judith Valerio, Mike Inbody, Nick Vanderborgh, and Shimson Gottesfeld, "The Fuel Cell Core Research Program at LANL," Volume II - U.S. Department of Energy, Annual Automotive Technology Development Customers' Coordination Meeting, Dearborn, MI, October 28 - November 1, 1996.

Ren, X., M. Wilson, and S. Gottesfeld, "High Performance Direct Methanol Polymer Electrolyte Fuel Cells," J. Electrochem. Soc. 143, L12-L15, 1996.

Springer, T., T. Zawodzinski, M. Wilson, and S. Gottesfeld, "Characterization of Polymer Electrolyte Fuel Cells Using AC Impedance Spectroscopy," J. Electrochem. Soc. 143, 587-599, 1996.

\section{Pacific Northwest Laboratory}

Wegeng, R., "Microchannel Fuel Processor Components," DOE Fuel Cells for Transportation Exploratory R\&D Program Review, Washington, DC, September 25-26, 1996.

\section{Sandia National Laboratories}

Gardner, T., "Hydrogen Purification with Ceramic Membranes for Fuel Cell Applications," DOE Fuel Cells for Transportation - Exploratory R\&D Program Review, Washington, DC, September 2526, 1996.

\section{DOE Contractors}

\section{AlliedSignal}

Morasko, Gwyn and Luis Pascual, "Design to Cost Direct Hydrogen PEM Fuel Cell Development," Volume II - U.S. Department of Energy, Annual Automotive Technology Development Customers ' Coordination Meeting, Dearborn, MI, October 28 - November 1, 1996.

\section{Energy Partners, Inc.}

Barbir, F., M. Graham, and R. Ross, "Development of Advanced PEM Fuel Cells for Transportation Applications," Volume II - U.S. Department of Energy, Annual Automotive Technology Development Customers' Coordination Meeting, Dearborn, MI, October 28 - November 1, 1996.

\section{International Fuel Cells Corporation}

Meyer, A.P., "50-kW Ambient Pressure PEM Fuel Cell Power Plant Development," Volume I - U.S. Department of Energy, Annual Automotive Technology Development Customers ' Coordination Meeting, Dearborn, MI, October 28 - November 1, 1996. 
Mechanical Technology, Inc.

Ernst, William D., "PEM Fuel Cell Stack Development for Automotive Applications," Volume II - U.S. Department of Energy, Annual Automotive Technology Development Customers ' Coordination Meeting, Dearborn, MI, October 28 - November 1, 1996.

\section{Vairex Corporation}

Cronin, Jeremiah J., "Advanced Compressors and Expanders for Fuel Cell Applications," Volume II U.S. Department of Energy, Annual Automotive Technology Development Customers'

Coordination Meeting, Dearborn, MI, October 28 - November 1, 1996.

\section{Texas A\&M University System}

Appleby, A.J., Omourtag A. Velev, Serguey Gamburzev, and Supramaniam Srinivasan, "Low-Cost, Light-Weight, Internal Humidified PEM Fuel Cell," Volume II - U.S. Department of Energy, Annual Automotive Technology Development Customers' Coordination Meeting, Dearborn, MI, October 28 - November 1, 1996.

\subsection{AUTOMOTIVE MATERIALS}

\section{GENERAL - OVERVIEW}

Dinda, S., Chrysler Corporation, "Materials Requirements for Advanced Automobiles," Volume I - U.S. Department of Energy, Annual Automotive Technology Development Customers' Coordination Meeting, Dearborn, MI, October 28 - November 1, 1996.

Haught, D., U.S. Department of Energy, "Automotive Propulsion Materials," Volume I - U.S. Department of Energy, Annual Automotive Technology Development Customers' Coordination Meeting, Dearborn, MI, October 28 - November 1, 1996.

Maréchaux, T.G., U.S. Department of Energy, "Lightweight Vehicle Materials," Volume I - U.S. Department of Energy, Annual Automotive Technology Development Customers' Coordination Meeting, Dearborn, MI, October 28 - November 1, 1996.

Sherman, A.M., Ford Motor Company, "Challenges and Opportunities for Advanced Automotive Materials," Volume I - U.S. Department of Energy, Annual Automotive Technology Development Customers' Coordination Meeting, Dearborn, MI, October 28 - November 1, 1996.

\section{LIGHTWEIGHT BODY, CHASSIS, AND ENGINE MATERIALS}

\section{ORNL - Durability Project}

Corum, J.M., "Durability of a Continuous Strand Mat Polymeric Composite for Automotive Structural Applications," Proceedings of Advanced Composites Conference and Exposition, November 6-9, 1995, pp. 407-418.

Corum, J.M., et al., "Durability of Composites in Automotive Structural Applications," Volume II - U.S. Department of Energy, Annual Automotive Technology Development Customers' Coordination Meeting, Dearborn, MI, October 28 - November 1, 1996. 
Herring, H.M., et al., "A Study of the Effects of Chemical Environments on the Mechanical Properties of Swirl Glass Mat Reinforced Polyurethane Composite," Proceedings of the ASME Materials Division, MD-Vol. 69-1, 1995 ASME International Mechanical Engineering Congress and Exposition, November 1995.

Worley II, D.C., et al., "Microscopy and Ultrasound as an NDT Technique for Polymer Composites," P.K. Liaw, et al., eds., TMS Fall Meeting, Cincinnati, OH, October 6-10, 1996.

\section{INEL - Slurry Processing for Glass Fiber Preforms}

Johnson, R.W. and M.D. Landon, "Simulation and Optimization of a Slurry-Based Fiberglass Preform Manufacturing Process," Proceedings of the 11th Annual ASMIESD Advanced Composites Conference and Exposition, ASM International, 1995, pp. 233-245.

Moore, G.A. and R.W. Johnson, "Slurry Preforming Methods for Automotive Polymer Composites," Volume II - U.S. Department of Energy, Annual Automotive Technology Development Customers' Coordination Meeting, Dearborn, MI, October 28 - November 1, 1996.

Moore, G.A., R.W. Johnson, M.D. Landon, C.A. Stoots, and J.L. Anderson, "Slurry Based Fabrication of Chopped Fiberglass Composite Preforms," Proceedings of the 41 st International SAMPE Symposium, 41, March 24-28, 1996, pp. 510-519.

\section{University of Texas - Modeling of Fracture in Bonded Joints}

Shah, J.H. and K.M. Liechti, "Mixed-Mode Resistance Curve Behavior of Structural Adhesively Bonded Joints," 1996 ASME Mechanics and Materials Conference Abstracts, Johns Hopkins University, p. 164.

\section{ORNL - Adhesive Bonding Project}

Boeman, R.G. and C.D. Warren, "Fracture Testing and Analysis of Adhesively Bonded Joints for Automotive Applications," Proceedings of the 10th Annual ASM/ESD Advanced Composites Conference, Dearborn, MI, pp. 473-481.

Boeman, R.G., D.L. Erdman, L.B. Klett, and F.L. Paulauskas, "Adhesive Bonding for Automotive Applications," Volume II - U.S. Department of Energy, Annual Automotive Technology Development Customers' Coordination Meeting, Dearborn, MI, October 28 - November 1, 1996.

Paulauskas, F.L., A.D. McMillan, and C.D. Warren, "Adhesive Bonding Via Exposure to Variable Frequency Microwave Radiation," Proceedings of the Spring Materials Research Society (MRS), San Francisco, CA, April 8-12, 1996.

Paulauskas, F.L., T.T. Meek, and C.D. Warren, "Adhesive Bonding Via Exposure to Microwave Radiation and Resulting Mechanical Evaluation," Proceedings of the Spring Materials Research Society (MRS), San Francisco, CA, April 8-12, 1996.

Paulauskas, F.L, C.D. Warren, and T.T. Meek, "Adhesive Bonding/Joining Via Exposure to Microwave . Radiation," Proceedings of the 27th International SAMPE Technical Conference, Albuquerque, NM, October 9-12, 1995. 


\section{Oakland University - Laser Shearography for Full-Field NDT of Composites}

Hung, Y.Y., "Computerized Shearography and Its Application for Nondestructive Testing of Composites," Manual on Experimental Methods for Mechanical Testing of Composites, Society of Experimental Mechanics.

Hung, Y.Y., "Shearography and Application in Experimental Mechanics," Keynote Paper, International Conference on Experimental Mechanics, December 4-6, 1996, Singapore.

\section{Other Publications}

Baldwin, Mike and Mike Maguire, Sandia National Laboratories, "Rapid Tooling for Functional Prototyping of Metal Mold Processes," Volume II - U.S. Department of Energy, Annual Automotive Technology Development Customers' Coordination Meeting, Dearborn, MI, October 28 - November 1, 1996.

Schneider, Art, et al., U.S. Automotive Materials Partnership, "Design \& Product Optimization for Cast Light Metals," Volume II - U.S. Department of Energy, Annual Automotive Technology

Development Customers ' Coordination Meeting, Dearborn, MI, October 28 - November 1, 1996.

\section{PROPULSION SYSTEM MATERIALS}

Brinkman, C.R., et al., Oak Ridge National Laboratory, "Life Prediction Codes for Use of Ceramics in Automotive Engines," Volume II - U.S. Department of Energy, Annual Automotive Technology Development Customers' Coordination Meeting, Dearborn, MI, October 28 - November 1, 1996.

Carruthers, Dave, et al., Kyocera Industrial Ceramics Corp., "Ceramic Components for Advanced Automotive Applications," Volume II - U.S. Department of Energy, Annual Automotive Technology Development Customers ' Coordination Meeting, Dearborn, MI, October 28 November 1, 1996.

Choi, S.R. and J.A. Salem, "Cyclic Fatigue of Brittle Materials with an Indentation-Induced Flaw System," Mat. Sci. Eng., 1996.

Choi, S.R. and J.A. Salem, "Free Rollers vs Fixed Rollers in Flexure Testing of Ceramic Materials," Paper No. C-98-96F, 1996 Conference \& Exposition on Composites, Ceramics, Materials and Structures (American Ceramic Society), Cocoa Beach, FL, January 7-11, 1996. (Also published in Ceram. Eng. Sci. Proc., November 1996.)

Choi, S. R. and J.A. Salem, "Inert Strength of Advanced Ceramic Materials at Elevated Temperatures," Paper No. C-87-96F, 1996 Conference \& Exposition on Composites, Ceramics, Materials and Structures (American Ceramic Society), Cocoa Beach, FL, January 7-11, 1996. (Also published in Ceram. Eng. Sci. Proc., November 1996.)

Choi, S.R. and J.A. Salem, "Preloading Technique in Dynamic Fatigue Testing of Glass and Ceramics with an Indentation Flaw System," J. Am. Ceram. Soc. 79 (5), 1228-32, 1996.

Ding, J.L., K.C. Liu, and C.R. Brinkman, “A Multiaxial Viscoplastic Model for Advanced $\mathrm{Si}_{3} \mathrm{~N}_{4}$ Ceramics," Paper No. C-17-96F, 1996 Conference \& Exposition on Composites, Ceramics, Materials and Structures (American Ceramic Society), Cocoa Beach, FL, January 7-11, 1996. (Also published in Ceram. Eng. Sci. Proc., November 1996.) 
Draskovich, Barry, et al., AlliedSignal Engines, "AlliedSignal Ceramic Components Cost Effective Ceramics," Volume II - U.S. Department of Energy, Annual Automotive Technology Development Customers' Coordination Meeting, Dearborn, MI, October 28 - November 1, 1996.

Huang, Z.K. and T.Y. Tien, "Solid-Liquid Reaction in the $\mathrm{Si}_{3} \mathrm{~N}_{4}-\mathrm{AlN}-\mathrm{Y}_{2} \mathrm{O}_{3}$ System Under $1 \mathrm{MPa}$ of Nitrogen," J. Am. Ceram. Soc. 79 (6), 1717-1719, 1996.

Lee, W.Y., Y.W. Bae, D.P. Stinton, and K.L. More, "Characterization of $\mathrm{Si}_{3} \mathrm{~N}_{4}$ Protected with CVD Mullite Coating from $\mathrm{Na}_{2} \mathrm{SO}_{4}$ Induced Corrosion," Paper No. C-83-96F, 1996 Conference \& Exposition on Composites, Ceramics, Materials and Structures (American Ceramic Society), Cocoa Beach, FL, January 7-11, 1996. (Also published in Ceram. Eng. Sci. Proc., November 1996.)

Lee, W.Y., K.L. More, D.P. Stinton, and Y. Bae, "Characterization of $\mathrm{Si}_{3} \mathrm{~N}_{4}$ Coated with Chemically Vapor Deposited Mullite after $\mathrm{Na}_{2} \mathrm{SO}_{4}$ Induced Corrosion," J. Am. Ceram. Soc. 79 (9), 24892492, 1996.

Lee, W.Y., D.P. Stinton, and D.L. Joslin, "Interaction of Low-Expansion Ceramics with $\mathrm{Na}_{2} \mathrm{SO}_{4}$ at 1000 C," J. Am. Ceram. Soc. 79, 484, 1996.

Lin, H.T., "Environmental Effect on Creep of Gas Pressure Sintered Silicon Nitride," Paper No. SXIV-5, 98th Annual Meeting and Exposition of the American Ceramic Society, Indianapolis, IN, April 14-17, 1996.

Lin, H.T., K.A. Alexander, and P.F. Becher, "Grain Size Effect on Creep Deformation of Alumina-SiC Composites," J. Am. Ceram. Soc.

Liu, K.C., C.O. Stevens, and C.R. Brinkman, "A Technique to Achieve Uniform Stress Distribution in Compressive Creep Testing of Advanced Ceramics at High Temperatures," Paper No. 96-GT341, 41st ASME Gas Turbine and Aeroengine Congress, Birmingham, UK, June 10-13, 1996.

Liu, K.C., C.O. Stevens, C.R. Brinkman, K.L. More, J.O. Kiggans, and T.N. Tiegs, "The Influence of Heat Treatments on Creep Behavior of a Sintered $\mathrm{Si}_{3} \mathrm{~N}_{4}$ Ceramic," Paper No. C-82-96F, 1996 Conference \& Exposition on Composites, Ceramics, Materials and Structures (American Ceramic Society), Cocoa Beach, FL, January 7-11, 1996. (Also published in Ceram. Eng. Sci. Proc., November 1996.)

Nunn, S.D., "Green Machining of Gelcast Ceramic Materials," Paper No. C-108-96F, 1996 Conference \& Exposition on Composites, Ceramics, Materials and Structures (American Ceramic Society), Cocoa Beach, FL, January 7-11, 1996. (Also published in Ceram. Eng. Sci. Proc., November 1996.)

Omatete, O.O., et al., Oak Ridge National Laboratory "Manufacturability of Gelcast Ceramics for Advanced Heat/Gas Turbine Engines," Volume II - U.S. Department of Energy, Annual Automotive Technology Development Customers ' Coordination Meeting, Dearborn, MI, October 28 - November 1, 1996.

Peterson, I.M. and T.Y. Tien, "Effect of Grain Boundary Thermal Expansion Coefficient on the Fracture Toughness in Silicon Nitride," J. Am. Ceram. Soc.78 (9), 2345-2352, 1996. 
Wu, K.H., K.C. Liu, and M.L. Santella, "Indentation Fracture Assessment of Residual Stress in $\mathrm{Si}_{3} \mathrm{~N}_{4}$," Paper No. C-96-96F, 1996 Conference \& Exposition on Composites, Ceramics, Materials and Structures (American Ceramic Society), Cocoa Beach, FL, January 7-11, 1996. (Also published in Ceram. Eng. Sci. Proc., November 1996.)

\subsection{ALTERNATIVE FUELS}

\section{COMPRESSED NATURAL GAS}

Wozniak, J.J., Johns Hopkins University, “Advanced Natural Gas Vehicle Program,” Volume II - U.S. Department of Energy, Annual Automotive Technology Development Customers' Coordination Meeting, Dearborn, MI, October 28 - November 1, 1996.

\section{ETHANOL}

Arthur D. Little, Inc., "Partial Oxidation for Improved Cold-Start in Alcohol-Fueled Engines," Phase I Topical Report, National Renewable Energy Laboratory Subcontract No. YCC-5-14050-01, December 1996.

Balles, E.N., P.J. Loftur, and K. Drobot, Arthur D. Little, Inc., "Partial Oxidation for Improved ColdStart in Alcohol Fueled Engines," Phase I Report (Draft), National Renewable Energy Laboratory Subcontract No. YCC-5-14050-01, September 1996.

Burch, S.D., M.A. Keyser, C.P. Colucci, T.F. Potter, and D.K. Benson, National Renewable Energy Laboratory; J.P. Biel, Benteler Industries, Inc., "Applications and Benefits of Catalytic Converter Thermal Management," SAE Paper 961134, SAE International Spring Fuels \& Lubricants Meeting, Dearborn, MI, May 6-8, 1996.

Dodge, L.G., et al., Southwest Research Institute, "Development of Dedicated Ethanol Ultra-Low Emission Vehicle (ULEV)," National Corn Grower's Association Corn Utilization Conference, St. Louis, MO, June 6, 1996.

Dodge, L.G., T.J. Callahan, D.M. Leone, D.W. Naegeli, K.R. Shouse, L.R. Smith, and K.A. Whitney, Southwest Research Institute, "Development of a Dedicated Ethanol Ultra-Low Emission Vehicle (ULEV)," Phase 3 Report, National Renewable Energy Laboratory Subcontract No. YAW-3-12243-01, September 1996.

Drobot, K., P.J. Loftus, and E.N. Balles, Arthur D. Little, Inc., "Partial Oxidation for Improved ColdStart in Alcohol-Fueled Engines," Volume II - U.S. Department of Energy, Annual Automotive Technology Development Customers' Coordination Meeting, Dearborn, MI, October 28 November 1, 1996.

Hodgson, J. and D. Irick, The University of Tennessee, "Investigation and Demonstration of a Rich Combustor Cold-Start Device for Alcohol-Fueled Engines," Volume II - U.S. Department of Energy, Annual Automotive Technology Development Customers ' Coordination Meeting, Dearborn, MI, October 28 - November 1, 1996.

Keyser, M.A., S.D. Burch, and D.K. Benson, National Renewable Energy Laboratory, "The Thermal Management of an Ethanol Fueled Ford Taurus Catalytic Converter," Oral Presentation, Windsor Workshop, Toronto, Ontario, Canada, June 4, 1996. 
Kito, T., J. Wittayakum, D. Pacus, S. Selim, and S.W. Cowley, Colorado School of Mines, "The Catalytic Dissociation or Dehydration of Ethanol for On-board Cold Start Assistance,"

Proceedings of the Eleventh International Symposium on Alcohol Fuels, Vol. I, pp. 166-177, Sun City, South Africa, April 14-17, 1996.

Thring, R.H. and L.G. Dodge, Southwest Research Institute, "Development of a Dedicated Ethanol UltraLow Emission Vehicle (ULEV)," Volume II - U.S. Department of Energy, Annual Automotive Technology Development Customers' Coordination Meeting, Dearborn, MI, October 28 -

November 1, 1996.

\section{LIQUEFIED PETROLEUM GAS}

Kunz, R.K., M.D. Blair, M.J. Warner, and R.P. Graham, Thiokol Corporation, "Conformable Pressurized Fuel Storage for Increased Vehicle Range," SAE Paper 961673, 1996 SAE Future

Transportation Technology Conference, Vancouver, British Columbia, Canada, August 6, 1996.

Smith, D. and T. Standke, IMPCO Technologies, "Development of a Dedicated LPG Ultra-Low Emission Vehicle," Volume II - U.S. Department of Energy, Annual Automotive Technology Development Customers' Coordination Meeting, Dearborn, MI, October 28 - November 1, 1996.

\section{HYDROGEN}

Swain, M.R., M.N. Swain, and G.J. Schade, University of Miami, "Design and Testing of a Dedicated Hydrogen Fueled Engine," SAE Paper 961077, SAE International Fuels \& Lubricants Meeting, Dearborn, MI, May 6-8, 1996.

\section{GENERAL ALTERNATIVE FUELS TECHNOLOGY}

Argonne National Laboratory, Evaluation of Oxygen-Enrichment System for Alternative Fuel Vehicles Final Report, National Renewable Energy Laboratory Subcontract No. DAW-4-13516-01.

Bailey, B. and C. Colucci, National Renewable Energy Laboratory, "R\&D on the Utilization of Alcohol Fuels at the National Renewable Energy Laboratory," World Renewable Energy Congress IV, Denver, CO, June 20, 1996.

Bailey, B. and C. Colucci, National Renewable Energy Laboratory, "Research and Development on the Utilization of Alcohol Fuels at the National Renewable Energy Laboratory," Renewable Energy, Vol. 10, No. 2/3, pp. 273-278.

Bailey, B., C. Colucci, and M. Bergin, National Renewable Energy Laboratory; T. Timbario, EA Consulting Engineers; "U.S. Department of Energy Research and Development on the Utilization of Alcohol Fuels," Proceedings of the Eleventh International Symposium on Alcohol Fuels, Vol. I, pp. 178-189, Sun City, South Africa, April 14-17, 1997.

Barker, Thomas D., Ford Motor Company/AAMA, "Automotive Alternative Fuels R\&D Challenges and Opportunities," Volume I - U.S. Department of Energy, Annual Automotive Technology Development Customers' Coordination Meeting, Dearborn, MI, October 28 - November 1, 1996.

Barnes, Gerald, J., General Motors Corporation/American Automobile Manufacturers Association, "Automotive Alternative Fuels R\&D: Barriers and Needs of Alcohol Fuels," Volume I - U.S. Department of Energy, Annual Automotive Technology Development Customers' Coordination Meeting, Dearborn, Mị, October 28 - November 1, 1996. 
Garbak, John A., U.S. Department of Energy, "The Department of Energy's Automotive Alternative Fuels R\&D Program," Volume I - U.S. Department of Energy, Annual Automotive Technology Development Customers ' Coordination Meeting, Dearborn, MI, October 28 - November 1, 1996.

Maloney, Fred, Chrysler Corporation/American Automobile Manufacturers Association, "Automotive Alternative Fuels R\&D: Barriers and Needs of Compressed Natural Gas and Propane," Volume I - U.S. Department of Energy, Annual Automotive Technology Development Customers' Coordination Meeting, Dearborn, MI, October 28 - November 1, 1996.

Poola, R.B., H.K. Ng, and R. Sekar, Argonne National Laboratory; J.H. Baundino, AutoResearch Laboratory, Inc.; C.P. Colucci, National Renewable Energy Laboratory; "The Effects of OxygenEnriched Intake Air on FEV Exhaust Emissions Using M85 Fuel," SAE Paper 961171, SAE International Spring Fuels \& Lubricants Meeting, Dearborn, MI, May 7, 1996. 


\section{APPENDIX C}

\section{LIST OF ABBREVIATIONS AND ACRONYMS}

ADL Arthur D. Little, Inc.

AFV alternative fuel vehicle

AGATA Advanced Gas Turbine for Automobiles

AGT Advanced Gas Turbine

ANL Argonne National Laboratory

ATTAP Advanced Turbine Technology Applications Project

BNL Brookhaven National Laboratory

CAFE Corporate Average Fuel Economy

CARB California Air Resources Board

CFD computational fluid dynamics

CFR Code of Federal Regulations

CIDI compression-ignition, direct-injection

CNG compressed natural gas

$\mathrm{CO}$ carbon monoxide

CRADA Cooperative Research and Development Agreement

CVT continuously variable transmission

DARPA Defense Advanced Research Projects Agency

DME dimethyl ether

DOC Department of Commerce

DOE U.S. Department of Energy

ECM Electronic Control Module

EDU Electric Drive Unit

EH\&S Environmental, Health, and Safety

EIA Energy Information Administration

EMI electromagnetic interference

EPA Environmental Protection Agency

EPS Electric Power Steering

EPACT Energy Policy Act of 1992

EPRI Electric Power Research Institute

ESS Energy Storage System

ESST Engine Support System Technology

EUCAR European Council for Automotive Research and Development 
EZEV Equivalent Zero-Emission Vehicle

FCV fuel cell vehicle

FTP Federal Test Procedure

FUDS Federal Urban Driving Schedule

GT-HPU gas turbine hybrid power unit

HC hydrocarbons

HEV hybrid electric vehicle

HPU Hybrid Power Unit

HWFET Highway Fuel Economy Test

ICE internal combustion engine

IFC International Fuel Cells

IGBT insulated gate bipolar transistor

IGT Institute of Gas Technology

INEL Idaho National Engineering Laboratory

ISS Integrated Storage System

IWC Infrastructure Working Council

LANL Los Alamos National Laboratory

LBNL Lawrence Berkeley National Laboratory

LEP Low Emission Partnership

LEV Low-Emission Vehicle

LLNL Lawrence Livermore National Laboratory

LPG liquefied petroleum gas

LSR Low Storage Requirement

MITI Ministry of International Trade and Industry

MRI Midwest Research Institute

NASA National Aeronautics and Space Administration

NDE non-destructive evaluation

NEC National Electrical Code

NOx oxides of nitrogen

NREL National Renewable Energy Laboratory

OAAT Office of Advanced Automotive Technologies

OEM original equipment manufacturer

ONR Office of Naval Research

ORNL Oak Ridge National Laboratory

OTT Office of Transportation Technologies

PEB Power Electronics Bay 
PEBB Power Electronic Building Block

PEM proton-exchange-membrane

PM particulate matter

PNGV Partnership for a New Generation of Vehicles

PNNL Pacific Northwest National Laboratory

POX partial oxidation

PTH Post Transmission Hybrid

SAE Society of Automotive Engineers

SI spark ignition

SNL Sandia National Laboratories

SOC state-of-charge

SwRI Southwest Research Institute

TACOM Tank-automotive and Armaments Command

ULEV Ultra-Low-Emission Vehicle

USABC U.S. Advanced Battery Consortium

USCAR U.S. Council for Automotive Research

USAMP U.S. Automotive Materials Partnership

XAS X-ray absorption spectroscopy

ZEBRA Zero Emission Battery Research Activity

ZEV Zero-Emission Vehicle 